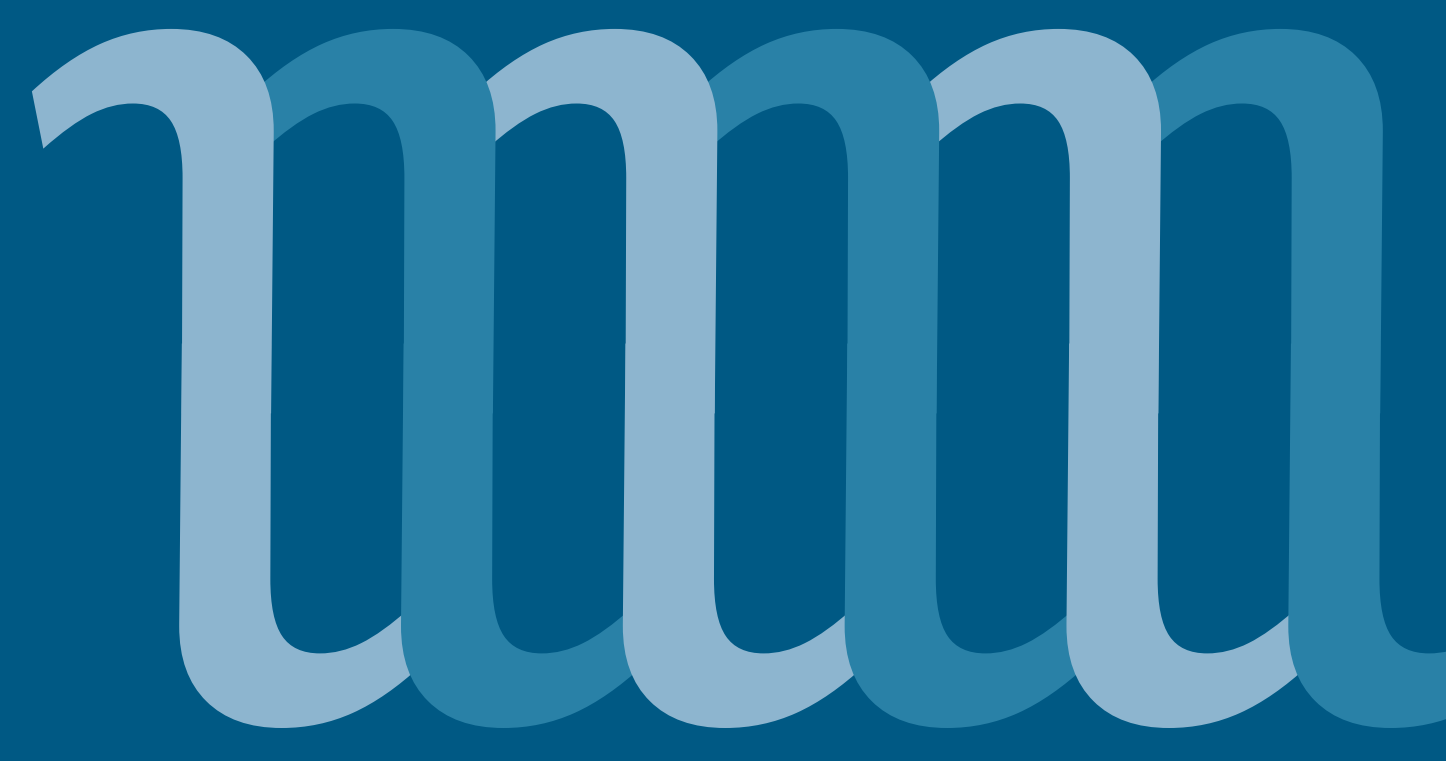

\title{
Razširjenost piratstva programske opreme med študenti
}

Sergej Iskra

Viktorija Florjančič 
Znanstvene monografije

Fakultete za management

Glavni urednik

Matjaž Novak

Uredniški odbor

Ana Arzenšek

Štefan Bojnec

Dubravka Celinšek

Armand Faganel

Viktorija Florjančič

Borut Kodrič

Suzana Laporšek

Mirko Markič

Franko Milost

Matjaž Nahtigal

Mitja Ruzzier

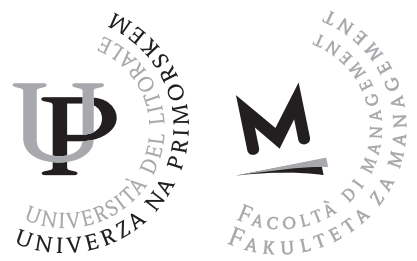




\section{Razširjenost piratstva programske opreme med študenti}

Sergej Iskra

Viktorija Florjančič

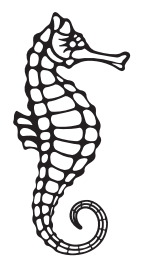


Razširjenost piratstva programske opreme med študenti

Sergej Iskra in Viktorija Florjančič

Recenzenta $\cdot$ Andrej Brodnik in Benjamin Lesjak

Lektoriranje · Davorin Dukić

Oblikovanje in tehnična ureditev · Alen Ježovnik

Izdala in založila $\cdot$ Založba Univerze na Primorskem

Titov trg 4, 6ooo Koper

www.hippocampus.si

Glavni urednik · Jonatan Vinkler

Vodja založbe · Alen Ježovnik

Koper, februar 2018

(C) 2018 Sašo Stanojev in Viktorija Florjančič

http://www.hippocampus.si/ISBN/978-961-7023-84-8.pdf

http://www.hippocampus.si/ISBN/978-961-7023-85-5/index.html

https://doi.org/10.26493/978-961-7023-84-8

\section{(9) (1) $(\Theta \Theta$}

Kataložni zapis o publikaciji (CIP) pripravili

v Narodni in univerzitetni knjižnici v Ljubljani

COBISS.SI-ID $=294035456$

IS B N 978-961-7023-84-8 (pdf)

IS B N 978-961-7023-85-5 (html) 


\section{Kazalo}

Seznam preglednic $\cdot 6$

Seznam slik $\cdot 8$

Krajšave $\cdot 9$

$1 \mathrm{Uvod} \cdot 11$

2 Piratstvo $\cdot 15$

2.1 Splošno o piratstvu $\cdot 15$

2.2 Pravna ureditev avtorskih pravic $\cdot 18$

2.3 Vrste piratstva $\cdot 30$

2.4 Vzroki za povpraševanje po piratski programski opremi $\cdot 42$

2.5 Vzroki za ponudbo piratske programske opreme 49

2.6 Možnosti za zmanjšanje stopnje piratstva $\cdot 51$

3 Brezplačna in odprtokodna programska oprema $\cdot 59$

3.1 Licence 60

3.2 Značilnosti OPO $\cdot 62$

3.3 Prednosti in slabosti OPO 63

3.4 OPO kot alternativa komercialni programski opremi $\cdot 64$

3.5 Financiranje OPO $\cdot 66$

4 Piratstvo programske opreme - raziskava $\cdot 69$

4.1 Potek raziskave in predstavitev vzorca $\cdot 69$

4.2 Analiza anketnih vprašalnikov $\cdot 71$

4.3 Preverjanje hipotez $\cdot 93$

5 Sklep 99

Literatura $\cdot 103$

Priloge $\cdot 109$ 


\section{Seznam preglednic}

2.1 Dejavniki povpraševanja po piratski programski opremi $\cdot 43$

2.2 Dejavniki ponudbe po piratski programski opremi $\cdot 52$

3.1 Primerjava komercialne programske opreme in O P O 66

4.1 Delež odgovorov glede na stopnjo študija po preučevanih državah · 70

4.2 Delež odgovorov glede na spol po preučevanih državah $\cdot 71$

4.3 Ocena IKT-pismenosti anketirancev $\cdot 72$

4.4 Način pridobitve programske opreme $\cdot 73$

4.5 Korelacijska analiza načina pridobitve programske opreme $\cdot 73$

4.6 Nameščenost programske opreme $\cdot 75$

4.7 Rangi po spolu $\cdot 76$

4.8 Rangi po študijskem programu $\cdot 77$

4.9 Rangi po državah prebivanja $\cdot 78$

4.10 Man-Whitneyjev U-test (Slovenija, Velika Britanija) · 78

4.11 Man-Whitneyjev U-test (Slovenija, Srbija) 78

4.12 Man-Whitneyjev U-test (Slovenija, Poljska) $\cdot 78$

4.13 Korelacijska matrika $\cdot 79$

4.14 Koeficienti · 80

4.15 Rezultati regresijske analize $\cdot 80$

4.16 Dejavniki uporabe piratske programske opreme $\cdot 81$

4.17 Dejavniki zmanjševanja uporabe piratske programske opreme $\cdot 82$

4.18 Ocena komunalitet dejavnikov uporabe piratske programske opreme $\cdot 84$

4.19 Celotna pojasnjena varianca $\cdot 84$

4.20 Pojasnjena varianca po rotaciji $\cdot 85$

4.21 Faktorska struktura dejavnikov po rotaciji faktorjev $\cdot 85$

4.22 Primerjani dejavniki uporabe piratske programske opreme $\cdot 87$

4.23 Nadomeščanje programske opreme z O P O $\cdot 88$

4.24 Nadomeščanje programske opreme z O P O 88

4.25 Dejavniki, ki vplivajo na nadomeščanje komercialne P O $\mathrm{z}$ OPO in BPO 89

4.26 Ocena komunalitet dejavnikov nadomeščanja programske opreme $\cdot 90$

4.27 Celotna pojasnjena varianca $\cdot 91$

4.28 Pojasnjena varianca po rotaciji $\cdot 91$ 


\section{Seznam preglednic}

4.29 Faktorska struktura dejavnikov po rotaciji faktorjev $\cdot 92$

4.30 Nameščenost piratske programske opreme in I K T-pismenost · 94

4.31 Rangi po IK T-pismenosti $\cdot 94$

4.32 Testne statistike $\cdot 94$

4.33 Rezultati regresijske analize $\cdot 95$

4.34 Nameščenost piratske programske opreme in B D P na prebivalca 96

4.35 Rangi po B D P na prebivalca 97

4.36 Testne statistike: stopnja nameščenosti piratske programske opreme $\cdot 97$

4.37 Korelacijska matrika $\cdot 98$

5.1 Obravnavane hipoteze $\cdot 101$ 


\section{Seznam slik}

2.1 Piramida internetnega piratstva $\cdot 36$

2.2 Shema omrežja odjemalec - strežnik $\cdot 38$

2.3 Shema omrežja Napster $\cdot 40$

2.4 Shema čistega omrežja P 2 P 41

2.5 Shema naprednega hibridnega omrežja $\cdot 42$

2.6 Dejavniki vpliva na odločitev o pridobivanju programske opreme 50

3.1 Kategorije programske opreme po merilih GNU $\cdot 61$ 


\section{Krajšave}

B B S Bulletin Board System

B P O Brezplačna programska oprema

B S A Business Software Alliance

CAS Copyright Alert System

C C P R The Copyright (Computer Programs) Regulations

CDPA Copyright, Designs and Patents Act

CPS The Crown Prosecution Service

CRRR The Copyright and Related Rights Regulations

Dos Department of State

D R M Digital Rights Management

D T R S Državno tožilstvo Republike Slovenije

E C European Commision

F T P File Transfer Protocol

F S F Free Software Foundation

H A D O P I Haute Autorité pour la Diffusion des œuvres et la protection des droits d'auteur sur Internet

IP Internet Protocol

I PA A International Intellectual Property Alliance

I R C Internet Relay Chat

IS P Internet Service Provider

KZ-1 Kazenski zakonik

MPAA Motion Picture Association of America

o P o Odprtokodna programska oprema

o s I Open Source Innitiative

P-ZAS P Zakon o avtorski in sorodnih pravicah Republike Poljske

P 2 P Peer-to-Peer

S U R S Statistični urad Republike Slovenije

TI RS Tržni inšpektorat Republike Slovenije

TOR The Onion Router

T P B Theory of Planed Behaviour

VP N Virtual Private Network 
WI P O World Intellectual Property Organization

ZAIS P Zakon o autorskim i surodnim pravima

ZASP Zakon o avtorski in sorodnih pravicah 


\section{Uvod}

Zakon o avtorski in sorodnih pravicah ( $\mathrm{Z} \mathrm{A} \mathrm{S} \mathrm{P})^{1}$ v 5. členu avtorska dela opredeli kot »individualne intelektualne stvaritve s področja književnosti, znanosti in umetnosti, ki so na kakršen koli način izražene«; med njimi kot avtorsko delo $\mathrm{v}$ drugem odstavku opredeljuje tudi računalniške programe.

Za računalniške programe, ki so avtorsko zaščiteni, veljajo predvsem naslednje avtorske pravice (Tržni inšpektorat Republike Slovenije 2014):

- pravica reproduciranja, ki določa pogoje, pod katerimi se računalniški program lahko shranjuje in kopira;

- pravica distribuiranja, ki določa, kako se računalniški program lahko prodaja oziroma prenaša med uporabniki;

- pravica dajanja v najem, ki avtorju podeljuje pravico, da računalniški program daje v najem.

Nepooblaščeno kopiranje in/ali prenašanje avtorsko zaščitene programske opreme B S A opredeljuje kot piratstvo programske opreme. Pri tem ni mišljeno le kopiranje tovrstne opreme, ampak tudi nameščanje opreme na več računalnikov, če to ni dovoljeno z licenco. ${ }^{2}$ Podobno piratstvo programske opreme opredelita tudi Moores in Dhilon (2000).

V letu 2013 je Tržni inšpektorat R S izvedel pregled v povezavi z ugotavljanjem kršitev avtorskih pravic na področju računalništva pri 59 gospodarskih subjektih, pri čemer je bilo evidentiranih 1.820 računalniških programov. Izmed pregledanih programov posamezni subjekti niso mogli dokazati zakonite uporabe za 11,2 \% programov, pri čemer je pri 59 pregledanih pravnih osebah zakon kršilo 57,6\% pravnih oseb, in sicer v povezavi $z$ vsaj enim računalniškim programom (Tržni inšpektorat Republike Slovenije 2014).

\footnotetext{
${ }^{1}$ Uradni list Republike Slovenije, št. 21/95, 9/o1, 30/o1 - ZC U K P I L, 43/o4, 17/o6, 139/o6, $68 / 08,110 / 13$ in 56/15.

${ }^{2}$ Glej http://ww2.bsa.org/country.aspx?sc_lang=\%sl-s I.
} 
Novos in Waldman (2013) izjemno rast digitalnega piratstva v zadnjih desetletjih vidita predvsem $v$ tehnološkem napredku, ki omogoča visoko kakovost kopiranih vsebin (kopija je dejansko enaka izvirniku) ter nizke stroške izdelave, hranjenja in distribucije piratskih kopij.

Organizacija BS A (Business Software Alliance) ocenjuje, da je bilo v Republiki Sloveniji leta 2013 45\% vse nameščene programske opreme piratskega izvora (B S A 2014). Študija pa ugotavlja tudi, da se je od leta 2007 ta stopnja znižala za tri odstotne točke. Študija B S A ocenjuje, da je stopnja nameščene piratske programske opreme v Veliki Britaniji 24\%, na Poljskem $51 \%$ in v Srbiji $67 \%$, pri čemer iz iste študije izhaja, da je v Veliki Britaniji stopnja piratstva od leta 2007 ostala na enaki ravni, na Poljskem se je znižala za šest odstotnih točk, v Srbiji pa za sedem odstotnih točk (B S A 2014). Razširjenost piratstva pri namestitvah programske opreme ostaja v Sloveniji in svetu velik problem.

Krawczyk idr. (2014) navajajo številne študije, iz katerih izhaja, da je razširjenost piratske programske opreme najpogostejša med študenti, pri čemer kot vzrok navajajo različne dejavnike: ekonomske, socialne, kulturne, moralne, etične in zakonske. Tako tudi Butt, Butt in Fraser (2007) navajajo, da študentje $v$ razvijajočih se državah zaradi hitrejšega tehnološkega napredka potrebujejo dostop do cenejše programske opreme, ker želijo ostati na enaki ravni programske opremljenosti kot študentje zahodnih držav. Ob tem pa študija ugotavlja, da vlade razvijajočih se držav dopuščajo takšno ravnanje in ne uvajajo oziroma ne izvajajo zaščitnih zakonov avtorskih pravic, čeprav se zavedajo razširjenosti piratstva v lastnih državah (Butt, Butt in Fraser 2007).

Raghu, Machado in Shina (2014) ugotavljajo, da bi širša uporaba odprtokodne programske opreme in druge brezplačne programske opreme zmanjšala nagnjenost k "piratiziranju«. Znižanje naklonjenosti do nezakonitega nameščanja komercialne programske opreme (piratstva) bi vplivalo na nižje stroške zaščite komercialne programske opreme in $s$ tem na stroške izdelane komercialne programske opreme. Znižanje stroškov izdelave programske opreme bi vplivalo na nižje prodajne cene komercialne programske opreme, kar bi pripeljalo do višjega povpraševanja po tovrstni programski opremi.

Prav zaradi ugotovitev zgoraj navedenih študij glede bistvenih razlik med stopnjo uporabe piratske programske opreme $\mathrm{v}$ razvitih in razvijajočih se državah (B S A 2014) smo v empiričnem delu raziskave opravili raziskavo o razširjenost piratstva med študenti v Sloveniji, Srbiji, na Poljskem in v Veliki Britaniji. Pri izbiri držav smo, poleg Slovenije, 
izbrali tradicionalno razvito državo, državo, ki izhaja iz skupne polpretekle zgodovine in še ni članica $\mathrm{EU}$, ter vzhodnoevropsko državo, ki je polnopravna članica E U. Zaradi ugotovitev glede vpliva dohodka na stopnjo uporabe piratske programske opreme (Stryszowski in Scorpecci 2009) smo preverili tudi višino B D P na prebivalca v omenjenih državah, ki je v izbranih državah različna. ${ }^{3}$

$\mathrm{Z}$ raziskavo smo preverili naslednje hipoteze:

H1 Študentje, ki imajo višjo stopnjo I K T-pismenosti, ${ }^{4}$ imajo na računalniku nameščeno večje število piratske programske opreme od tistih z nižjo stopnjo IK T-pismenosti.

H 2 Glavni vzrok za razširjenost piratske programske opreme je njena preprosta dostopnost prek omrežij za izmenjavo datotek (angl. peer-to-peer).

H3 Obstajajo statistično značilne razlike med stopnjo nameščenosti ${ }^{5}$ piratske programske opreme na računalniku študenta posamezne države in razvitostjo države.

$\mathrm{H} 4$ Strožja zakonodaja ${ }^{6}$ na področju piratstva programske opreme bi zmanjšala stopnjo uporabe piratske programske opreme.

${ }^{3}$ Po podatkih Svetovne banke (glej http://data.worldbank.org) izhaja, da je bil v letu 2014 B D P na prebivalca v Sloveniji 23.999,13 U S D, v Srbiji 6.152,87 U S D, na Poljskem 14.342,91 U S D in v Veliki Britaniji 46.331,98 U S D.

${ }^{4}$ Višjo stopnjo I K T-pismenosti imajo skladno z metodologijo Eurostat (glej http://ec. europa.eu/eurostat/web/products-datasets/-/isoc_sk_cskl_i) tisti uporabniki računalnika, ki imajo razvitejše veščine pri opravljanju splošnih in naprednih opravil v okolju operacijskega sistema ter bolje razvite veščine pri uporabi osnovnih matematičnih operacij pri uporabi programov za delo s preglednicami, uporabi programov za stiskanje podatkov, uporabi programov za pripravo predstavitev, uporabi programov za zaščito računalnika pred virusi, povezovanju več računalnikov v mrežo in upravljanju. tovrstne mreže ter pri programiranju z uporabo računalniškega programskega jezika.

${ }^{5}$ Stopnjo nameščenosti piratske programske opreme smo ugotavljali po posameznih sklopih programske opreme, pri čemer smo ugotavljali število nameščenih piratskih programov glede na najpogostejši nabor nameščenih programov, ki jih pri delu uporabljajo študentje (operacijski sistem, pisarniška orodja, programi za urejanje slik, videa, predvajalniki glasbe, snemalniki CD/DVD, programi za stiskanje - zip idr.).

${ }^{6}$ Pomeni hipotetično možnost, da bi zakonodajalec uzakonil nadzor nad posameznikom prek spletnega operaterja, ki bi ugotavljal prenose prek omrežij P 2 P in kaznoval posameznike, nadziral prenesene vsebine $\mathrm{z}$ interneta, višal denarnih kazni za posameznika, zaostroval elemente kaznivosti (v smislu, da se dozdajšnje blažje kršitve, ki so opredeljene kot prekršek, prekvalificirajo (določijo) kot kaznivo dejanje). 



\section{Piratstvo}

Avtor ali izdajatelj programske opreme določi pogoje njene uporabe; $v$ licenčnih pogojih avtorji ali izdajatelji uporabniku programske opreme dodelijo ali omejijo pravice do predelave, distribucije, reprodukcije, objave avtorskega dela ali preostalih pravic, ki so vezane na pridobitev ali uporabo programske opreme (World Intellectual Property Organization 2004, 90). Nedovoljeno reproduciranje, distribuiranje in dajanje programske opreme $v$ najem je brez upoštevanja licenčnih pogojev avtorja, skladno $z$ določili v 21. in 113. členu Z A S P, nezakonito. Tovrstna ravnanja opredeljujemo kot piratstvo programske opreme. Takšno opredelitev potrjujejo tudi številni avtorji in organizacije, med katerimi so Moores in Dhilon (2000), Lau (2003), Nema (2014) in B S A (2014).

Osebo, ki izvede nedovoljeno kopiranje, distribuiranje ali dajanje $\mathrm{v}$ najem avtorsko zaščitene programske opreme, če ji licenca tega ne dovoljuje, imenujemo pirat.

\subsection{Splošno o piratstvu}

Osebni računalniki so se razširili dejansko v vsak dom v razvitem svetu; $s$ tem se je tudi povpraševanje po uporabniški programski opremi povečalo. Hkrati z zakonito ponudbo pa so se pojavili tudi ponudniki piratske programske opreme. Večina elektronskih naprav v svetu deluje oziroma izvaja predvidene operacije na podlagi zapisane programske kode, ki je - zakonsko gledano - avtorsko zaščiteno delo (Z A S P). Nepooblaščeno kopiranje in distribucija avtorskih del, kamor spada tudi programska oprema, sta protizakonita v večini držav na svetu. Pri tem moramo na računalniško programsko opremo gledati s posebno pozornostjo, saj tehnologija omogoča preprosto izmenjavo, kopiranje in namestitev na osebne računalnike (Nema 2014).

Razvoj piratstva računalniške programske opreme je povezan $\mathrm{z}$ razvojem računalništva in $s$ hitro rastjo števila uporabnikov računalniške opreme v zadnjih desetletjih (Novos in Waldman 2013). Nema (2014) ugotavlja, da je piratstvo programske opreme nastalo, ko so proizvajalci 
strojne in programske opreme svoje izdelke začeli prodajati ločeno. Novos in Waldman (2013) dodatno poudarjata, da sta bila za to pomembna tudi razvoj računalniške strojne in programske opreme ter razvoj komunikacijske tehnologije, ki omogoča hiter prenos podatkov med posameznimi uporabniki. Prav zaradi tehnološkega napredka so se stroški nakupa računalnika in komunikacijske opreme med uporabniki neprestano zniževali. V razvitem svetu danes zaznavamo visoke stopnje dostopnosti uporabnikov do širokopasovnih internetnih omrežij, ${ }^{1} \mathrm{ki}$ omogočajo hitre prenose velikih količin podatkov. Skozi zgodovino piratstva programske opreme je prav ta razvoj pogojeval različne načine reproduciranja, distribucije in trženja piratske programske opreme, ki danes dosega dejansko ves razviti svet in svet v razvoju (Klumpp 2013).

Za najrazširjenejšo obliko piratstva velja internetno piratstvo programske opreme (Marshal 2006). To sega v zgodnja osemdeseta leta dvajsetega stoletja, ko so računalniški navdušenci (angl. computer ge$e k s)^{2}$ oblikovali svoje navidezne klube, imenovane B B S (Bulletin Board System), v katerih so si izmenjevali programsko opremo, ki so jo večinoma pridobili pri gospodarskih družbah, v katerih so bili zaposleni (Craig, Honick in Brunett 2005). Takratni pirati niso zasledovali profitnih motivov, ampak sta jih vodila predvsem radovednost in raziskovanje zmožnosti komercialne programske opreme; ob svojih dejanjih so zato razmišljali o tem, kako bi odtujeno programsko opremo nadgradili z vidika funkcionalnosti in uporabniške izkušnje (Craig, Honick in Brunett 2005). Internetno piratstvo se je do današnjih dni razvilo tako, da se programska oprema med uporabniki prenaša neposredno s strežnikov, do katerih dostopamo prek internetnih strani, ali s pomočjo namenske programske opreme, ki omogoča pretakanje programske opreme neposredno $\mathrm{z}$ računalnikov drugih uporabnikov tovrstnih omrežij $^{3}$ (Klumpp 2013).

\footnotetext{
${ }^{1}$ V letu 2014 je v Sloveniji $99 \%$ uporabnikov interneta do slednjega dostopalo prek širokopasovnih povezav, glej http://pxweb.stat.si/pxweb/Dialog/varval.asp?ma=2974001S \&ti=\&path=../Database/Ekonomsko/23_29_informacijska_druzba/10_IKT _gospodinjstva/o4_29740_dostop_internet/\&lang=2.

${ }^{2}$ Slengovski izraz computer geek se uporablja predvsem v povezavi z računalniškimi navdušenci $z$ visoko stopnjo inteligence in znanja na računalniškem področju, pri čemer jih družba obravnava kot nedružabne in introvertirane osebe.

${ }^{3}$ Pri tem mislimo predvsem na omrežja P2 P (angl. peer-to-peer), pri katerih uporabnik namenskega računalniškega programa pretaka želeno vsebino od preostalih uporabnikov, povezanih v omrežju P 2 P, ki delijo želeno vsebino.
} 
Dahlstrom idr. (2006) ugotavljajo, da je razširjenost računalniškega piratstva posledica načina shranjevanja podatkov v digitalni obliki, pri čemer so vsi digitalni zapisi v binarnem zapisu. Takšna oblika zapisa je popolnoma prenosljiva med računalniki, pri reproduciranju tovrstnih podatkov pa ostaja kakovost zapisa enaka. Prav zaradi teh dejstev se je digitalno piratstvo, med katero uvrščamo tudi piratstvo programske opreme, razvilo v velikem obsegu. Ključno vlogo pri razširjanju piratske programske opreme prevzeli naslednji dejavniki (Dahlstrom idr. 2006):

- razvoj nosilcev digitalnih podatkov;

- tehnološki napredek na področju stiskanja digitalnih zapisov;

- razvoj internetnega omrežja, vključno z večjimi zmogljivostmi prenosa podatkov.

Organizacija B S A (2014) ocenjuje, da je bilo v letu 2013 v svetu 1,7 milijarde delujočih osebnih računalnikov. Pri tem ocenjujejo, da je bila skupna vrednost nameščene piratske programske opreme 62,71 milijarde ameriških dolarjev, kar sicer znaša manj kot v letu 2011, vendar je glede na predhodna opazovana obdobja vrednost nameščene piratske programske opreme narasla. ${ }^{4}$

Piratstvo digitalnih vsebin povzroča visoke stroške proizvajalcem in avtorjem na področju programske opreme, glasbe, filmske industrije in videoiger, vendar se bomo v monografiji osredinjali predvsem na piratstvo programske opreme.

Uporaba piratske programske opreme škodi avtorjem, proizvajalcem, prodajalcem in uporabnikom programske opreme, pri čemer Lancaster $(2004,4)$ škodo, ki nastaja uporabnikom piratske programske opreme, opredeljuje kot:

- povečano tveganje za prejem in širjenje računalniških virusov;

- pomanjkanje tehnične podpore pri uporabi programa;

- pomanjkanje jamstva za delovanje programa;

- izvajanje nadgradenj piratske programske opreme, ki je nezakonito;

- možnost odškodninskih zahtevkov in kazensko odgovornost posameznika.

V nadaljevanju Lancaster $(2004,4)$ opredeljuje tudi dejstva, ki škodijo proizvajalcem in prodajalcem programske opreme; ta so:

\footnotetext{
${ }^{4}$ Leta 2007 je znašala 47,81 milijarde U SD, leta 2009 51,44 milijarde U SD, leta 2011 pa 63,46 milijarde U S D (в S A 2014).
} 
- nižji prihodki od prodaje zaradi manjše prodaje programske opreme;

- nižja vlaganja v raziskave in razvoj nove programske opreme zaradi nižjih prihodkov;

- višje cene komercialne programske opreme zaradi zagotavljanja ustreznih prihodkov za financiranje razvoja programske opreme in delovanje gospodarske družbe.

Marshal $(2006,63)$ ugotavlja, da škoda s piratstvom programske opreme nastaja tudi državi v obliki nepobranih davkov. V pravnem smislu pa škodo, ki nastaja avtorjem programske opreme, opredeljujemo kot kršenje materialne avtorske pravice (Ovčak Kos 2015, 36).

\subsection{Pravna ureditev avtorskih pravic}

Avtorske pravice ureja Z ASP. Avtorsko pravico zakon priznava za avtorska dela, ki jih ustvari fizična oseba (10. člen), pri čemer avtorjem pripada avtorska pravica na podlagi stvaritve dela (14. člen). Z A S P v 15. členu avtorsko pravico opredeli kot enovito pravico avtorja. To pomeni, da iz avtorske pravice izvirajo izključna premoženjska upravičenja, ki jih poimenujemo materialne avtorske pravice (21. do 33. člen), in izključna osebnostna upravičenja, ki jih poimenujemo moralne avtorske pravice (16. do 20. člen). Materialne avtorske pravice avtorju dodeljujejo pravice udeležbe od materialnih koristi, uporabe dela; moralne avtorske pravice avtorju dodeljujejo moralna upravičenja od uporabe dela.

Avtorske pravice so ena izmed kategorij intelektualne lastnine, ki jo Urad Republike Slovenije za intelektualno lastnino opredeli kot pravico, ki izhaja iz intelektualne dejavnosti osebe na industrijskem, znanstvenem, literarnem in umetniškem področju. ${ }^{5}$

Poleg avtorskih pravic Urad Republike Slovenije za intelektualno lastnino v področje intelektualne lastnine uvršča še: ${ }^{6}$

- industrijsko lastnino, ki obsega patente, modele, znamke, geografsko označbo, patent s skrajšanim trajanjem in dodatni varstveni certifikat;

- preostale pravice, ki se nanašajo na specifična tehnična področja, kot sta topografija polprevodniških vezij in varstvo novih rastlinskih sort.

\footnotetext{
${ }^{5}$ Glej http://www.uil-sipo.si/uil/urad/o-intelektualni-lastnini/glosar/\#I.

${ }^{6}$ Glej http://www.uil-sipo.si/uil/urad/o-intelektualni-lastnini/.
} 
Država je v okviru zaščite intelektualne lastnine uzakonila pravice za zaščito intelektualne aktivnosti oseb; avtorske pravice, ki obsegajo tudi pravice, izvirajoče iz avtorstva računalniških programov, so normativno regulirane v okviru avtorskega prava (Vuga 2015, 30). Glavni namen avtorskega prava je predvsem zaščita avtorjev in njihovih stvaritev, pri čemer jim pravo podeljuje lastniška upravičenja na njihovih delih (Bogataj Jančič 2008, 3). Največja težava na področju avtorskega prava je nedvomno razvoj digitalne tehnologije, ki s seboj prinaša stroškovno zanemarljivo reproduciranje avtorskih del v velikem obsegu in ohranitev visoke kakovosti reproduciranega dela (Bogataj Jančič 2008, 3). Razvoj tehnologije in internetnega prostora je ustvaril okolje, v katerem obstajajo najboljše možnosti za kopiranje digitalnih vsebin in slabe možnosti za pravno varstvo avtorskih pravic, pri čemer se postavlja vprašanje, ali avtorsko pravo s tehnološkim napredkom še izpolnjuje svojo normativno vlogo (Breznik Močnik idr. 2008). Med drugimi je namen avtorske stvaritve tudi razširjanje avtorskega dela, znanja in misli med ljudmi (Ovčak Kos 2015, 18). Pretirana zaščita avtorskih pravic lahko pripelje do ravno nasprotnega učinka, in sicer da avtorsko delo postane samo sebi namen ter onemogoča širjenje znanja. To pa nikakor ni namen avtorjev, saj bi taka restrikcija pripeljala do zastoja napredka družbe (Breznik Močnik idr. 2008, 16).

ZAS P v členih od 16 do 39 opredeljuje izključna osebnostna upravičenja, ki izvirajo iz avtorske pravice; ta so:

- moralne avtorske pravice (od 16. do 20. člena), ki predstavljajo varstvo avtorja $z$ vidika duhovnih in osebnih vezi na avtorsko delo; ${ }^{7}$

- materialne avtorske pravice (od 21. do 33. člena), ki predstavljajo varstvo avtorja $z$ vidika njegovih premoženjskih interesov, s tem da avtor dovoljuje ali prepoveduje uporabo svojega avtorskega dela ter pri tem udejanja zakonsko dovoljene pravice; ${ }^{8}$

- druge avtorske pravice (od 34. do 39. člena), ki avtorju zagotavljajo predvsem denarno nadomestilo za uporabo njegovih avtorskih del.

\footnotetext{
${ }^{7} \mathrm{Za}$ avtorstvo programske opreme se udejanjajo naslednje moralne avtorske pravice: pravica do prve objave (17. člen), pravica priznanja avtorstva (18. člen), pravica spoštovanja dela (19. člen) in pravica skesanja (20. člen).

${ }^{8} \mathrm{Za}$ avtorstvo programske opreme se najpogosteje udejanjajo naslednje materialne avtorske pravice: pravica reproduciranja (23. člen), ki določa shranjevanje in kopiranje računalniškega programa, pravica distribuiranja (24. člen), ki določa prenose lastninske pravice na avtorskem delu, in pravica dajanja v najem (25. člen).
} 
Mednarodno avtorsko pravo temelji na Bernski konvenciji za varstvo književnih in umetniških del, ki je bila sprejeta leta 1886 (Bogataj Jančič 2008). Na Bernski konvenciji temeljijo tudi vse pomembnejše mednarodne avtorske pogodbe. Tako je na njeni podlagi leta 1996 nastala Pogodba svetovne organizacije za intelektualno lastnino o avtorski pravici (W I P O Copyright Treaty). Ta obsega tudi zaščito pravic avtorjev računalniških programov (World Intellectual Property Organization 1996). Podpisnice Bernske konvencije in Pogodbe svetovne organizacije za intelektualno lastnino o avtorski pravici so tudi Slovenija, Srbija, Poljska in Velika Britanija. ${ }^{9}$

Harmonizacijo zakonodaje, ki izvira iz Direktive sveta z dne 24. 5 . 1991 o pravnem varstvu računalniških programov 91/250/E G S, ${ }^{10}$, ki prav tako upošteva določila Bernske konvencije, so izvedle tudi preostale države E U. Direktiva 91/250/E G S je bila prva, ki je bila sprejeta v okviru harmonizacije avtorskega prava Evropske skupnosti (Ovčak Kos 2015, 68). Njen namen je bil uveljavitev pravnega varstva računalniških programov v državah E U, v katerih tako pravno varstvo ni obstajalo. Z Direktivo 91/250/E G S se je pravno varstvo med članicami izenačilo. Direktiva opredeljuje, da je razvoj računalniških programov temeljnega pomena za razvoj industrijske dejavnosti E U (Ovčak Kos 2015, 68). V 2. členu določa tudi pojem avtorstva ${ }^{11}$ in v 4. členu opredeljuje dejanja, za katera je treba pridobiti dovoljenja imetnika avtorske pravice. ${ }^{12}$ Nadalje v 1. členu opredeljuje predmet varstva avtorske pravice na računalniškem programu, pri čemer to obsega računalniški program in pripravljalno gradivo za njegovo izdelavo. Direktiva določa tudi, da morajo vse države članice v okviru harmonizacije nacionalne zakonodaje predvideti ukrepe (sankcije) za osebe, ki:

- dajejo v promet nedovoljene kopije računalniškega programa;

- imajo v posesti kopijo računalniškega programa in jo uporabljajo $\mathrm{v}$ komercialne namene;

${ }^{9}$ Glej http://www.wipo.int/treaties/en/ShowResults.jsp?lang=en\&treaty_id=15 in http: //www.wipo.int/treaties/en/ShowResults.jsp?lang=en\&treaty_id=16.

${ }^{10}$ Uradni list Evropske unije, št. L 122/42.

${ }^{11}$ „Avtor računalniškega programa je fizična oseba ali skupina fizičnih oseb, ki je ustvarila program ali, če zakonodaja države članice to dovoljuje, pravna oseba, ki po tej zakonodaji velja za imetnika pravice« (Direktiva 91/250/E G S).

${ }^{12}$ Dovoljenja, ki jih podeljuje izključno imetnik pravice, so: reproduciranje delov ali celotnega računalniškega programa, prevod, priredba ali predelava računalniškega programa in vsaka oblika distribuiranja ali dajanja $\mathrm{v}$ najem računalniškega programa ali njegovih kopij (Direktiva 91/250/E G S). 
- dajejo v promet ali imajo v posesti kakršna koli sredstva, namenjena za neupravičeno odstranitev ali izognitev tehničnim ukrepom, ki so namenjeni zaščiti računalniškega programa.

V 7. členu Direktive 91/250/EGS je določeno, da države članice v okviru lastne zakonodaje predvidijo zaseg nedovoljenih kopij računalniških programov in zaseg sredstev, ki so namenjena neupravičeni odstranitvi ali izognitvi tehničnim ukrepom, katerih namen je zaščita računalniškega programa. Slovenija, Velika Britanija in Poljska so v okviru harmonizacije zakonodaje s področja zaščite avtorskih pravic na računalniških programih prenesle evropske pravne norme v lastno zakonodajo. Srbija v predpristopnih pogajanjih z Evropsko komisijo usklajuje 33 področij, pri čemer je sedmo področje namenjeno usklajevanju zakonodaje na področju intelektualne lastnine (European Commision 2014). $\mathrm{Na}$ področju avtorskih in sorodnih pravic je $\mathrm{v}$ okviru predpristopnih pogajanj Srbija v večji meri uskladila zakonodajo s področja avtorskega prava in zakonodajo s področja sankcioniranja kršitev avtorskih pravic. Evropska komisija državi očita, da predpisane avtorske zakonodaje v praksi ne izvaja v zadostni meri. Prav zaradi tega mora Srbija za izpolnitev predpristopnih pogojev za vstop v EU dosledneje izvrševati zakonodajo s področja zaščite avtorskih del, tudi na področju piratstva programske opreme (European Commision 2014).

V vseh preučevanih državah so uzakonjene tudi pravne norme, ki določajo kaznivost kršenja avtorskih pravic in obsegajo tudi kršitve avtorskega prava na področju računalniških programov ter so $\mathrm{v}$ posamezni državi regulirane $\mathrm{v}$ zakonu, ki ureja varstvo avtorskih pravic, ali $\mathrm{v}$ specialnem zakonu, ki ureja kazensko pravo.

V nadaljevanju prikazujemo pregled zakonske ureditve avtorskih pravic v Sloveniji, Srbiji, na Poljskem in v Veliki Britaniji.

\section{Slovenija}

Republika Slovenija je podpisnica Bernske konvencije, ki je stopila v veljavo leta 1991. Prav tako je Slovenija tudi podpisnica Pogodbe svetovne organizacije za intelektualno lastnino o avtorski pravici. Pogodbo je podpisala 12. 12. 1997, ratificirala 19. 11. 1999, v veljavo pa je stopila 6. 3. 2002. ${ }^{13}$

Avtorska pravica, ki je posledica avtorskega ustvarjanja, je v slovenskem pravu tako pomembna, da je varovana $\mathrm{z}$ ustavo; avtorju je pode-

${ }^{13}$ Glej http://www.wipo.int/treaties/en/ShowResults.jsp?lang=en\&treaty_id=15 in http: //www.wipo.int/treaties/en/ShowResults.jsp?lang=en\&treaty_id=16. 
ljena na podlagi stvaritve dela, iz česar izhaja, da avtorju njegovega dela ne moremo odvzeti in ima absolutno pravico do premoženjskega izkoriščanja svojega dela (Ovčak Kos 2015, 34). Ustava Republike Slovenije ${ }^{14} \mathrm{~V}$ svojem 6o. členu zagotavlja "varstvo avtorskih in drugih pravic, ki izvirajo iz umetniške, znanstvene, raziskovalne in izumiteljske dejavnosti«. Zakon, ki ureja avtorske pravice in določa obseg avtorskih pravic na področju programske opreme, je Z A S P, ki v 5. členu kot avtorsko varovano delo opredeljuje tudi računalniške programe.

Pomembnejše določbe $\mathrm{Z}$ AS P glede avtorskih pravic na računalniških programih so zapisane v 36. členu ZASP, ki določa, da je javno posojanje izvirnikov računalniških programov izključna avtorjeva pravica. Povezano s tem je nedvoumno tudi določilo v 50. členu, ki določa, da tudi zasebno in drugo lastno reproduciranje računalniških programov ni dovoljeno.

ZASP še posebej natančno opredeljuje avtorske pravice, ki izhajajo iz avtorstva računalniških programov v drugem oddelku četrtega poglavja zakona, in sicer od 111. do 117. člena. z A S P določa, da računalniški programi uživajo varstvo tega zakona samo, če gre za lastno intelektualno stvaritev avtorja računalniškega programa, pri čemer računalniški program v 111. členu opredeli kot "računalniški program v vsaki izrazni obliki, vključno s pripravljalnim gradivom za njegovo izdelavo«.

Za preprečevanje škode, ki nastane kot posledica piratstva, so proizvajalci programske opreme in drugih digitalnih vsebin začeli uporabljati t. i. tehnične ukrepe za zaščito avtorskih del, saj pravna zaščita ni zadostovala (Breznik Močnik idr. 2008). Tehnični ukrepi obsegajo zaščito pred kopiranjem in zaščitne mehanizme za preprečevanje nepooblaščene uporabe programov (Bogataj Jančič 2008). Dejstvo je, da v večini primerov vdiralci ${ }^{15}$ uspejo v zelo kratkem času odstraniti tehnične zaščite, ki varujejo računalniške programe pred uporabo v nasprotju $\mathrm{z}$ licenčnimi pogoji (Craig, Honick in Brunett 2005). Izogibanje tehničnim ukrepom, ki so namenjeni zaščiti avtorskih pravic na avtorskih delih, je v 166.a čl. Z A S P opredeljeno kot nezakonito.

Kazenske določbe Z AS P so opredeljene $\mathrm{v}$ devetem poglavju zakona, in sicer v členih od 184 do 186. Z A S P v 184. in 185. členu opredeljuje denarno globo za storjeni prekršek, ki ga izvrši pravna oseba ali samo-

${ }^{14}$ Uradni list Republike Slovenije, št. 33/91-I, 42/97, 66/oo, 24/o3, 69/o4, 68/o6, 47/13.

${ }^{15}$ Vdiralec ali kreker (angl. cracker) je oseba, ki zlomi oziroma razbije zaščito programske opreme z namenom nepooblaščene uporabe in/ali distribucije (ISlovar 2016). 
stojni podjetnik, vključno z odgovornimi osebami pravnega subjekta. Dejanja, ki predstavljajo prekršek po 184. členu, so opredeljena kot nedovoljena reprodukcija, distribucija, dajanje $v$ najem in izognitev tehničnim sredstvom za zaščito avtorskega dela, 185. člen pa opredeljuje prekrške v povezavi s pošiljanjem podatkov kolektivnim organizacijam za izračun nadomestila avtorjem. Po ZASP je skladno s 186. členom pristojnost za izvedbo nadzora in sankcioniranje kršilcev prenesena na Tržni inšpektorat Republike Slovenije. Isti člen Tržnemu inšpektoratu Republike Slovenije podeljuje tudi pristojnost za zaseg predmetov, ki so bili uporabljeni ali so bili namenjeni za storitev prekrška ali so s prekrškom nastali.

Po slovenski zakonodaji je kaznivo dejanje tisto protipravno dejanje, ki je z zakonom zaradi varovanja pravnih vrednot določeno za kaznivo; kazniva dejanja so za družbo najnevarnejša dejanja in posegajo $\mathrm{v}$ temeljne človekove pravice ter premoženje. Prekršek prav tako pomeni protipravno dejanje, vendar je v nasprotju s kaznivim dejanjem intenzivnost posega v pravno zavarovane dobrine bistveno milejša (Pavčnik 2015, 112). Vsa kazniva dejanja v Republiki Sloveniji so urejena v Kazenskem zakoniku (KZ-1). ${ }^{16}$

Kazniva dejanja na področju avtorskega prava so urejena v 16. poglavju Kazenskega zakonika, ki določa kazniva dejanja zoper človekove pravice in svoboščine v členih od 147 do 149 (K Z-1).

Kaznivost dejanj v povezavi s kršenjem moralnih avtorskih pravic določa 147. člen KZ-1, ki za kaznivo dejanje opredeljuje objavo avtorskega dela s svojim imenom ali z imenom koga drugega, prikaz, izvedbo ali prenos tujega avtorskega dela. Kazniva je tudi skazitev, okrnitev ali drug neupravičen poseg v tuje avtorsko delo.

Kaznivost dejanj v povezavi s kršenjem materialnih avtorskih pravic določa 148. člen KZ-1, ki kot kaznivo dejanje opredeljuje neupravičeno uporabo enega ali več avtorskih del ali njihovih primerkov, katerih skupna tržna cena predstavlja večjo premoženjsko vrednost. ${ }^{17}$

Bistvena sprememba kazenske zakonodaje ob kršenju avtorskih pravic se je zgodila v letu 2011 z dopolnitvijo Kazenskega zakonika (K Z-1). Prvi odstavek 148. člena KZ-1 je pred navedeno spremembo zakona določal: »Kdor z namenom prodaje neupravičeno uporabi eno ali več avtor-

${ }^{16}$ Uradni list Republike Slovenije, št. 55/o8, 66/o8, 39/o9, 91/11, 54/15.

${ }^{17}$ Pojem večje premoženjske vrednosti je opredeljen v 2. tč. 9. odst. 99. člena KZ-1, in sicer predstavlja vrednost, ki je večja od 5.000,00 E U R. 
skih del«, pri čemer je bila s spremembo zakona črtana besedna zveza "Z namenom prodaje«. ${ }^{18}$

Četrti odstavek 148. člena K Z-1 določa tudi odvzem nezakonitih primerkov avtorskega dela in naprav za njihovo reproduciranje.

Za opredelitev kazenske odgovornosti posameznika in izvršitev kaznivih dejanj s področja kršenja materialnih avtorskih pravic je treba upoštevati tudi pogoje 5 . odstavka 148 . člena $\mathrm{KZ}-1,{ }^{19}$ ki določa način pridobitve koristi iz naslova zlorabe avtorsko zaščitenega dela. Pri ugotavljanju večje vrednosti na področju kršenja avtorskih pravic 5. odstavek 148. člena določa, da se upošteva korist, ki jo kršilec pridobi z neupravičeno uporabo materialnih avtorskih pravic, neupravičenim reproduciranjem, razširjanjem, dajanjem na voljo javnosti ali dajanjem v najem avtorski sorodnih pravic s pridobitnim namenom.

K Z-1 za kaznivo dejanje ne opredeljuje posredovanja internetnih ali kakršnih koli drugih povezav, ki omogočijo prenos (tudi nezakonite) programske opreme, na lastni računalnik (Zgaga 2011). Prav zato se ponudniki povezav do piratskih vsebin venomer opredeljujejo kot subjekti, ki s piratsko programsko opremo nimajo neposredne povezave. Tovrstna programska oprema oz. njene namestitvene datoteke se dejansko nahajajo na drugih strežnikih ali računalnikih posameznih uporabnikov. Te vsebine lahko prenesemo s pomočjo omrežij P 2 P, ki so namenjena prav za hiter prenos digitalnih vsebin (Zgaga 2011).

Kaznivost dejanj v povezavi s kršenjem avtorski sorodnih pravic določa 149. člen KZ-1, ki za kaznivo dejanje opredeljuje reproduciranje, razširjanje, dajanje $\mathrm{v}$ najem ali dajanje na voljo javnosti eno ali več izvedb videogramov, fonogramov, RT V-oddaj ali podatkovnih baz, katerih vrednost predstavlja večjo premoženjsko korist.

Sankcije, ki so v KZ-1 predvidene za kršitev moralnih avtorskih pravic (147. člen), so predvidene $v$ obliki denarne in zaporne kazni do enega leta. Za kršitev materialnih avtorskih pravic (148. člen) so predvidene zaporne kazni do 8 let. Enake zaporne kazni so predvidene tudi za krši-

${ }^{18} \mathrm{~K}$ Z-1 s spremembo 148. člena inkriminira vse kršitve materialnih avtorskih pravic nad zakonsko določeno vrednostno mejo, pri čemer se je hotel zakonodajalec prilagoditi trendom zlorabe avtorskih del, pri čemer prodaja zaradi razvoja I K T in hitrih internetnih povezav ne predstavlja pretežnega dela kršitev avtorske zakonodaje (Zgaga 2011).

19 »Pri ugotavljanju premoženjske vrednosti po določbah tega člena in 149. člena tega zakonika se upošteva korist iz neupravičene uporabe materialnih avtorskih pravic oziroma neupravičenega reproduciranja, dajanja na voljo javnosti, razširjanja ali dajanja $v$ najem avtorski sorodnih pravic v pridobitne namene« (K Z-1). 
tev avtorski sorodnih pravic (149. člen). Iz navedenega lahko sklepamo, da se je kazenskopravna zakonodaja na področju kršenja avtorskih pravic v Republiki Sloveniji v zadnjem obdobju sicer nekoliko zaostrila, vendar ne v zadostni meri, da bi kot taka večino uporabnikov piratske programske opreme odvračala od kršitve avtorskih pravic. Kot problematično vidimo tudi pomanjkanje pravnih norm, ki bi določale kaznivost posredovanja povezav do piratske programske opreme. Treba je poudariti, da bi pristojni organi takšna določila težko izvrševali, saj je krajevna pristojnost zakona vezana na območje Republike Slovenije, dejansko pa se ponudniki spletnih povezav do nezakonitih datotek nahajajo na strežnikih po vsem svetu.

\section{Poljska}

Poljska je podpisnica Bernske konvencije od 28. 1. 1920. Poleg tega je tudi podpisnica Pogodbe svetovne organizacije za intelektualno lastnino o avtorski pravici, in sicer je k pogodbi pristopila 23. 12. 2003, v veljavo pa je stopila 23. 3. 2004. ${ }^{20}$

Država je - tako kot preostale članice E U - harmonizirala zakonodajo na področju regulacije avtorskih pravic $z$ evropsko zakonodajo. Zakon, ki normativno ureja področje avtorskih pravic na Poljskem, je Zakon o avtorski in drugih pravicah in je bil sprejet leta 1994 (Slusarek 2003).

Poljski Zakon o avtorski in sorodnih pravicah (P-ZASP) ${ }^{21}$ podobno kot slovenski ZASP v 1. členu računalniške programe opredeljuje kot avtorsko zaščiteno delo. P-ZASP vsebuje posebne določbe o zaščiti računalniških programov, ki se nahajajo $\mathrm{v}$ sedmem poglavju zakona (od 74. do 77. člena) in dodeljujejo ekonomska upravičenja avtorju računalniškega programa; ta so:

- pravica do reproduciranja računalniškega programa;

- pravica do distribuiranja računalniškega programa, vključno s posojanjem in $\mathrm{z}$ dajanjem $\mathrm{v}$ najem;

- avtorska pravica ob prevodu, prirejanju programa ali katere koli druge predelave programa pripada osebi, ki je takšno spremembo naredila.

P-ZAS P v 75. členu določa izjeme, pri katerih je dovoljeno poseči v

${ }^{20}$ Glej http://www.wipo.int/treaties/en/ShowResults.jsp?lang=en\&treaty_id=15 in http: //www.wipo.int/treaties/en/ShowResults.jsp?lang=en\&treaty_id=16.

${ }^{21}$ Glej http://www.wipo.int/wipolex/en/details.jsp?id=350o. 
izključne avtorjeve pravice na računalniških programih, ki po P-ZAS P obsegajo:

- izdelavo varnostne kopije, če je ta potrebna za uporabo programa, ki ne sme biti uporabljena sočasno $\mathrm{z}$ osnovnim programom;

- analizo, študije in eksperimentiranja $\mathrm{z}$ računalniškim programom z namenom ugotovitve njegovega delovanja;

- reprodukcijo izvorne kode, ki je potrebna za pridobivanje informacij za interoperabilnost delovanja različnih programov; pridobljenih informacij oseba ne sme razkriti tretjim osebam, nastajajoči program pa ne sme biti v nobenem smislu podoben tistemu, od katerega izvorno kodo je pridobil, saj bi to pomenilo kršenje avtorskih pravic.

Kazensko odgovornost na področju avtorskih pravic normativno ureja P-ZASP, ${ }^{22}$ ki določa pogoje kaznivosti kršenja avtorskih in sorodnih pravic ter sankcije ob obsodbi za tovrstna kazniva dejanja. Inkriminirana so vsa dejanja v povezavi z zlorabo avtorskih del, nepooblaščenim reproduciranjem in s kopiranjem avtorskih del. Za storilce teh dejanj je v 115. členu predvidena zaporna kazen od 6 mesecev do 3 let. Če se predhodno navedena dejanja izvršujejo z namenom pridobitve premoženjske koristi ali v organizirani združbi (118. člen), so z zakonom zagrožene do 5-letne zaporne kazni. Poleg omenjenega kazensko odgovornost ureja tudi poljski kazenski zakonik, in sicer ta v poglavju kaznivih dejanj zoper premoženje določa, da se, če katera koli oseba neupravičeno pridobi programsko opremo $\mathrm{z}$ namenom pridobitve premoženjske koristi, ta oseba kaznuje z zaporno kaznijo od 3 mesecev do 5 let (Rychlicki 2011).

Organizacija I I PA (International Intellectual Property Alliance) ${ }^{23}$ je v svojem zadnjem letnem poročilu za Poljsko izdala opozorilo, da se distribucija digitalnih piratskih proizvodov z ulic seli predvsem na internet (International Intellectual Property Alliance 2011). Poročilo poudarja, da je problematično območje poljsko-nemške meje, na katerem se izvaja prodaja elektronskih nosilcev podatkov (CD, DVD) s primarnim ciljnim trgom v Nemčiji in nadalje v celotni E U. Kljub normativno urejeni zakonski ureditvi na področju zaščite avtorskih pravic na Poljskem je pri-

\footnotetext{
22 14. poglavje, Kazenska odgovornost, členi od 115 do 123.

${ }^{23}$ Organizacija IIPA zastopa ameriške gospodarske družbe, ki v okviru opravljanja njihove dejavnosti izdajajo in distribuirajo avtorsko zaščitene vsebine.
} 
sotnost piratske programske opreme med uporabniki še vedno med višjimi v EU. ${ }^{24}$

\section{Velika Britanija}

Velika Britanija je podpisnica Bernske konvencije, in sicer je konvencijo podpisala 9. 9. 1886, ratificirala 5. 9. 1887, v veljavo pa je stopila 5. 12. 1887. Hkrati je tudi podpisnica Pogodbe svetovne organizacije za intelektualno lastnino o avtorski pravici, in sicer je pogodbo podpisala 13. 2. 1997, jo ratificirala 14. 12. 1999, v veljavo pa je stopila 6. 2. 2002. ${ }^{25}$

Velika Britanija je prva, ki je normativno uredila zaščito avtorskih pravic s sprejetjem zakona o avtorskih pravicah, in sicer leta $1710 .^{26}$ Zakon iz leta 1710 in nadaljnja sodna praksa sta predstavljala pravno osnovo za sprejetje vrste naslednjih zakonov s področja zaščite intelektualne lastnine in avtorskih pravic, pri čemer velja omeniti zadnji veljavni zakon, in sicer Copyright, Designs and Patents Act iz leta 1988. ${ }^{27}$

Pojmovanje avtorske pravice $v$ Veliki Britaniji se povsem razlikuje od kontinentalnega pojmovanja. Britansko avtorsko pravo avtorsko pravico obravnava kot čisto premoženjsko pravico in jo opredeljuje $z$ izključnimi materialnimi upravičenji, kar pomeni, da avtorsko delo razume kot tržno dobrino. Razlika s kontinentalnim pravom je izpostavljena že v osnovnem pojmovanju, saj ne enači avtorstva (angl. authorship) $\mathrm{z}$ avtorsko pravico (angl. copyright) (Ovčak Kos 2015).

$\mathrm{Za}$ zaščito avtorskih pravic na področju računalniških programov je Velika Britanija leta 1992 dopolnila Copyright, Designs and Patents Act iz leta 1988, in sicer $z$ uredbo za zaščito avtorskih pravic za računalniške programe (The Copyright Computer Programs Regulations - C C PR), ${ }^{28}$

${ }^{24}$ Povprečna stopnja nameščenosti piratske programske opreme na Poljskem znaša $51 \%$ in V EU 31\% (BSA 2014, 9). Povprečno stopnjo nameščenosti piratske programske opreme BSA $(2014,12)$ izračuna kot razmerje med nameščeno piratsko programsko opremo in celotno programsko opremo, nameščeno na računalniku.

${ }^{25}$ Glej http://www.wipo.int/treaties/en/ShowResults.jsp?lang=en\&treaty_id=15 in http: //www.wipo.int/treaties/en/ShowResults.jsp?lang=en\&treaty_id=16.

${ }^{26}$ Britanski zakon o avtorskih pravicah, imenovan tudi The Statute of Anne, je stopil v veljavo 10. 4. 1710 in je avtorju dela dodelil pravico tiskanja ter ponatisa njegovega dela; naslednji državi, ki sta sprejeli podobne zakone, sta bili Francija leta 1793 ter Nemčija leta 1794 (Khong 2006).

${ }^{27}$ Glej http://www.legislation.gov.uk/ukpga/1988/48/contents.

${ }^{28}$ Glej http://www.legislation.gov.uk/uksi/1992/3233/made; regulativa št. 3233 je stopila V veljavo 1. 1. 1993 kot posledica implementacije Evropske direktive, št. 91/250/E G S, in $\mathrm{v}$ celoti ureja zaščito avtorskih pravic za področje računalniških programov. 
ki določa obseg avtorskih pravic in ravnanja, ki pomenijo kršitev teh pravic na področju piratstva programske opreme. C CPR - podobno kot zakonodaja drugih obravnavanih držav - uveljavlja zaščito računalniških programov kot avtorskega dela na področju literarnega dela in jim podeljuje vse pravice, ki jim na podlagi stvaritve tega dela pripadajo.

Zakonodaja Velike Britanije ne pozna kazenskega zakonika kot samostojnega zakona, so pa kazenske določbe vključene v Copyright, Designs and Patents Act (CD PA) iz leta 1988. ${ }^{29}$ Tako je za kršenje avtorskih pravic na področju programske opreme predvidena civilnopravna in/ali kazenskopravna odgovornost, če so za to izpolnjeni zakonski pogoji kršenja avtorskih pravic (IP O 2014). Leta 2003 je bila sprejeta dopolnitev CD PA iz leta 1988, in sicer $z$ uredbo o zaščiti avtorskih in sorodnih pravic (The Copyright and Related Rights Regulations $2003-\mathrm{CRRR}),{ }^{30} \mathrm{ki}$ opredeljuje kazniva ravnanja v povezavi z zlorabo avtorskih pravic tudi na področju programske opreme.

Kazniva dejanja v povezavi s kršenjem avtorskih pravic na področju računalniških programov so opredeljena kot nezakonita ravnanja $\mathrm{v}$ povezavi s 1. odstavkom 107. člena CDPA, in sicer se nanašajo na kršitve avtorskih pravic in nepooblaščeno kopiranje optičnih medijev, računalniških programov in iger, pri čemer so zagrožene neomejene denarne kazni in do 10 let zaporne kazni. CR R R podrobneje določa tudi kazniva ravnanja posameznika, ki zaobide tehnične rešitve, namenjene zaščiti pred kopiranjem programov, pri čemer je kazenski pregon mogoč v primerih, ko oseba doda tehnično rešitev programu, ki omogoča njegovo kopiranje, in se zaveda, da takšna rešitev omogoča kršitev avtorskih pravic na programski opremi. ${ }^{31}$ Za pregon kaznivih dejanj v povezavi $s$ kršenjem avtorskih pravic na področju računalnikih programov je v Veliki Britaniji pristojno državno tožilstvo, v nekaterih primerih pa tudi organizacije, ki zastopajo pravice lastnikov avtorskih pravic.

\section{Srbija}

Srbija je podpisnica Bernske konvencije, in sicer od 27. 4. 1992, pri čemer je bila 19. 9. $2006 \mathrm{z}$ izjavo o nadaljnji uporabi potrjena njena nadaljnja

\footnotetext{
${ }^{29}$ Glej http://www.cps.gov.uk/legal/h_to_k/intellectual_property_crime/\#content.

${ }^{30}$ Glej http://www.legislation.gov.uk/uksi/2003/2498/pdfs/uksi_20032498_en.pdf.

${ }^{31}$ Določbe, ki podrobneje določajo kazniva ravnanja v povezavi z onemogočanjem tehničnih rešitev pred kopiranjem programske opreme, so določene v členih 296, 296 ZA, 296 $\mathrm{ZB}, 296 \mathrm{ZE}$ in $296 \mathrm{ZF}$.
} 
uporaba. Hkrati je tudi podpisnica Pogodbe svetovne organizacije za intelektualno lastnino o avtorski pravici, in sicer je $\mathrm{k}$ pogodbi pristopila 13. 3. 2003, v veljavo pa je stopila 13. 6. 2003. ${ }^{32}$

V Srbiji je stopnja piratstva programske opreme zelo visoka. ${ }^{33} \mathrm{G}$. Lalović $(2009,38)$ ugotavlja, da so visoke stopnje piratstva posledica pretekle srbske politike v času Miloševića, ${ }^{34}$ ki je kot akt protizahodnega protesta spodbujala kršitev avtorskih pravic tujih avtorjev. Še leta 2005 je bilo mogoče kupiti zgoščenke s piratskimi vsebinami, tudi z računalniškimi programi v trafikah in na srbskih ulicah na ozemlju celotne Republike Srbije.

Republika Srbija je leta 2011 začela izvajati strategijo razvoja o zaščiti intelektualne lastnine $z$ namenom zaščite avtorskih in drugih pravic, ki izhajajo iz stvaritev avtorskih del (US Department of State 2015). S tem namenom je ustanovila urad, ki koordinira in povezuje delo policije, davčne inšpekcije, carine in drugih državnih inšpekcijskih služb za pregon kršenja avtorskih ter drugih pravic. Kljub sorazmerno strogi normativni opredelitvi kršenja avtorskih in drugih pravic v Srbiji pa ostaja prisotna zelo visoka stopnja ponudbe piratske programske opreme, saj pristojne službe ne izvršujejo v zadostni meri ukrepov, ki jih nalaga zakonodaja za zmanjševanje piratstva. Temu dejstvu pritrjuje tudi Evropska komisija (European Commision 2014, 27), ki opozarja na pomanjkljivo sodelovanje deležnikov v procesu učinkovitejšega pregona kršilcev na področju kršenja pravic intelektualne lastnine.

Danes ima Republika Srbija normativno ureditev na področju zaščite avtorskih pravic urejeno $\mathrm{v}$ zakonu o avtorskih in sorodnih pravicah ( $\mathrm{Za}$ kon o autorskim i surodnim pravima - ZAISP) ${ }^{35}$ ki je bil sprejet leta 2009. ZAISP, podobno kot vsi drugi preučevani zakoni s področja zaščite avtorskih pravic, kot avtorsko zaščiteno delo opredeljuje tudi računalniške programe. Avtorje računalniških programov obravnava enako kot avtorje pisanih del (knjig, brošur, člankov, prevodov, ipd.). ZAIS P je usklajen $\mathrm{z}$ evropsko zakonodajo in direktivami Svetovne trgovinske organizacije (Milić 2011).

${ }^{32}$ Glej http://www.wipo.int/treaties/en/ShowResults.jsp?lang=en\&treaty_id=15 in http: //www.wipo.int/treaties/en/ShowResults.jsp?lang=en\&treaty_id=16.

${ }^{33}$ Povprečna stopnja nameščenosti piratske programske opreme v Srbiji znaša 67\% (B S A 2014).

${ }^{34}$ Slobodan Milošević je bil predsednik Srbije in Zvezne Republike Jugoslavije v obdobju od 1989 do 2000.

${ }^{35}$ Službeni glasnik Republike Srbije, št. 104/2009, 99/2011 in 119/2012. 
ZAIS P določa materialne, moralne in druge pravice avtorjev, pri čemer 47. člen kot posebnost dovoljuje izdelavo varnostne kopije programa na fizičnem nosilcu. Z A IS P v 215. členu kot protizakonito opredeljuje tudi vsako izogibanje tehničnim ukrepom, ki so namenjeni zaščiti avtorskega dela, in vsakršno dejanje, ki uporabniku omogoča pridobitev takih tehničnih sredstev. V kazenskih določbah (členi od 215 do 217) zakon predvideva, da so pravne osebe za kršenje zakonodaje sankcionirane $z$ denarno kaznijo, pri čemer se nezakonite primerke odvzame in uniči.

Srbska zakonodaja ob kršenju avtorskih pravic pri izpolnitvi zakonskih pogojev predvideva civilnopravno, kazenskopravno in upravnopravno odgovornost (Simić 2015). Civilnopravno zaščito avtorskih pravic določa vrsta zakonov s področja zaščite intelektualne lastnine, ${ }^{36}$ medtem ko je kazenskopravna odgovornost opredeljena v kazenskem zakoniku (Krivični zakonik), upravnopravno zaščito avtorskih pravic pa predstavljata predvsem ustanovitev in dodelitev pristojnosti ter pooblastil inšpekcijskim službam in carinskim organom za izvajanje upravnih sporov pred pristojnimi sodišči (Simić 2015).

Kazenski zakonik Republike Srbije (Krivični zakonik Republike Srbije - KZRS), ${ }^{37}$ opredeljuje kazniva dejanja v povezavi s kršenjem avtorskih in drugih pravic na področju računalniških programov v 199. in 20o. členu, ki opredeljujeta, da so nepooblaščena objava, snemanje, razmnoževanje ali posest nezakonitih izvodov z namenom dajanja v promet kaznivi. Kaznivo je tudi posredovanje ali reklamiranje tehničnih sredstev, s katerimi je mogoče zaobiti tehnične ovire za zaščito računalniških programov. KZ RS predvideva sankcije v obliki denarne kazni in zaporne kazni v trajanju od 6 mesecev do 5 let.

\subsection{Vrste piratstva}

Piratsko programsko opremo je mogoče pridobiti in namestiti na osebni računalnik na več načinov. Več avtorjev, med katerimi so Marshal (2006), Kalezić (2010) in Nema (2014), navaja podobne vrste piratstva programske opreme, ki so kategorizirane na podlagi vira pridobitve ali vira namestitve programske opreme. Vrste piratstva programske opreme, ki

${ }^{36}$ Med temi zakoni so najpomembnejši Zakon o patentih, Zakon o žigih, Zakon o pravni zaščiti industrijskega dizajna, Zakon o avtorski in sorodnih pravicah ter ostali zakoni na področju avtorskega prava (Simić 2015).

${ }^{37}$ Službeni glasnik Republike Srbije, št. 85/2005, 88/2005, 107/2005, 72/2009, 111/2009, $121 / 2012,104 / 2013$ in 108/2014. 
jih navajajo navedeni avtorji, smo vsebinsko združili v naslednje kategorije:

- Mehko nalaganje (angl. softlifting) - pri tem je značilno, da zakonito kupljeno različico programske opreme namesti več uporabnikov, kot to dovoljuje licenca programske opreme. Najpogosteje se ta vrsta piratstva pojavlja med prijatelji, ki si izmenjujejo program na elektronskih nosilcih podatkov, ali v službah, v katerih podjetje kupi licenčno različico programske opreme, ki jo pozneje zaposleni nezakonito namestijo na svoje računalnike.

- Ločevanje (angl. unbundling) - pri tem je značilno, da trgovci programsko opremo, katere licenca in pogoji proizvajalca določajo, da je namenjena prodaji s točno določeno strojno opremo, odvzamejo in jo prodajo kot samostojno ali $\mathrm{z}$ drugo strojno opremo.

- Ponarejanje (angl. counterfeiting) - za to je značilno, da se izdela enaka kopija programske opreme s pripadajočo dokumentacijo in embalažo ter se takšna nameni prodaji končnemu kupcu. Craig, Honick in Brunett (2005) pri tem podajajo primer vloma v Microsoftovo skladišče programske opreme, v katerem ni bil odtujen niti en primerek od mnogoštevilnih nosilcev elektronskih podatkov z operacijskim sistemom Windows. Odtujeni so bile predvsem hologramske nalepke in certifikati avtentičnosti proizvoda, pri čemer poudarjajo, da pirati zlahka ponaredijo programsko opremo, precej zahtevnejše pa je ponarediti holograme, s čimer so računalniški pirati lahko dosegli višje cene na trgu.

- Nalaganje na trdi disk (angl. hard disc loading) - za to velja, da piratsko programsko opremo na računalnik namestijo trgovci z računalniško opremo $\mathrm{z}$ namenom povečanja prodaje oziroma doseganja nižje cene računalnika na trgu. Pri tem niti ni nujno, da se kupci zavedajo protizakonitega trgovčevega početja. ${ }^{38}$

- Oddajanje (angl. renting) - pri tem je značilno, da najemodajalec programsko opremo da v najem, čeprav licenčna pravila to prepovedujejo. ${ }^{39}$ Z A S P v 113. členu natančneje opredeli, da ima izključno avtor pravico do distribuiranja računalniškega programa, vključno

\footnotetext{
${ }^{38}$ Posebno pozornost je treba nameniti spletnim nakupom računalniške opreme v mednarodnih spletnih trgovinah.

${ }^{39}$ Pravica dajanja v najem je zakonsko opredeljena v Z ASP, ki v 26. čl. določa izključno avtorjevo pravico dajanja avtorskega dela $v$ najem.
} 
s pravico dajanja v najem, pri čemer to pravico z licenčno pogodbo lahko prenese na tretjo osebo.

- Internetno piratstvo (angl. internet piracy) - pri tem je značilno, da se piratska programska oprema na uporabnikov računalnik prenese neposredno s strežnikov, dostopnih prek spletnih povezav, ali s pomočjo namenskih programov za prenašanje datotek (P 2 P), kar pomeni neposredno iz računalnikov drugih uporabnikov omrežij P2P.

Glede na razsežnost in kompleksnost problematike internetnega piratstva bomo to vrsto podrobneje obravnavali v nadaljevanju.

\section{Internetno piratstvo}

Sodobno internetno piratstvo je svojo intenzivno rast začelo v poznih devetdesetih letih 20. stoletja s pojavom aplikacij, kot so Napster, ${ }^{40}$ Gnutella, ${ }^{41}$ Kazaa, ${ }^{42}$ Entropy, ${ }^{43}$ eMule ${ }^{44}$ in podobnimi. Pozneje pa se je število prenosov piratske programske opreme in drugih avtorsko zaščitenih vsebin le še povečevalo, kar je omogočal razvoj tehnologije prenosa digitalnih podatkov, razvoj omrežij P 2 P in novih programskih aplikacij, ki so v internetnem prostoru prisotne še danes (Dahlstrom idr. 2006).

Piratsko programsko opremo uporabniki najpogosteje prenašajo $\mathrm{s}$ pomočjo internetnega omrežja (Cvitkovič 2004, 11-12). Prenos podatkov se lahko izvede neposredno z internetnih strežnikov, na katerih datoteke gostujejo s t.i. sistemom uporabnik/strežnik (angl. client/server), ali neposredno $\mathrm{z}$ uporabo namenske programske opreme, ki omogoča prenos podatkov neposredno $\mathrm{z}$ računalnikov drugih uporabnikov omrežja P 2 P.

Piratsko programsko opremo, ki jo uporabniki prenašajo in delijo, najpogosteje priskrbijo dobro organizirane in strukturirane skupine, imenovane "warez « ${ }^{45}$ (Craig, Honick in Brunett 2005). Skupine »warez« so običajno organizirane v piramidnem sistemu, in sicer tako, da v vrhu

\footnotetext{
${ }^{40}$ Aplikacija Napster (http://ca.napster.com/), ki je delovala na osnovi omrežij P 2 P za izmenjavo podatkov, je imela od leta 1999 do leta 2001, ko so jo ugasnili, več kot 10 milijonov uporabnikov (Dahlstrom idr. 2006).

${ }^{41}$ Glej https://sourceforge.net/projects/gtk-gnutella/.

${ }^{42}$ Glej http://kazaa-lite.en.softonic.com/.

${ }^{43}$ Glej http://entropyproject.net/.

${ }^{44}$ Glej http://www.emule-project.net/home/perl/general.cgi?l=1.

${ }^{45}$ Termin »warez« se uporablja v povezavi s spletnim piratstvom in najpogosteje predsta-
} 
organizacije delujejo dobavitelji, ki pogosto pridobijo nezakonito digitalno vsebino, še preden je ta uradno izdana prek proizvajalca. Pridobljene digitalne vsebine nato s pomočjo sodelavcev, ki delujejo v piramidno organizirani strukturi, ustrezno pripravijo in dajo na voljo široki internetni populaciji (Chaudhry idr. 2010). Vsekakor se nam pojavi vprašanje, kako skupine "warez« uspejo pridobiti programsko opremo še pred njeno prodajo.

S tem vprašanjem so se ukvarjali Craig, Honick in Brunett (2005), ki so opravili obsežno raziskavo delovanja skupin »warez«. Metode pridobivanja programske opreme so umestili v sedem kategorij:

- Programsko opremo zagotovijo osebe, zaposlene pri programski hiši izdajateljici programa (t.i. »insiderji«), ali pa osebe, ki so v stiku s proizvajalcem programske opreme, in jo nezakonito odtujijo. To so na primer lahko kurirji, ki opravljajo poštne storitve, zaposleni v distribucijskih hišah, ki programsko opremo pripravljajo za prodajo, ali osebe, ki prejmejo izdajo programske opreme za namene testiranja.

- Goljufija s kreditnimi karticami, ki se uporabljajo predvsem pri nakupu avtorsko varovane programske opreme, dosegljive s prenosom prek spleta. Goljufija poteka tako, da kupec programske opreme od vdiralcev (angl. hackers) ${ }^{46}$ pridobi nezakonito odtujene podatke kreditne kartice oškodovanca, nato pa prek anonimizacijskih omrežij (najpogosteje omrežij V P N ${ }^{47}$ ali T O ${ }^{48}$ ) izvede plačilo programske opreme in jo prenese na svoj računalnik. Prenos izvršijo, še preden se prodajalec zave, da je bilo uporabljeno nezakonito plačilno sredstvo.

vlja skupine, ki nezakonito pridobijo programsko opremo ali druge digitalne avtorsko zaščitene izdelke ter jih postavijo na splet $\mathrm{z}$ namenom nezakonite distribucije, pri čemer za svoje delo največkrat ne prejmejo plačila. Večkrat se v terminologiji piratstva digitalnih vsebin uporablja tudi izraz "scena" ali "warez scena" (Chaudhry idr. 2010).

${ }^{46}$ ISlovar (2016) hekerja (vdiralca) opredeli kot računalniškega zanesenjaka, »ki spreminja strojno in/ali programsko opremo na izviren, samosvoj način za doseganje novih, nepredvidenih zmožnosti«.

${ }^{47}$ Navidezno zasebno omrežje V P N (Virtual Private Network) ISlovar (2016) opredeli kot "navidezno omrežje, ki s tuneliranjem omogoča vzpostavitev varnejše zasebne povezave v okviru javne komunikacijske infrastrukture«.

${ }^{48}$ TOR (The Onion Router), ki med pošiljateljem informacije in njenim prejemnikom vzpostavi najmanj tri vmesne točke, pri čemer se prejemniku informacije izkaže z IPnaslovom zadnjega vmesnega strežnika (McCoy idr. 2008, 69). 
- F T P $^{49}$ (File Transfer Protocol) vohljanje - pri tem organizacije "warez« razvijajo namensko programsko opremo za pregled vsebine in sprememb na strežnikih F T P-proizvajalcev programske opreme. Tak pregled izvajajo predvsem $v$ imenikih, v katerih zaposleni shranjujejo nove izdaje programske opreme in jih prek protokola F TP pošiljajo razvijalcem na oddaljene lokacije. Tako organizacije »warez« pridobijo največje količine programske opreme, ki jo pozneje distribuirajo prek internetnega omrežja. Še posebej pomembno pa je, da na strežnikih F T P pridobijo tudi druge pomembne programske komponente, kot so izvorna koda programa, licenčne datoteke in drugi zaupni podatki izdajatelja programske opreme, ki jih uporabijo pri nezakoniti distribuciji slednje.

- Socialni inženiring ${ }^{50}$ - to je bila pogosto uporabljena metoda, predvsem za nezakonito pridobivanje računalniških iger, in sicer tako, da so organizacije "warez" in njihovi dobavitelji ustvarili lažne spletne strani, na katerih so se predstavljali kot revije za ocenjevanje računalniških iger. Tako so od proizvajalca programske opreme pridobili izvod programa (igre) za namen ocenjevanja in objave recenzije $v$ reviji še pred uradno izdajo programa.

- Poskusne različice so zelo zaželene pri skupinah "warez«, saj gre v večini primerov za popolnoma delujočo različico programa s spremenjenimi licenčnimi pogoji, ki največkrat določajo časovno omejitev uporabe programa. Skupine "warez« takšne različice $\mathrm{z}$ uporabo socialnega inženiringa najpogosteje pridobijo neposredno od proizvajalcev programske opreme. Omejeno in zaščiteno različico programa nato pošljejo krekerju (angl. cracker), ki prilagodi oziroma spremeni licenco programa, tako da ta deluje s polno funkcionalnostjo.

- Običajen, zakoniti nakup - programska oprema (večinoma igre) ne nastopi prodaje na vseh trgih hkrati. Dobavitelji skupin "warez« želijo kupiti polno različico programa $\mathrm{v}$ čim krajšem času $\mathrm{z}$ name-

\footnotetext{
${ }^{49}$ Protokol za prenos datotek (File Transfer Protocol - FTP) ISlovar (2016) definira kot "protokol v protokolnem skladu T CP/IP za prenos datotek med omrežnimi vozlišči«.

${ }^{50}$ Informacijski pooblaščenec socialni inženiring opredeljuje kot vrsto goljufije, pri čemer napadalec $\mathrm{z}$ uporabo tehnik prepričevanja in manipulacije $\mathrm{z}$ ljudmi od žrtve pridobi zaupne podatke, ki jih najpogosteje uporabi za pridobivanje protipravne premoženjske koristi (Informacijski pooblaščenec 2009). V hujših primerih napadalec s pridobljenimi podatki žrtvi celo grozi ali jo izsiljuje.
} 
nom, da jo prvi postavijo na svetovni splet. Piratska različica programa je pogostoma izdana $v$ šestih urah od njenega nakupa. V tem primeru gre večkrat za tekmovanje med skupinami »warez«, pri čemer zmaga pomeni predvsem prestiž.

- Vdor v informacijski sistem ${ }^{51}$ (angl. hacking) - vdiralec vdre v informacijski sistem izdajatelja programske opreme in tako nezakonito odtuji zadnjo različico izvorne kode programa. $V$ praksi je to najredkeje uporabljen način dobave programske opreme.

Ko skupine »warez« pridobijo nezakonite različice delujoče programske opreme, jih skušajo v čim krajšem času prenesti do njenih končnih uporabnikov. Skupine "warez« so skrbno strukturirane, s hierarhično organizacijo članov in organizirane tako, da njihovi člani natančno vedo, katere so njihove naloge (Albanese 2011, 23). Kljub dejstvu, da skupine "warez« svoja dejanja opravičujejo s tekmovanjem in $\mathrm{z}$ neprofitnim motivom, je treba poudariti, da nezakonite različice programske opreme prihodnjim uporabnikom in prodajalcem priskrbijo po dejanski ničelni ceni (Hill 2007). Tako posredno ustvarjajo prihodke vsaj tistim, ki nezakonito pridobljene različice programske opreme prodajajo na črnem trgu (Albanese 2011, 23). Skupine »warez neposredno ustvarjajo prihodke tudi s prikazovanjem oglasov na t.i. spletnih straneh »warez« (Digital Citizens Alliance 2014).

Hitre internetne povezave in tehnologija P 2 P omogočajo, da nezakonito pridobljeni program doseže milijone uporabnikov v nekaj urah. Organizirano delovanje skupin »warez " poteka tako, da v prvem koraku dobavitelji pridobijo piratsko programsko opremo po enemu izmed opisanih načinov. To programsko opremo, najpogosteje s pomočjo strežnikov F T P, dostavijo drugemu nivoju, ki ga v piramidni strukturi poimenujemo izdajatelji (angl. release groups) (Albanese 2011). Izdajatelji navadno po prejemu piratske vsebine s pomočjo uporabe tehnologije IRC (Internet Relay Chat) piratsko vsebino razdelijo širšemu krogu poznanih uporabnikov, imenovanih povezovalci (angl. facilitators). Ti omogočijo, da je piratske vsebine mogoče najti z namenskimi spletnimi iskalniki, poleg tega pa $z$ zmogljivimi internetnimi povezavami priskrbijo zadostno število končnih uporabnikov, ki pozneje s pomočjo omrežij P 2 P delujejo sočasno kot odjemalci in ponudniki piratske programske

\footnotetext{
${ }^{51}$ Napad na informacijski sistem je kaznivo dejanje, določeno v 221. čl. KZ-1, pri čemer se kot izvršitvena oblika šteje vdor v informacijski sistem ali prestrezanje podatkov v informacijskem sistemu.
} 


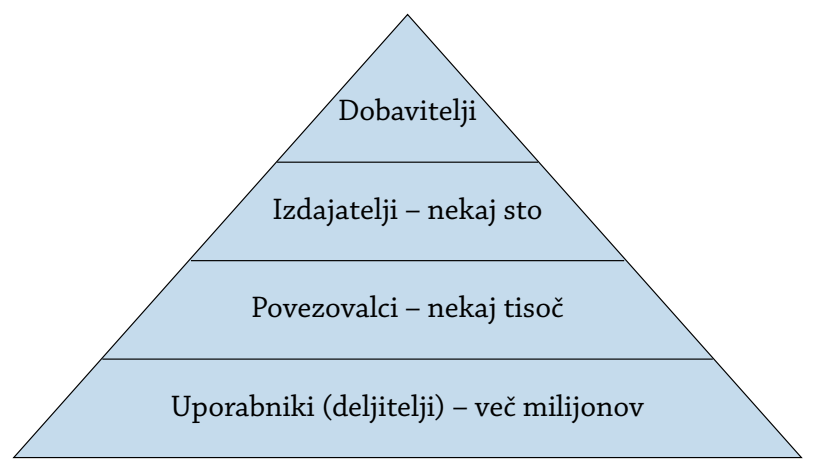

Slika 2.1 Piramida internetnega piratstva (povzeto po Chaudhry idr. 2010, 4)

opreme (Albanese 2011). Da bi se izognili pregonu, nezakonite različice programske opreme predelajo tako, da jih izdajatelji in povezovalci večkrat preimenujejo in sočasno naložijo na več hitrih strežnikov, s čimer se zabriše sled nalaganja prvotno naložene vsebine. Ko število izvodov prenesene programske opreme doseže najširšo populacijo, je izsleditev tistih, ki so datoteke prvotno naložili, dejansko nemogoča (Chaudhry idr. 2010).

Na sliki 2.1 prikazujemo piramido internetnega piratstva, ki prikazuje razmerja udeležencev $\mathrm{v}$ verigi spletnega piratstva.

\section{Arhitektura omrežij za prenos datotek}

V osnovi se za prenos večjih datotek v internetnem omrežju najpogosteje uporabljata dve arhitekturi omrežij. $V$ prvem primeru gre za klasičen sistem odjemalec - strežnik, pri katerem se podatki nahajajo na strežniku, kamor jih je naložil upravitelj vsebin. V drugem primeru se digitalne vsebine nahajajo na pomnilniških medijih posameznih uporabnikov omrežja in se s pomočjo namenskih programov prenašajo neposredno med uporabniki (Maly 2003, 6).

Pri sistemu odjemalec - strežnik odjemalec podatke najde prek spletnega iskalnika (Cvitkovič 2004, 11), vsebino pa si prenese s pomočjo internetnega brskalnika, kot je program Firefox ali Chrome (Maly 2003, 6). Večina zakonito gostujočih vsebin je dostopna na javnih spletnih strežnikih, s katerih si jih odjemalec prenese brezplačno ali proti plačilu, če pogoji tako določajo.

Sistem odjemalec - strežnik po svoji zasnovi vsekakor omogoča tudi prenos nezakonito naloženih digitalnih vsebin, v našem primeru pirat- 
ske programske opreme. Najbolj poznan strežnik, ki je gostoval nezakonite digitalne vsebine, je bil poimenovan Megaupload.com. ${ }^{52}$ Njegova posebnost je bila ta, da gostujočih datotek ni bilo mogoče najti s klasičnimi iskalniki ali na spletnih straneh gostujočega strežnika, ampak so se informacije o vsebinah izmenjevale neposredno med uporabniki strežnika ali prek objav spletnih povezav, najpogosteje na spletnih forumih (Peukert, Clausen in Kretschmer 2015). Uporabniki, ki so na strežnik Megaupload.com naložili digitalne vsebine, so prejeli spletno povezavo do gostujočih vsebin, ki so jo delili med internetnimi uporabniki ter jim tako omogočili dostop do piratskih vsebin. Takšna rešitev, ki je ločevala gostujoče vsebine od deljenja povezav do njih, je bila od lastnikov strežnika sprejeta prav zaradi gostovanja nezakonitih vsebin. Lastniki strežnika so se tako skušali umakniti od piratskih vsebin, ki so gostovale na strežniku, kar pa jih ni rešilo pred mednarodnim kazenskim pregonom in končnim zaprtjem strežnika v mesecu januarju 2012 (Peukert, Clausen in Kretschmer 2015).

Sistem odjemalec - strežnik ima zaradi svoje zasnove prednosti in slabosti. Maly (2003, 7-8) je prednosti opredelil na naslednji način:

- upravljanje podatkov je preprosto, saj se nahajajo na eni lokaciji;

- preprosto določanje administratorskih in uporabniških pravic;

- hitro ustvarjanje varnostnih kopij in učinkovito upravljanje odprave napak;

- strojna oprema strežnika je prilagojena za hitro obdelavo zahtev odjemalca;

- obdelava podatkov poteka neposredno na strežniku, tako da je obremenitev omrežja manjša;

- ob okvarah pri odjemalcu je hiter dostop do lastnih podatkov na strežniku.

Slabosti sistema pa je Maly (2003, 7-8) opredelil na naslednji način:

- potrebna sta neprestan nadzor in vzdrževanje sistema;

- visoki stroški vzdrževanja sistema;

- centralizacija vseh podatkov na enem strežniku, pri čemer okvara, izpad ali zaprtje strežnika navadno povzroči celotno ali delno nezmožnost delovanja sistema.

\footnotetext{
${ }^{52}$ Strežnik je med največjo aktivnostjo zasedal tudi do $4 \%$ celotnega internetnega podatkovnega prometa (Peukert, Clausen in Kretschmer 2015, 4).
} 
Slika 2.2

Shema omrežja odjemalec strežnik (model Megaupload, Rapidshare; $\square$ - uporabnik, 으 - podatkovni strežnik, 은 - strežnik s podatki o povezavi do vsebine; $\rightarrow$ prenos datoteke, -- informacija o datoteki; povzeto po Klumpp 2013, 20)

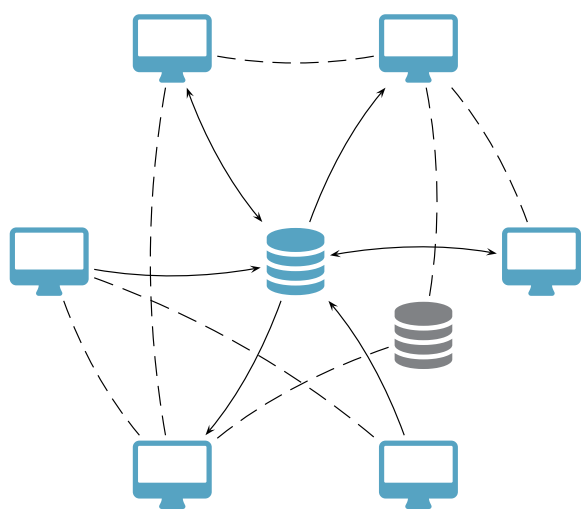

V internetnem prostoru je še vedno na voljo veliko strežnikov, ki omogočajo gostovanje piratske programske opreme ${ }^{53}$ in delujejo po sistemu odjemalec - strežnik.

Preprečevanje deljenja piratskih vsebin na internetu je v praksi danes nemogoče. To je posledica širine internetnega prostora, ki je ni mogoče nadzirati. Z zaprtjem strežnikov, na katerih so gostovale piratske vsebine, se sicer začasno oteži dostopnost do nezakonitih digitalnih vsebin, vendar se pojavljajo vedno novi strežniki z novimi rešitvami, ki nadomestijo zaprte (Arnold idr. 2014).

Na sliki 2.2 prikazujemo delovanje sistema odjemalec - strežnik, kot je ta deloval v primerih strežnikov Megaupload.com in Rapidshare.com, ki sta bila pretežno namenjena deljenju piratskih digitalnih vsebin.

V drugi sistem uvrščamo omrežja P 2 P, za katera je značilno, da delujejo brez centralnega spletnega strežnika, kar pomeni, da gre za decentraliziran sistem, pri čemer si uporabniki omrežja vsebine prek internetne povezave prenašajo neposredno med seboj (Maly 2003, 6). Vsak računalnik v omrežju tako deluje kot strežnik in odjemalec hkrati. Cvitkovič (2004) je tak sistem poimenoval »sistem enakovrednih računalnikov«, pri čemer je izhajal iz jezikovne razlage sistema in samega delovanja.

Poimenovanje sistema enakovrednih računalnikov je sicer treba dopolniti, saj tu ne gre za klasično mrežo medsebojno povezanih računal-

\footnotetext{
${ }^{53}$ Preverili smo povezave do vsebine nekaterih strežnikov, ki na dan 1. 3. 2016 hranijo tudi piratske digitalne vsebine, čemur v osnovi niso namenjeni. Ti strežniki so poimenovani kot: filecrypt.cc, filefactory.com, uploaded.to in delujejo na enakem principu, kot je deloval megaupload.com.
} 
nikov. Cvitkovič (2004) zato dodaja, da je za opredelitev omrežja P 2 P treba izpolniti še dodatne pogoje, in sicer da:

- je mogoče kljub dodeljenemu začasnemu naslovu IP ${ }^{54}$ vzpostaviti povezavo $\mathrm{z}$ drugimi uporabniki;

- so vsi računalniki v omrežju samostojni (tudi računalniki na robovih omrežja);

- so si lastniki računalnikov, ki nastopajo v omrežju, med seboj nepoznani.

Sama omrežja P 2P niso zasnovana izključno za prenos nezakonitih digitalnih vsebin. Kljub temu pa so zaradi arhitekture in razvoja hitrosti spletnih povezav bistveno pripomogla k povečani izmenjavi piratskih digitalnih vsebin med uporabniki (Klumpp 2013).

Maly $(2003,5)$ je prednosti omrežja P 2 P opredelil na naslednji način:

- decentralizacija podatkov, ki onemogoča izpad celotnega omrežja;

- izkoristiti je mogoče neizrabljene zmogljivosti računalniške strojne opreme uporabnikov omrežja;

- zaradi porazdelitve podatkovnega prometa po celotnem omrežju ne nastajajo ozka grla;

- večja skalabilnost sistema, kar pomeni preprosto povečanje števila uporabnikov omrežja.

Slabosti omrežja P2P pa Maly $(2003,5)$ opredeljuje na naslednji način:

- ne zagotavlja visokih varnostnih standardov;

- odvisnost omrežja od prisotnosti uporabnikov in vsebin, ki jih delijo;

- internetni iskalniki ne najdejo vsebin, ki se nahajajo pri posameznih uporabnikih.

Yang in Garcia-Molina (2001) omrežja P 2 P delita na dva tipa:

- Hibridni sistem P2P, ${ }^{55}$ za katerega je značilno, da uporabniki omrežja nastopajo kot strežniki in odjemalci popolnoma samo-

${ }^{54}$ ISlovar (2016) I P-naslov opredeljuje kot »logični naslov omrežnega vmesnika računalnika, pri katerem poteka komunikacija prek T C P/I P-ja«. Pri začasnem I P-naslovu ima lahko isti računalnik ob vsakem priklopu v omrežje različen I P-naslov (Cvitkovič 2004, 18-24).

${ }^{55}$ Prvi in najrazširjenejši hibridni sistem P 2 P je bil t. i. sistem Napster, katerega delovanje je bilo povezano s centralnim indeksiranjem informacij o vsebini in lokaciji datotek na računalnikih uporabnikov omrežja. Najpomembnejša slabost sistema je bila prav cen- 


\section{Slika 2.3}

Shema omrežja Napster (hibridni sistem P 2P;

$\square$ - uporabnik,

으- podatkovni strežnik,

$\rightarrow$ prenos datoteke,

- - informacija o datoteki;

povzeto po Klumpp 2013, 4)

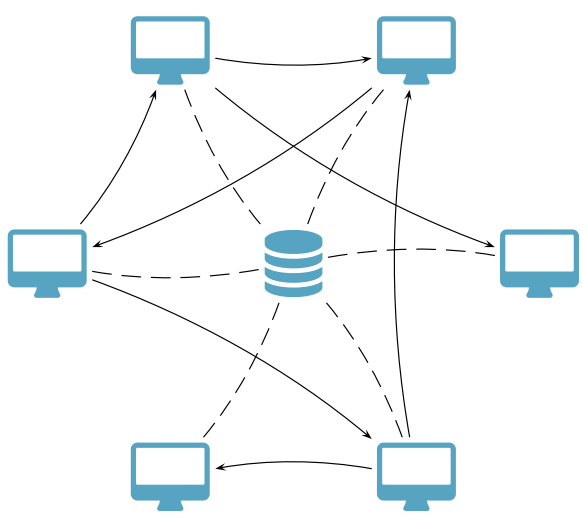

stojno. Podporo pri delovanju nudijo vmesni strežniki, na katerih so predvsem informacije, ki so potrebne za koordinacijo, podporo in za usklajenost delovanja sistema P 2P (kot je prikazano na sliki 2.3).

- Čisti sistem P 2P, za katerega je značilno, da uporabniki omrežja nastopajo kot strežniki in odjemalci popolnoma samostojno in enakovredno brez vmesnih strežnikov, ki bi kakor koli koordinirali, usklajevali ali nudili podporo delovanju omrežja P 2 P.

Čisti sistem P 2P je nasledil hibridni sistem P 2P (Agarwal, Bansal in Gupta 2013). Tako je odpravil centralno indeksiranje podatkov o vsebinah, ki so na računalnikih uporabnikov omrežja (prav tam). Z njegovim razvojem so se pojavila namenska omrežja za izmenjavo datotek, med katerimi je bilo najbolj poznano omrežje imenovano Fasttrack; za njegovo uporabo se je najpogosteje uporabljala aplikacija Kazaa ${ }^{56}$. Zaradi prekomerne porabe podatkovnega prometa je omrežje Fasttrack postalo počasno, zato so aplikacije za delovanje v tem omrežju med uporabniki postale nepriljubljene (Backx idr. 2002).

Arhitektura čistega sistema P 2P je shematsko prikazana na sliki 2.4. Trenutno najbolj uporabljen sistem za izmenjavo digitalnih vsebin prek internetnega omrežja je sistem »bittorrent ${ }^{57}$ (Fuchs 2015). Gre za napredni hibridni sistem P2P, ki odpravlja slabosti sistema P2P s

tralizacija indeksa vsebin na enem centralnem strežniku, ki je bil po odločitvi sodišča zaprt, kar je posledično pomenilo konec omrežja Napster (Agarwal, Bansal in Gupta 2013).

${ }^{56}$ Glej http://kazaa-lite.en.softonic.com/.

${ }^{57}$ Glej http://www.bittorrent.com/. 
Slika 2.4

Shema čistega omrežja P 2 P

$(\square-$ uporabnik, $\rightarrow$ prenos

datoteke, - - informacija

o datoteki; povzeto

po Klumpp 2013, 7)

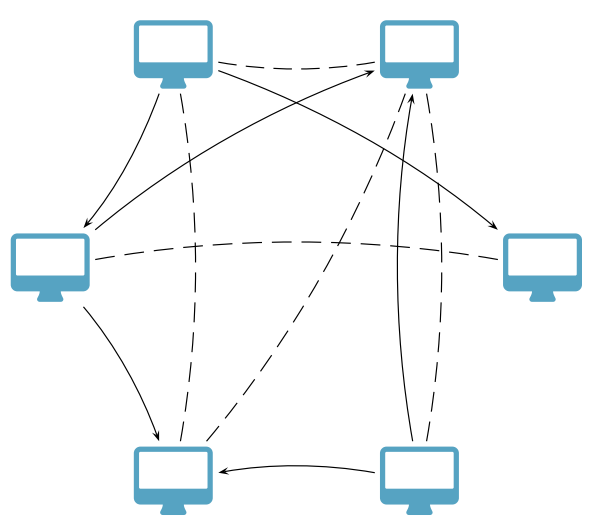

centralnim informacijskim strežnikom. Uporabniki sistema »bittorent« si informacije o lokaciji datotek in njihovi vsebini pridobijo tako, da si na svoj računalnik prenesejo t. i. datoteko »torrent« $\mathrm{z}$ različnih spletnih strani oziroma strežnikov (Klumpp 2013, 13). Strežniki, ki vsebujejo datoteke »torrent«, so lahko med seboj tudi povezani, kar odpravlja pomanjkljivost klasičnega hibridnega P 2 P-sistema. Po pridobitvi datoteke "torrent « si uporabnik $\mathrm{z}$ uporabo namenskih programov ${ }^{58}$ (angl. torrent clients) začne prenašati digitalne vsebine neposredno od drugih uporabnikov programov »torrent " (Klumpp 2013, 13).

Protokol »torrent« deluje tako, da se posamezna datoteka deli med uporabniki omrežja v roju (angl. swarm) (Buford, Yu in Lua 2009). Večje datoteke program razdeli na več manjših delov, ki se posamično prenašajo med soležniki v roju. Ko si uporabnik prenese že prvi zaključeni del posamezne datoteke, se ta del začne takoj oddajati drugemu soležniku v povezanemu roju (Klumpp 2013, 13) (slika 2.5). Prav zaradi takšnega načina delovanja je protokol »torrent« trenutno najprimernejši sistem za prenos večjih datotek. Tako je bil leta 2015 kickass.to, ${ }^{59}$ ki trenutno gostuje v Somaliji, najbolj obiskan strežnik, saj je bilo vsako uro nanj na novo naloženih 250 datotek »torrent« (Fuchs 2015). Poleg kickass.to sta javno poznana strežnika, kjer gostujejo datoteke »torrent«, The Pirate Bay $^{60}$ in Isohunt ${ }^{61}$ (Van der Sar 2016).

Seveda se pojavljajo vedno novi strežniki, zaradi česar sta pregon in

\footnotetext{
${ }^{58}$ Programi za prenos datotek torrent so prosto prenosljivi programi, ki jih pridobimo na internetu; trenutno so v uporabi programi z imeni uTorrent, Vuze, Bitlord in BitComet.

${ }^{59}$ Glej https://kat.cr/.

${ }^{60}$ Glej https://thepiratebay.se/.

${ }^{61}$ Glej https://isohunt.to/.
} 


\section{Slika 2.5}

Shema naprednega hibridnega omrežja ( $\square$ - uporabnik, 结-podatkovni strežnik,

$\rightarrow$ prenos datoteke, - - informacija o datoteki; povzeto po Klumpp 2013, 6)

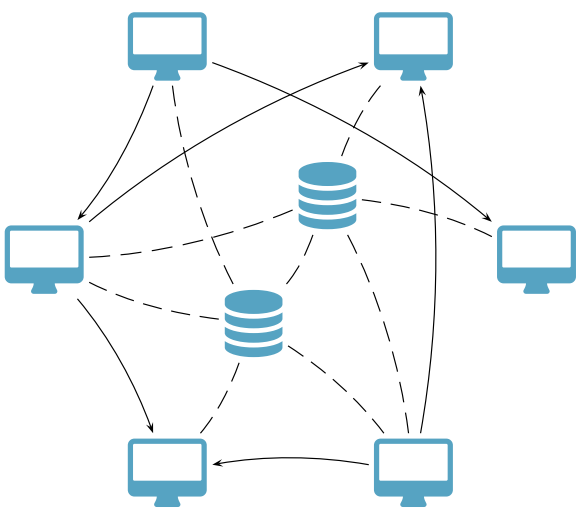

zaprtje posameznih tovrstnih strežnikov zaradi zlorabe avtorsko zaščitenih vsebin neučinkovita.

\subsection{Vzroki za povpraševanje po piratski programski opremi}

Dostopnost do svetovnega spleta in razvoj hitrih širokopasovnih povezav sta v zadnjem desetletju številnim uporabnikom omogočila izjemno velike možnosti prenosa vsebin na svoj računalnik. Uporabniki piratske programske opreme se sicer načelno zavedajo nezakonitosti svojega početja, vendar se to početje pri večini populacije razume kot družbeno sprejemljivo (Logsdon, Thompson in Reid 1994). Verjetno se redki uporabniki pri takem početju sprašujejo o pravicah avtorja, ki mu jih podeljuje zakonodaja, bolj problematično pa je, da nimajo moralnih ali etičnih zadržkov pri svojem početju (Lau 2003). Vsebine, ki so dostopne $\mathrm{v}$ internetnem prostoru, uporabniki razumejo kot javno in prosto dostopne ter se tako tudi obnašajo. Pri tem je posebno zanimivo, da običajni uporabniki programske opreme $v$ navideznem informacijskem svetu zavzamejo poseben odnos do piratstva in pogosto takšno programsko opremo delijo iz občutka solidarnosti do drugih udeležencev $\mathrm{v}$ internetnem prostoru (Lau 2003).

Siegfried (2004) je preučeval odnos študentov do piratstva programske opreme, pri čemer je ugotovil, da študentje nimajo etičnih zadržkov pri uporabi piratske programske opreme. Glavni razlogi, zakaj študentje uporabljajo piratsko programsko opremo, so naslednji:

- lastnik avtorske pravice ne izgubi nič - menijo, da avtorju dejansko ne odvzamejo osnovnega proizvoda, ki je še vedno v njegovi posesti; 
Preglednica 2.1 Dejavniki povpraševanja po piratski programski opremi

\begin{tabular}{|c|c|c|}
\hline Dejavniki & & Značilnosti \\
\hline \multirow[t]{4}{*}{ Dejavniki proizvoda } & Vsebina & Privlačna vsebina \\
\hline & Kakovost & $\begin{array}{l}\text { Visoka kakovost kopije, } \\
\text { dejansko enaka izvirniku }\end{array}$ \\
\hline & Uporaba in shranjevanje & $\begin{array}{l}\text { Preprosta uporaba in shra- } \\
\text { njevanje piratskih vsebin }\end{array}$ \\
\hline & Cena & Nizka ali ničelna cena \\
\hline \multirow[t]{3}{*}{ Individualni dejavniki } & Razpoložljivi dohodek & $\begin{array}{l}\text { Nizki razpoložljivi do- } \\
\text { hodki za nakup program- } \\
\text { ske opreme }\end{array}$ \\
\hline & Zavedanje nevarnosti & $\begin{array}{l}\text { Nizka stopnja zavedanja } \\
\text { o nevarnosti zlonamerne } \\
\text { programske opreme }\end{array}$ \\
\hline & Odnos do piratstva & $\begin{array}{l}\text { Družbena sprejemljivost } \\
\text { uporabe piratskih vsebin }\end{array}$ \\
\hline \multirow[t]{2}{*}{ Tržni dejavniki } & Dostopnost & $\begin{array}{l}\text { Široka dostopnost do digi- } \\
\text { talnih piratskih vsebin }\end{array}$ \\
\hline & Tržno tveganje & $\begin{array}{l}\text { Neučinkovita pravna za- } \\
\text { ščita, pomanjkanje starše- } \\
\text { vskega nadzora }\end{array}$ \\
\hline
\end{tabular}

ОР Ом в E Povzeto po Stryszowski in Scorpecci 2009, 54.

- kar je dostopno na internetu, se razume za javno dostopno - pri tem se ne ozirajo na licenčne omejitve uporabe avtorskega dela;

- poštena uporaba ${ }^{62}$ (angl. fair use) kopiranih avtorskih del je upravičena - pri tem študija navaja, da zaradi uporabe sorazmerno majhnega deleža avtorsko zaščitenega dela študentje menijo, da so do tega upravičeni; navajajo še, da s takšno uporabo ne povzročajo nikakršne izgube vrednosti avtorskega dela.

Stryszowski in Scorpecci (2009) sta v okviru študije OE CD opredelila dejavnike, ki vplivajo na povpraševanje po piratski programski opremi. Dejavnike sta razdelila v tri skupine, in sicer na dejavnike, povezane s proizvodom, individualne dejavnike in tržne dejavnike, kar prikazujemo v preglednici 2.1.

Vzroke za povpraševanje po piratski programski opremi so razisko-

${ }^{62}$ Pošteno uporabo (angl. fair use) avtorsko zaščitenih del zakonodaje posameznih držav dovoljujejo, pri čemer je takšna uporaba zakonsko omejena $\mathrm{z}$ dodatnimi pogoji, ki se razlikujejo po posameznih državah (Siegfried 2004, 10). Pošteno uporabo avtorskih del opredeljuje tudi Z A S P v 46. členu zakona. 
vali različni avtorji, ki jih navajamo v nadaljevanju. Zanimivo je, da avtorji prihajajo do zelo podobnih ugotovitev. Karakaya in Ulutürk (2011) sta povzela 28 študij, ki preučujejo dejavnike, ki vplivajo na posameznikovo odločitev o uporabi piratske programske opreme. Dejavnike, ki jih opredeljujejo povzete študije, predstavljamo v nadaljevanju.

\section{Cena programske opreme}

Že osnovna ekonomska teorija na področju povpraševanja in ponudbe postavlja v ospredje povezanost količine in cene, pri čemer se na strani povpraševanja višja cena izdelka odraža v nižji stopnji povpraševanja po njem. Nasprotno velja za ponudbo, pri kateri so pri višji ceni ponudniki pripravljeni ponujati večjo količino izdelkov (Samuelson in Nordhaus 1992, 48-50). Takšno racionalno obnašanje ponudnikov in povpraševalcev se vsekakor odraža tudi na obsegu ponudbe in povpraševanja po komercialni programski opremi, pri čemer na trgu obstaja dodatna anomalija $\mathrm{v}$ obliki ponudbe nezakonitih piratskih digitalnih vsebin, ki izkrivlja tržno ravnovesje. Piratska programska oprema daje povpraševalcem alternativno možnost, tako da lahko programsko opremo dejansko enake kakovosti pridobijo po bistveno nižji ceni ali celo brez dodatnih stroškov. Pri teh pogojih so stroški in porabljen čas za pridobitev in namestitev piratske programske opreme zanemarljivi (Hill 2007, 15).

Hsu in Shiue (2008) sta raziskovala pripravljenost kupcev za plačilo licenčne programske opreme in ugotovila, da $80 \%$ anketirancev razume ceno kot bistveni element odločitve o nakupu programske opreme. Ugotavljata, da kupci vrednotijo komercialno programsko opremo manj, kot znašajo cene na trgu, zaradi česar posegajo po piratski programski oprem. V omenjeni raziskavi avtorja ugotavljata tudi, da večina anketiranih ne razmišlja o prihodnjem nakupu komercialne programske opreme.

Tudi A. Marshal (2006) navaja številne študije, ki soglasno potrjujejo, da sta cena in dohodek gospodinjstva bistvena elementa pri odločanju o nakupu programske opreme, pri čemer poudarja, da je dejavnik cene ključnega pomena predvsem pri nakupnih odločitvah študentov. Spark (2010) pri tem dodaja še, da se nagnjenost k uporabi piratske programske opreme poveča, če se poveča razlika v ceni med komercialno in piratsko različico programa. Ključno vlogo pri odločitvi o uporabi piratske programske opreme ima pri tem tudi dohodek gospodinjstva. Prav zato so začeli proizvajalci programsko opremo ponujati v posebnih izvedbah za študente po nižji ceni $z$ namenom, da bi povečali stopnjo uporabe 
komercialne programske opreme med študentsko populacijo (Siegfried 2004).

\section{Ozaveščenost uporabnikov}

Študije avtorjev glede ozaveščenosti uporabnikov piratske programske opreme, ki jih navajamo v nadaljevanju, se nanašajo predvsem na poznavanje zakonodaje, ki ščiti avtorske pravice. Lau (2003) ugotavlja, da se uporabniki piratske programske opreme pri njenem nameščanju $\mathrm{v}$ večini primerov ne zavedajo kršenja avtorskih pravic. Kot vzrok navaja, da uporabniki ne posvečajo dovolj pozornosti licenčnim pogojem, ki se pri namestitvi programa pojavijo na računalniškem zaslonu. Ugotavlja še, da obstaja močna negativna povezava med poznavanjem avtorskega prava in namero po nezakoniti namestitvi programske opreme. Čeprav proizvajalci programske opreme ozaveščajo uporabnike programske opreme glede obstoja avtorskih pravic na računalniških programih, to ne dosega želenih uspehov (Phau in Ng 2010). Albanese (2011) predlaga, da bi se ozaveščanje uporabnikov programske opreme izvajalo predvsem v obliki izobraževanj na področju avtorskega prava in na področju kazenskopravne zakonodaje v povezavi s kršitvami avtorskih pravic. Izobraževalni proces je treba začeti izvajati z mlajšo populacijo, saj se pri njej lahko vpliva na sprejemanje sistema vrednot. Albanese (2011) meni, da bi bilo treba tudi večkrat javno objaviti primere pregona kršenja avtorskih pravic in sodne epiloge, ki so posledica kršitev avtorskega prava, kar bi preventivno vplivalo na nižjo stopnjo zlorab avtorskih pravic.

\section{Družbeni dejavniki}

Karakaya in Ulutürk (2011) sta v okvir preučevanja družbenih dejavnikov, ki vplivajo na uporabo piratske programske opreme, zaječa več študij, ki se nanašajo na življenjsko in družbeno okolje uporabnikov. Povzela sta študije, ki ugotavljajo, da ima odnos družine in prijateljev do piratstva programske opreme na posameznika zelo velik vpliv v smislu odobravanja in zavračanja uporabe.

Do enakih ugotovitev prihaja Siegfried (2004), ki je preučeval odnos študentov do piratstva programske opreme in ugotovil, da se študentje ne zavedajo pomena kršenja avtorskih pravic oziroma pridobivanja in uporabe piratske programske opreme ne zaznavajo kot kršitve. Med študenti se izoblikuje okolje, ki odobrava nalaganje in uporabo piratske programske opreme. Siegfried (2004) dodaja, da ima takšno okolje neposreden vpliv tudi na posameznika in njegov odnos do piratstva pro- 
gramske opreme. Dodaja še, da imajo študentje prav tak odnos tudi pri kopiranju drugih avtorskih del, ki se izvajajo v okviru študijskega procesa.

\section{Tveganje kaznovanosti}

Država predpisuje pravne norme $\mathrm{z}$ namenom urejanja medsebojnega delovanja subjektov v pravno pomembnih družbenih razmerjih (Pavčnik 2015, 92). Avtorjem oziroma imetnikom avtorskih pravic so podeljene izključne pravice, ki izvirajo iz avtorstva intelektualne stvaritve, njihovo kršenje pa je protizakonito (Ovčak Kos 2015). Za kršitve teh pravic je predpisana odškodninska in tudi kazenska odgovornost (Z AS P). Kršenje avtorskih pravic bi skladno z zakonodajo moralo biti sankcionirano. Tan (2002) ugotavlja, da ima na povpraševanje po piratski programski opremi vpliv tudi posamzenikova zaznava tveganja, da ga bo doletela v zakonu zagrožena sankcija.

Zaznano tveganje tako obsega dva elementa, in sicer element negotovosti in element posledic. Nastopi v trenutku, ko kršilca začne skrbeti glede posledic, ki bi nastale zaradi njegovega nezakonitega početja (Liao, Lin in Liu 2010). Pri tem je treba poudariti, da je zaznano tveganje za kaznovanost $\mathrm{v}$ povezavi s piratstvom programske opreme pri uporabnikih zelo nizko, saj v javnosti ni poznanih večjih primerov s končno obsodbo v povezavi s tovrstnim piratstvom (Tan 2002).

$\mathrm{Na}$ podlagi predhodno navedenih študij lahko ugotovimo, da je zaradi nizkega števila $\mathrm{v}$ javnosti znanih obsodb $\mathrm{v}$ povezavi $\mathrm{z}$ dejanji piratstva programske opreme nagnjenost $\mathrm{k}$ uporabi piratske programske opreme večja. Skladno s to trditvijo smo pregledali razpoložljive statistične podatke za Republiko Slovenijo in ugotovili, da je v letih 2013 in 2014 policija podala skupno sedem kazenskih ovadb na pristojna tožilstva v zvezi s kaznivimi dejanji kršenja avtorskih pravic. ${ }^{63}$ Pri tem smo upoštevali, da so bila tovrstna kazniva dejanja izvršena na področju računalniškega piratstva. Tako je policija v letu 2014 končala preiskave v petih primerih suma storitve kaznivega dejanja na podlagi 148. čl. Kazenskega zakonika - Kršitev materialnih avtorskih pravic, pri čemer je $\mathrm{v}$ enem primeru podala kazensko ovadbo, ${ }^{64} \mathrm{v}$ štirih primerih pa poročilo pristojnemu državnemu tožilstvu, ker ni bilo zaznanega utemelje-

${ }^{63}$ Glej http://www.policija.si/baza/kd2013.zip in http://www.policija.si/baza/kd2014.zip.

${ }^{64}$ Kazenska ovadba je bila podana ob utemeljenem sumu predelave računalniškega programa, glej Http://www.policija.si/baza/kd2014.zip. 
nega suma, da je bilo storjeno kaznivo dejanje. V letu 2013 je policija končala preiskave $\mathrm{v}$ dvanajstih primerih suma storitev kaznivih dejanj $\mathrm{s}$ področja kršitev avtorskih pravic, pri čemer je bila $\mathrm{v}$ šestih primerih podana kazenska ovadba, ${ }^{65} \mathrm{v}$ šestih primerih pa poročilo na pristojno državno tožilstvo. Tudi Državno tožilstvo Republike Slovenije (D T RS) je v letih 2013 in 2014 obravnavalo kazniva dejanja na področju kršenja avtorskih pravic, pri čemer je bila večina ovadb zavržena. ${ }^{66}$

\section{Moralni razlogi}

Cronan in Al Rafee (2008) sta v svoji študiji potrdila hipotezo, da se oseba z nižjimi moralnimi vrednotami lažje odloči ta izvrševanje dejanj, povezanih s piratstvom programske opreme. Moralne vrednote opredeljujeta kot osebni občutek krivde posameznika pri izvrševanju dejanj piratstva programske opreme.

Logsdon, Thompson in Reid (1994) so preučevali model moralne intenzivnosti, ki opredeljuje odločitveni proces ob odločitvi za uporabo piratske programske opreme. Dejavnike, ki posamezniku olajšajo odločitev za poseganje po piratski programski opremi, so opredelili kot:

- nizko zaznavanje škode, ki jo povzroča piratstvo programske opreme;

- družba piratstvo programske opreme sprejema kot dopustno (»vsi to počnejo«);

- uporabniki piratske programske opreme ne zaznavajo, da bi z dejanji piratstva komur koli nastala škoda;

- uporabniki piratske programske opreme zaznavajo nizko stopnjo tveganja kaznovanosti, pri čemer se ta zaznava zaradi časovne oddaljenosti še dodatno zmanjša;

- uporabniki piratske programske ne zaznavajo osebne navezanosti na proizvajalce programske opreme;

${ }^{65}$ Kazenske ovadbe na področju računalniškega piratstva so bile podane v primerih utemeljenega suma distribucije, reproduciranja in prodaje računalniške opreme z nelicenčno programsko opremo, glej Http://www.policija.si/baza/kd2013.zip.

${ }^{66} \mathrm{~V}$ letu 2013 je D T R S izdal skupno 83 odločb o končanju postopka v povezavi s kaznivim dejanjem kršenja materialih avtorskih pravic, pri čemer je bilo vloženih 7 neposrednih obtožnih predlogov in 76 zavrženj ovadb, medtem ko je DTRS v letu 2014 izdal 6 odločb, pri čemer je bila vložena 1 neposredna obtožnica, 1 odstop tuji državi, vložena 1 zahteva za preiskavo, v 3 primerih pa je bila ovadba zavržena; glej http://pxweb .stat.si/pxweb/Dialog/varval.asp?ma=1360106s\&ti=\&path=../Database/Dem_soc/13 _kriminaliteta/o1_statistika_toz_sodisc/o1_13601_ovadene_poln_osebe/\&lang=2. 
- uporabniki piratske programske zaznavajo, da škoda, ki jo povzročajo, prizadene le nekaj posameznikov ali proizvajalca programske opreme.

Moralne vrednote posameznika se spreminjajo s časom in glede na delovno okolje. Mlajši posamezniki si lažje opravičujejo svoja neetična dejanja, pri čemer »kraja" programske opreme pri njih ne povzroča moralnega premisleka (Moores in Esichaikul 2011). S staranjem se moralne vrednote posameznika spreminjajo, in sicer v smeri poglobljenega premisleka o tovrstnih dejanjih, kar posledično povzroča nižjo stopnjo uporabe piratske programske opreme pri starejši populaciji. Moores in Esichaikul (2011) ugotavljata tudi, da delovno okolje vpliva na razvoj moralnih vrednot posameznika tako, da okolje, v katerem se pogosto uporablja piratska programska oprema, lahko spodbudi posameznika $\mathrm{k}$ njeni povečani uporabi.

\section{Predhodno vedenje - navade}

Cronan in Al Rafee (2008) sta raziskovala odvisnost med preteklim odnosom posameznika $\mathrm{v}$ povezavi s piratstvom programske opreme in verjetnostjo, da bi ta oseba ponovno posegla po piratski programski opremi. Ugotovila sta, da se bo v prihodnosti oseba lažje odločila za kršitev avtorskih pravic v okviru piratstva programske opreme, če je takšno dejanje v preteklosti že izvršila. Wang in McClung (2011) sta raziskavo še poglobila in ugotovila, da je verjetnost, da bo določena oseba prenesla piratsko programsko opremo $\mathrm{z}$ interneta, precej večja, če je takšno dejanje storila $\mathrm{v}$ zadnjih šestih mesecih, pri čemer sta $\mathrm{v}$ raziskavi izhajala iz teorije načrtovanega vedenja (Theory of Planed Behaviour). Protipiratska propaganda bi po njunem mnenju morala vnesti večji občutek krivde osebam, ki so si že prenesle piratsko programsko opremo. Skladno z ugotovitvami teorije načrtovanega vedenja bi osebam, ki so si v zadnjih šestih mesecih prenesle piratske vsebine, vzbudili večji občutek krivde in bi posledično redkeje posegale po piratski programski opremi. Ob prenosu in nameščanju piratske programske opreme si posameznik pridobi tudi določene izkušnje in znanje. Pridobljene izkušnje prav tako vplivajo na odločitveni proces posameznika pri poseganju po piratski programski opremi (Wang in McClung 2011).

\section{Priložnost (preprostost operacij)}

Jaafar, Ramayah in Teng (2008) ugotavljajo, da je prenašanje piratskih vsebin $\mathrm{z}$ interneta ali njihovo kopiranje precej preprosto, saj imamo za 
to razpoložljive tehnične rešitve $\mathrm{v}$ vsakem računalniku. Za pridobivanje piratskih vsebin sta potrebni le povezava na internetno omrežje in nameščena prostodostopna programska oprema. Programska oprema za prenos piratskih vsebin je preprosta za upravljanje, pri čemer posameznik zaradi načina zakupa prenosa internetnih podatkov ne utrpi dodatnih stroškov za prenos piratskih vsebin na svoj računalnik (Tan 2002). Študije, ki jih navajata Karakaya in Ulutürk (2011), še dodatno potrjujejo dejstva, da sta prav razpoložljivost in lahka dostopnost piratskih vsebin tudi dejavnika, ki vplivata na posameznikovo odločitev o namestitvi in uporabi piratske programske opreme. Poleg preprostosti operacij pa moramo upoštevati tudi izkušnje posameznika s področja IK T.

\section{Spol}

Študije, ki sta jih povzela Karakaya in Ulutürk (2011), kažejo na to, da so moški bolj nagnjeni k uporabi piratske programske opreme. Temu pritrjuje tudi Spark (2010), ki povzema številne študije, iz katerih izhaja povezanost dejavnikov spola in nagnjenosti $k$ uporabi piratske programske opreme.

\section{Avtorjeva oddaljenost}

Uporabniki piratske programske opreme lastnika avtorskih pravic pogosto dojemajo kot zelo oddaljeno osebo ali celo bogato monopolno korporacijo; prav zato nimajo občutka, da bi s svojim početjem koga oškodovali (Hill 2007). Siegfried (2004) ugotavlja, da študentje avtorje oziroma proizvajalce programske opreme dojemajo kot oddaljene subjekte, ki jim s kršenjem avtorskih pravic ne nastaja škoda.

Veitch in Constantiou (2011) sta dejavnike, ki vplivajo na odločitev posameznika, kako bo pridobil programsko opremo, umestila v shemo, kot jo prikazujemo na sliki 2.6 .

\subsection{Vzroki za ponudbo piratske programske opreme}

Vzroki za piratstvo programske opreme se pojavljajo tudi na strani ponudbe. Ponudba piratske programske opreme na piratskih medijih (CD, DVD) ali drugih nosilcih digitalnih vsebin je v domeni združb, ki zasledujejo profitni motiv (Albanese 2011). Na internetu je tovrstna ponudba najpogosteje v domeni t.i. scene "warez «, ki v osnovi ne zasleduje profitnega motiva pri distribuiranju piratske programske opreme. Distribucija piratskih vsebin na internetu jim predstavlja predvsem izziv oziroma tekmovanje med posameznimi skupinami »warez«s ciljem, da in- 


\section{Slika 2.6}

Dejavniki vpliva na odločitev o pridobivanju programske opreme (povzeto po Veitch in Constantiou 2011, 6)

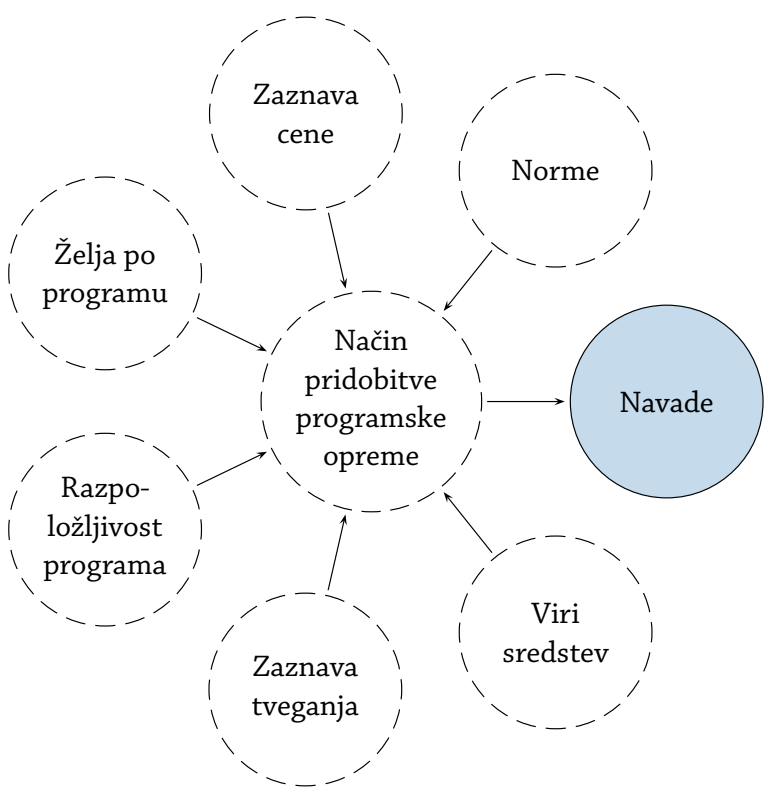

ternetni populaciji prvi ponudijo tovrstno programsko opremo (Craig, Honick in Brunett 2005).

Razvoj IKT je spodbudil spremenjeno obnašanje družbe in posameznikov v navideznem digitalnem okolju (Kizza 2013). Povsem običajni občani v digitalnem okolju podležejo skušnjavi kršenja avtorskih pravic (prav tam). Z razvojem I K T je vsakemu posamezniku dana možnost za izvajanje kršitev ali celo kaznivih dejanj. Kizza (2013) ugotavlja, da na ponudbo piratskih digitalnih vsebin vplivajo prav spremenjene moralne in etične vrednote posameznika v digitalnem okolju. Posameznik podleže vsaj eni izmed sedmih skušnjav, ki vplivajo na ponudbo piratskih digitalnih vsebin:

- Hitrost - digitalno okolje omogoča izjemno hitro pridobivanje ali oddajo avtorsko zaščitenega gradiva, kar zmanjšuje možnosti odkritja, pri čemer kršilci dobijo občutek, da jih ne morejo odkriti.

- Zasebnost in anonimnost - digitalno okolje daje uporabnikom možnost delovanja v popolni anonimnosti $\mathrm{z}$ uporabo ustrezne programske opreme ter tako oblikuje vabljivo okolje za izvajanje prekrškov in kaznivih dejanj, tudi na področju piratstva programske opreme.

- Digitalizacija - preprostost in kakovost kopiranih digitalnih podat- 
kov omogočata dejansko enako kopijo originala, zaradi česar obstaja le malo možnosti, da bi kdo posumil, da ne gre za original, kar spodbuja uporabo ukradenih proizvodov.

- Privlačnost okolja - reševanje programskih izzivov in tekmovanje med skupinami, ki postavijo piratsko programsko opremo na splet, posameznikom predstavljata veliko skušnjavo za vstop v svet piratstva, pri čemer to doživljajo kot izziv in ne kršitev zakonodaje.

- Veliko potencialnih žrtev - posameznik lahko doseže veliko žrtev, pri čemer mu za dodatno potencialno žrtev ni treba vlagati dodatnega truda ali sredstev.

- Mednarodno okolje - kazniva dejanja, storjena v digitalnem okolju, ne poznajo meja in so večkrat storjena v tujih državah. Tako se jih obravnava skladno z zakonodajo države, v kateri je bilo dejanje storjeno, zaradi česar večkrat ne obstajajo tveganja za kazenski pregon storilcev.

- Občutek moči - digitalno okolje daje posamezniku občutek velike moči, kar tudi povsem običajnemu posamezniku predstavlja veliko skušnjavo za storitev dejanj, ki jih običajno ne bi storil.

Stryszowski in Scorpecci (2009) sta v študiji OE CD povzela dejavnike, ki vplivajo na ponudbo piratske programske opreme, ter jih opredelila na podlagi tržnih in tehnoloških dejavnikov ter dejavnikov tveganja. Podrobneje smo dejavnike, kot jih avtorja navajata, opredelili v preglednici 2.2.

\subsection{Možnosti za zmanjšanje stopnje piratstva}

Piratstvo programske opreme povzroča kršenje materialnih avtorskih pravic in vpliva na dohodek imetnikov pravic fizičnih ali pravnih oseb (Lancaster 2004). Z reševanjem problematike piratstva se ukvarjajo proizvajalci programske opreme in organi posameznih držav, pristojni za pregon piratstva programske opreme. Proizvajalci programske opreme trpijo škodo predvsem $\mathrm{z}$ vidika nižjih prihodkov prodane programske opreme, posledično pa je nezanemarljiva tudi posredna škoda, ki jo utrpi celotna družba zaradi manjših vlaganj v razvoj nove programske opreme.

Proizvajalci programske opreme, ki so imetniki avtorskih pravic, so združeni v t.i. protipiratska združenja, pri čemer izvajajo predvsem kampanje, s katerimi ozaveščajo uporabnike programske opreme glede 
Preglednica 2.2 Dejavniki ponudbe po piratski programski opremi

\begin{tabular}{lll}
\hline Dejavniki & Odnos do piratstva & $\begin{array}{l}\text { Značilnosti v prid digital- } \\
\text { nemu piratstvu }\end{array}$ \\
\hline Tržni potencial & $\begin{array}{l}\text { Družbena sprejemljivost } \\
\text { uporabe piratskih vsebin } \\
\text { Vzajemni mehanizmi }\end{array}$ & $\begin{array}{l}\text { Mehanizmi vzpostavitve } \\
\text { vzajemnega vedenja (P 2 P) }\end{array}$ \\
& Dobičkonosnost & $\begin{array}{l}\text { Potencialno sorazmerno } \\
\text { visoka dobičkonosnost }\end{array}$ \\
& Trg & Šrok potencialni trg \\
\hline Tehnologija & Reprodukcija & $\begin{array}{l}\text { Nizki stroški reprodukcije } \\
\text { in visoka kakovost kopije }\end{array}$ \\
& Distribucija & $\begin{array}{l}\text { Družbena sprejemljivost } \\
\text { uporabe piratskih vsebin }\end{array}$ \\
& Pravni okviri & $\begin{array}{l}\text { Permisivno pravo, nezado- } \\
\text { stni pregon }\end{array}$ \\
& & $\begin{array}{l}\text { Pomanjkanje starševskega } \\
\text { nadzora }\end{array}$ \\
\hline Tržno tveganje & Starševski nadzor & \\
& &
\end{tabular}

OP OM B E Povzeto po Stryszowski in Scorpecci 2009, 45.

nezakonitosti in nemoralnosti njihovega početja. ${ }^{67}$ Naslednji ukrepi, ki jih proizvajalci uporabljajo za zaščito avtorskih pravic, so tehnološki ukrepi, ki onemogočajo kopiranje ali neupravičeno uporabo programske opreme (Breznik Močnik idr. 2008). Za zmanjševanje stopnje piratstva si prek pravne zaščite avtorskih pravic in inkriminacije kršitev avtorskega prava na področju piratstva programske opreme prizadevajo tudi države. Te to počnejo tudi s pomočjo ozaveščanja uporabnikov glede nezakonitosti takšnega početja (Vuga 2015).

Piratstvo programske opreme je kompleksen pojav, ki ga je treba reševati na več ravneh. $V$ praksi ne obstaja preprosta rešitev, ki bi omogočila zmanjšanje stopnje piratstva, saj bi bilo za zmanjševanje tako razširjenega pojava treba ukrepati na več ravneh (Castro, Bennet in Andes 2009). K reševanju težav bi tako morali pristopiti vsi deležniki, med katerimi so države, upravljavci spletnih strani, imetniki avtorskih pravic in ponudniki dostopa do spleta (IS P - Internet Service Provider), ki so zmožni vplivati na pojav, pri čemer avtorji Castro, Bennet in Andes (2009) predlagajo, da se s ciljem zmanjšanja stopnje piratstva izvedejo naslednji ukrepi:

\footnotetext{
${ }^{67}$ Glej http://ww2.bsa.org/country/BSA\%2oand\%2oMembers.aspx
} 
- razvoj tehničnih sredstev za zaščito digitalnih vsebin;

- usklajeno ukrepanje imetnikov avtorskih pravic in IS P z razvojem sistemov za opozarjanje kršilcev avtorskih pravic;

- sprejetje zakonodaje in dejavno izvajanje ukrepov mednarodnega pregona kršilcev avtorskih pravic.

V nadaljevanju bomo skušali podrobneje analizirati ukrepe industrije in države za zmanjšanje stopnje piratstva programske opreme. Kot alternativa piratski programski opremi se pojavlja odprtokodna in/ali brezplačna programska oprema. Zato bomo v nadaljevanju kot možnost za zmanjšanje uporabe piratske programske opreme preučili tudi to možnost.

\section{Ukrepi industrije za zmanjšanje stopnje piratstva}

V digitalni dobi je kršenje avtorskih pravic preprosto, saj lahko s preprostimi računalniškimi operacijami pridobimo in namestimo veliko piratske programske opreme. Pravni sistemi posameznih držav normativno sicer regulirajo sistem zaščite avtorskih pravic, vendar sami niso sposobni omejiti stopnje piratstva avtorskih vsebin, med njimi tudi piratstva programske opreme (Logsdon, Thompson in Reid 1994).

Prav zato so se večje gospodarske družbe, ki izdajajo programsko opremo, organizirale v združenja, ki skušajo ozaveščati uporabnike o škodljivosti uporabe piratske programske opreme. ${ }^{68}$ Med osnovne ukrepe, ki so jih programske hiše začele izvajati za zaščito programske opreme, sodijo holografske nalepke, ki se nahajajo na ohišjih medijev (Malhotra 1994). Tovrstna zaščita sicer ne preprečuje kopiranja programske opreme, skuša pa zagotavljati njeno pristnost ob nakupu. Čeprav je za proizvodnjo holografskih nalepk potrebna draga oprema, ponarejevalcem uspeva ustvarjati zelo kakovostne ponaredke.

Proizvajalci programske opreme in založniki drugih digitalnih vsebin so $\mathrm{v}$ svoje izdelke začeli vgrajevati tudi tehnične programske rešitve, katerih namen je zaščita avtorskih del na medijih (Breznik Močnik idr. 2008). S tem ukrepom želijo preprečiti kopiranje vsebin ali uporabo programske opreme, ki ni skladna s svojimi licenčnimi pogoji.

M. Bogataj Jančič (2008) navaja več avtorjev in njihove klasifikacije tehnoloških ukrepov za zaščito digitalnih vsebin. Pri tem ugotavlja, da večina avtorjev tehnološke ukrepe deli v dve večji skupini, in sicer na:

${ }^{68} \mathrm{Glej}$ http://ww2.bsa.org/country/BSA\%20and\%20Members.aspx. 
- ukrepe za nadzor dostopa do zaščitenih avtorskih vsebin;

- ukrepe za nadzor kopiranja.

Najpogosteje uporabljeni sistem za zaščito digitalnih vsebin je t.i. DRM (Digital Rights Management), ki skuša avtorsko vsebino zaščititi z uporabo tehnologije šifriranja (angl. encryption) podatkov, ${ }^{69}$ avtentikacije uporabnika ${ }^{70}$ in zaznavo serijskih podatkov na komponentah strojne opreme (Dahlstrom idr. 2006, 7). Na področju preprečevanja piratstva programske opreme je Microsoft prvi uporabil pristop DRM, in sicer za aktivacijo operacijskega sistema Windows XP, ko je bilo za njegovo aktivacijo treba vnesti aktivacijski ključ (Kovačič idr. 2009). V registracijski ključ so se nato zapisale informacije o strojni opremi, ${ }^{71}$ ki so onemogočale, da bi operacijski sistem namestili na drug računalnik.

Naslednja faza zaščite prenosa digitalnih vsebin je implementacija tehnologije zaupanja vrednega računalništva (angl. trusted computing), ki vsakemu računalniku dodeli digitalni podpis, s katerim se računalnik identificira, pri čemer je digitalna vsebina na njem šifrirana in ne deluje na nobenem drugem računalniku (Kovačič idr. 2009).

Težavo pri tehnoloških ukrepih za zaščito digitalnih avtorskih vsebin M. Bogataj Jančič (2008) vidi v tem, da se $z$ uvedbo zaščitnih ukrepov omejujejo tudi tista dejanja, ki jih avtorsko pravo dovoljuje. Ta dejanja opredeli kot ustvarjanje varnostne kopije in uvedbo mehanizmov za izvajanje nadzora do dostopa ali uporabe avtorskih del, pri čemer ta poseg presega dodeljeno avtorsko pravico.

Sicer pa so na neučinkovitost tehnoloških ukrepov opozorili Biddle idr. (2002), ki so preučevali vpliv temnega spleta (angl. darknet) oziroma nevidnega spleta ${ }^{72}$ (angl. deepnet) na distribucijo piratske programske opreme. Ugotovili so, da tehnološki ukrepi za zaščito programske opreme niso učinkoviti v preprečevanju piratstva, in sicer predvsem zaradi naslednjih razlogov (Biddle idr. 2002):

${ }^{69} \mathrm{Z}$ enkripcijo podatkov postanejo ti šifrirani in posledično neberljivi osebam, ki ne razpolagajo z geslom za dešifriranje podatkov.

${ }^{70}$ Avtentikacija uporabnika pomeni, da se mora sistem prepričati, da je oseba, ki vsebino uporablja, tista, ki ji je bila vsebina namenjena. Najpogosteje se avtentikacija uporabnika izvede s pomočjo vpisa uporabniškega imena in gesla.

${ }^{71} \mathrm{~V}$ registracijski ključ so se vgradile informacije o serijskih številkah trdega diska, procesorja in drugih strojnih komponent (Kovačič idr. 2009).

${ }^{72}$ Nevidni splet (angl. deepnet) je del svetovnega spleta, na katerem klasični internetni iskalniki teh internetnih strani ne odkrijejo (ISlovar 2016). 
- Vsak tehnološki ukrep, ki ga je industrija razvila za zaščito programske opreme, je neučinkovit oziroma ga onesposobijo vdiralci.

- Tehnologija prenosa in izmenjave digitalnih vsebin omogoča, da vsak, ki ima dostop do internetnega omrežja, pridobi piratsko programsko opremo, če obstaja samo ena nezaščitena različica. Zaščita je lahko onemogočena ali pa različica programske opreme zaide na splet še pred uvedbo tehnoloških zaščitnih ukrepov.

- Izmenjavo piratskih vsebin med uporabniki interneta je nemogoče preprečiti, saj ti v skrajnem primeru lahko oblikujejo lastna omrežja za izmenjavo digitalnih vsebin, ki jih ni mogoče nadzirati.

Iz navedenega sklepamo, da tehnološki ukrepi sami po sebi ne nudijo zadostne zaščite avtorskih digitalnih vsebin, saj so jih t. i. hekerji v večini primerov sposobni zaobiti ali onesposobiti. Zaradi tega razloga so zato potrebni tudi drugi ukrepi za preprečevanje piratstva programske opreme, predvsem prek države, kar opisujemo v nadaljevanju.

\section{Ukrepi države za zmanjšanje stopnje piratstva}

Država ima več vzvodov, s katerimi lahko vpliva na zmanjšanje stopnje piratstva programske opreme. Svoje poslanstvo izvršuje prek treh vej oblasti, s katerimi mora vplivati na zavedanje državljanov, da kršenje zakonodaje oziroma predpisov škodi družbi kot celoti (Pavčnik 2015, 73-87).

Literatura navaja, da bi morala država s svojo vlogo in z infrastrukturo, ki jo upravlja, izvajati predvsem naslednje ukrepe (Tan 2002; Siegfried 2004; Albanese 2011):

- izobraževati državljane - v sistem javnega izobraževanja bi morali vključititi vsebine o posledicah kršenja avtorskih pravic (tudi na področju računalniškega piratstva);

- izvajati in podpirati protipiratske kampanje $\mathrm{v}$ okviru javne televizije in drugih medijev ter državljane ozaveščati glede zaščite avtorskih del z upoštevanjem avtorskega prava;

- dosledno sprejemati zakonodajo za zaščito in preprečevanje kršenja avtorskih pravic, ki se hitreje prilagaja smernicam piratstva programske opreme;

- dosledneje preganjati kršitve avtorskih pravic na vseh področjih in sankcionirati osebe, ki kršijo avtorske pravice;

- hitreje izvajati sodne postopke z objavo sankcij ob kršenju avtorskih pravic. 
Nekatere razvite države so kot odgovor na povečane stopnje spletnega piratstva sprejele restriktivno zakonodajo glede kršenja avtorskih pravic. Tako so na strani ponudbe piratskih vsebin uvedle pregon in zaprtje spletnih strežnikov, ki so gostili ali omogočali dostop do nezakonitih vsebin. Na strani povpraševanja po piratskih vsebinah pa so nekatere države sprejele interventne ukrepe, s katerimi skušajo zmanjšati stopnjo prenosov piratskih vsebin in njihovo deljenje med uporabniki (Arnold idr. 2014).

Med državnimi ukrepi je najbolj poznan ukrep iz leta 2009, ko so v Franciji uvedli sistem tristopenjskega zaznavanja kršenja avtorskih pravic s prenosi nezakonitih vsebin prek omrežij P 2 P. Za izvedbo tristopenjskega nadzora so sprejeli t.i. zakon H A D O P I (Haute Autorité pour la diffusion des œuvres et la protection des droits d'auteur sur internet). ${ }^{73}$ Tristopenjska opozorila se dejansko izvajajo tako, da se ob zaznavi kršenja avtorskih pravic domnevnemu kršilcu pošlje opozorilo o kršitvi. Ob prvi ponovitvi kršitve v naslednjih šestih mesecih pristojni organ ponovno pošlje opozorilo in če se v enem letu od drugega opozorila pri kršilcu ponovno zazna kršitev, se lahko poda predlog za kazenski pregon. Zakon H A D O P I iz leta 2009 je določal, da je bil prenašalcu nezakonitih vsebin v izreku sankcije po tretjem opozorilu tudi onemogočen dostop do svetovnega spleta. S sodbo francoskega ustavnega sodišča je bilo to določilo razveljavljeno, saj je sodišče razsodilo, da je dostop do svetovnega spleta temeljna človekova pravica (Lucchi 2011).

Podoben sistem poznajo tudi v ZDA, in sicer gre za Copyright Alert System (CAS), ki prek ponudnikov dostopa do spletnih storitev (IS P) uporabnike opozarjajo o njihovem nezakonitem početju. ${ }^{74}$ Pri kršitvi, ki so jo zaznali, potem ko so uporabnika že opozorili, Is P sprejmejo ukrepe, kot sta:

- zmanjšanje hitrosti dostopa do interneta;

- preusmeritev uporabnika ob zagonu brskalnika na spletno stran $\mathrm{z}$ izobraževalno vsebino glede kršenja avtorskih pravic in $\mathrm{z}$ obveznim reševanjem preskusa znanja.

Arnold idr. (2014) so preučevali učinkovitost sistema HADOPI in ugotovil, da se skupna stopnja piratstva zaradi zakonske uvedbe opo-

${ }^{73}$ Glej http://www.hadopi.fr/en/new-freedoms-new-responsibilities/graduated -response

${ }^{74}$ Glej http://www.copyrightinformation.org/resources-faq/copyright-alert-system -faqs/. 
zoril ni zmanjšala, izrazito pa se je spremenil način pridobitve piratskih vsebin. Ugotovili so, da je način prenosa nezakonitih digitalnih vsebin prešel iz P 2 P oziroma pri sistemu HAD O P I nadzorovanega sistema deljenja digitalnih vsebin $\mathrm{v}$ nenadzorovani sistem deljenja digitalnih vsebin. Najpogosteje so posamezniki prešli na pridobitev vsebin $\mathrm{v}$ sistemu odjemalec - strežnik ali v sistemu neposrednega prenosa med uporabniki. Arnold idr. (2014) pri tem dodajajo, da se bo stopnja piratstva najverjetneje zmanjšala, ko bodo ukrepi zoper strežnike, ki ponujajo nezakonite vsebine, učinkovitejši, saj se bo v tem primeru zmanjšala ponudba piratskih vsebin.

Ugotavljanje vpliva strožje zakonodaje na področju piratstva programske opreme na zmanjšanje stopnje uporabe piratske programske opreme je vključeno tudi v našo raziskavo.

\section{Uporaba odprtokodne programske opreme}

Odprtokodna programska oprema (OPO) je končnim uporabnikom navadno dostopna brezplačno in predstavlja oprijemljivo alternativo komercialni programski opremi. O P O konkurira komercialni programski opremi na več področjih, pri čemer Gramstad (2014, 2) izpostavlja, da O P O prevladuje na trgu programske opreme za spletne strežnike in operacijske sisteme mobilnih naprav. Ob tem pa dodaja, da je na področju namiznih računalnikov stanje nasprotno, saj večina uporabnikov še vedno uporablja komercialne pisarniške programe in operacijski sistem družbe Microsoft. Gramstad (2014) takšno stanje pripisuje dejstvu, da stopnja nameščenosti in uporabe O P O še ni dosegla kritične mase uporabnikov.

OPO kot neposredni brezplačni konkurent komercialne programske opreme vpliva na oblikovanje cen komercialne programske opreme in posledično prihodke korporacij, ki jo razvijajo; Raghu, Machado in Shina 2014 ugotavljajo, da se potencialni kupci komercialne programske opreme, ki se ne odločijo za njen nakup, odločajo med uporabo piratske programske opreme ali O PO. Ugotavljajo še, da je za korporacije $\mathrm{v}$ tem primeru ugodneje, da uporabljajo piratsko programsko opremo. Prav zaradi tega razloga naj bi tudi korporacija Microsoft spremenila svoj odnos do piratstva programske opreme, saj s piratstvom ohranja visoko stopnjo nameščenosti svoje programske opreme, kar vpliva na višjo stopnjo povpraševanja po zakoniti različici programov (Raghu, Machado in Shina 2014).

Na podlagi navedenega lahko sklepamo, da je glavni konkurent širje- 
nju O P O prav piratska programska oprema, ki je uporabnikom na voljo brezplačno in $\mathrm{v}$ dejansko izvirni kakovosti. Iz predhodno navedenih študij smo ugotovili tudi, da pri uporabnikih piratske programske opreme ne obstajajo moralni zadržki za njeno uporabo.

Prav zaradi navedenih razlogov želimo v nadaljevanju podrobneje predstaviti O P O kot alternativo komercialni programski opremi ter preučiti njene značilnosti in uporabnost. 


\section{Brezplačna in odprtokodna programska oprema}

Združenje F S F (Free Software Foundation) opredeljuje štiri pogoje, ki jih mora programska oprema izpolnjevati, da jo lahko opredelimo kot odprtokodno programsko opremo (O P O) (Open Source Software):

- vsak uporabnik ima pravico poganjati program ne glede na namen uporabe programa;

- uporabnik ima pravico, da dostopa do izvorne kode programa in da preuči delovanje programa, pri čemer ga lahko tudi spreminja za lastno uporabo;

- uporabnik ima pravico do javne objave spremenjenega oziroma izboljšanega programa;

- vsak uporabnik ima pravico do kopiranja in razširjanja programa.

ISlovar (2016) brezplačno programsko opremo (B P O) (angl. freeware) opredeljuje kot programsko opremo, za uporabo katere nosilcu materialne avtorske pravice ni treba plačati nadomestila za uporabo, postavlja pa druge omejitve, kot je prepoved spreminjanja ali razširjanja programa. B PO ne smemo enačiti z O P O, ki jo ISlovar (2016) opredeli kot "programska oprema, pri kateri licenčna pogodba daje uporabniku pravico uporabe, razširjanja in spreminjanja«.

Rey (2008) ugotavlja, da večina uporabnikov programske opreme ne uspe razlikovati med O Р О in В Р O. Bistveni pogoj О Р O je prav dostop do izvorne kode programa, medtem ko v večini primerov в P O tega ne omogoča. Pri B PO gre večinoma za programsko opremo $z$ omejeno licenco, izdano $\mathrm{z}$ namenom, da bi uporabniki začutili njeno uporabno vrednost in jo nato kupili z razširjenimi funkcionalnostmi ali po preteku brezplačnega preizkusnega obdobja. Dejansko ju povezuje predvsem to, da gre v večini primerov za programsko opremo, namenjeno širšemu krogu uporabnikov, ki je dostopna brezplačno (Rey 2008).

Razlikovanje med O P O in B P O opredeljuje tudi GN U, ${ }^{1}$ in sicer se raz-

${ }^{1}$ Glej https://www.gnu.org/philosophy/categories.sl.html. 
lika nahaja v razvoju izvorne oziroma programske kode. V primeru O P O je izvorna koda odprta, kar pomeni, da si lahko vsak razvijalec ali uporabnik prenese programsko kodo in jo modificira, dopolnjuje, nadgrajuje ter tako skuša izboljšati uporabnost računalniškega programa. Pri B P O pa je navadno dostop do programske kode onemogočen, pri čemer reprodukcija in distribucija te programske opreme ostajata brezplačni.

\subsection{Licence}

Licenca predstavlja sporazum med uporabnikom programske opreme in njenim izdajateljem oziroma avtorjem. ${ }^{2}$ Licenčni pogoji v osnovi določajo način uporabe programske opreme, pravico do kopiranja, distribuiranja in predelavo programske opreme.

OPO mora vsakomur omogočati, da jo prosto uporablja ali razširja, in sicer ne glede na to, ali to počne proti plačilu ali ne. Večina OP o je izdana pod pogoji licence GNU GPL - po načelu "copyleft «. ${ }^{3}$

GNU opredeljuje vrste programske opreme glede na licenčna določila, ki opredeljujejo pogoje za distribucijo, reprodukcijo in spreminjanje programske kode. Kategorije programske opreme so opredeljene kot: ${ }^{4}$

- OP O - omogoča dostop do programske kode, v nekaterih primerih pa lahko licence omejujejo prosto distribuiranje;

- programi v javni lasti - programi, ki niso pravno zaščiteni in je izvorna koda v javni lasti;

- programi, izdani pod načelom »copyleft« - pri njih so z licenco dovoljeni reprodukcija, distribucija, raba, razširjanje in spreminjanje programske opreme;

- lastniški programi - pri njih sta z licenco prepovedana razširjanje in spreminjanje tovrstne programske opreme;

- komercialni programi - v večini primerov jih razvijajo in distribuirajo gospodarske družbe s ciljem ustvarjanja finančnih prihodkov, pri čemer je večina komercialnih programov tudi lastniška;

\footnotetext{
${ }^{2}$ Glej https://opensource.org/licenses.

${ }^{3}$ Programska oprema, izdana po načelu »copyleft«, je podvržena licenci G NU GP L. Načelo "copyleft « določa pogoje razširjanja in izdajanja programske opreme (Bizjak 2012, 9). ISlovar (2016) »copyleft« opredeljuje kot "politik[o] licenciranja, ki podeljuje vsakemu uporabniku pravico do rabe, razširjanja in spreminjanja računalniških programov, dokumentov«.

${ }^{4}$ Glej https://www.gnu.org/philosophy/categories.sl.html.
} 


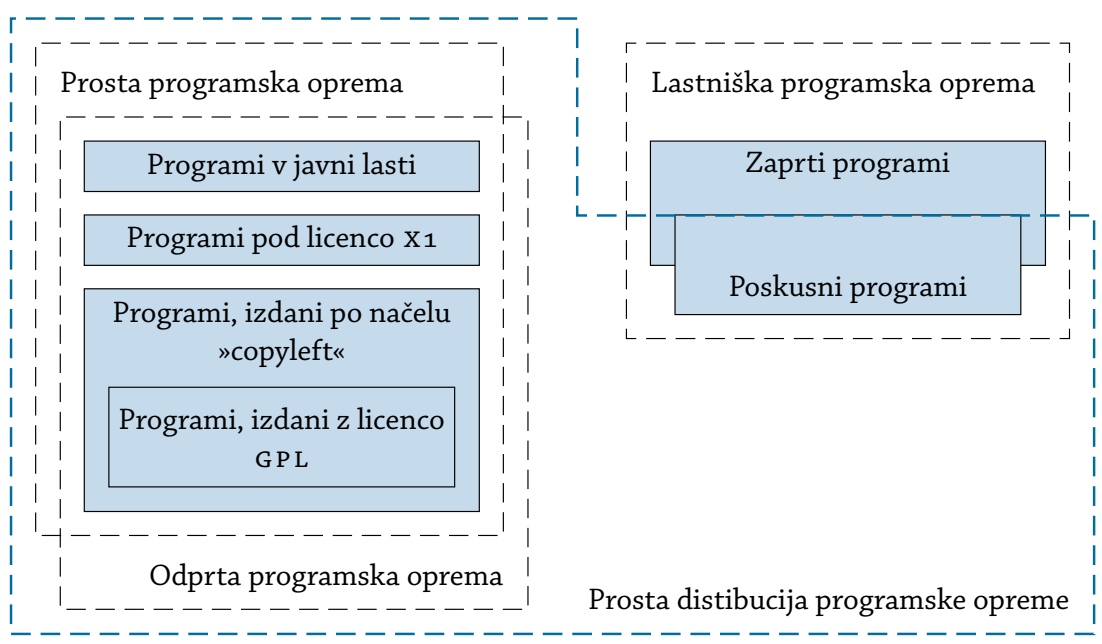

Slika 3.1 Kategorije programske opreme po merilih GNU (povzeto po https://www.gnu.org/philosophy/categories.sl.html)

- brezplačni programi (angl. freeware) - z licenco je dovoljeno distribuiranje, ne pa spreminjanje programske kode;

- polprosti programi (angl. semi-free software) - v neprofitne namene je takšne programe dovoljeno uporabljati, kopirati, razširjati in spreminjati;

- poskusni programi (angl. shareware) - dovoljeni sta distribucija proizvodov in uporaba za časovno obdobje, omejena $z$ licenčnimi pogoji, za neomejeno uporabo pa je treba plačati licenčnino.

Shematsko so vse kategorije programske opreme po merilih G N U prikazane na sliki 3.1.

Opredelitev odprte kode obsega deset meril, ki jih mora programska oprema izpolnjevati za izdajo odprtokodne licence o S I. ${ }^{5}$ Merila, ki jih določa organizacija O S I (Open Source Initiative), so naslednja:

- prodaja ali oddaja programske opreme ne sme biti omejena;

- izvorna koda mora biti javno dostopna in na voljo za brezplačen prenos, pri čemer mora omogočati spreminjanje programa;

- licenca mora omogočati, da se izpeljana dela iz izvorne kode distribuirajo pod enakimi pogoji kot izvorna;

- distribucija spremenjene izvorne kode je lahko z licenco omejena,

${ }^{5}$ Glej https://opensource.org/osd. 
če ta omogoča distribucijo popravkov izvorne kode med njeno gradnjo;

- prepovedana je vsakršna diskriminacija zoper osebo ali skupino oseb;

- prepovedano je vsakršno omejevanje uporabe programske opreme na katerem koli delovnem področju;

- pravice, ki izhajajo iz programske opreme, veljajo za vse imetnike programske opreme;

- licenca ne sme pripadati distribuciji programa, ampak mora biti prav taka, kot je bila dodeljena izvirnemu programu;

- licenca ne sme posegati ali omejevati druge programske opreme;

- zagotovljena mora biti tehnološka nevtralnost licence.

Programi, ki jih poznamo kot odprtokodne, pridobijo status O P O šele po izdaji z ustrezno licenco o S I. ${ }^{6}$ Združenje o S I preverja izdane licence O P O in jim odobri status odprtokodne licence, če izpolnjujejo pogoje iz definicije odprte kode.

\subsection{Značilnosti o P O}

Kot ugotavlja Bizjak (2012, 22), ima vsaka programska oprema več značilnosti, katerih pomembnost je odvisna od vrste in namena, ki ga ima programska oprema. Ob tem našteva bistvene značilnosti OPO, ki so:

- zanesljivost O P O, pri čemer to lastnost opredeljuje kot delovanje skladno s pričakovanji uporabnika in jo lahko enačimo s pojmom kakovosti OPO;

- skalabilnost O P O, ki je opredeljena kot zmožnost prilagajanja programske opreme okolju, v katerem deluje, njenemu načinu uporabe, načinu nameščanja in zmožnosti povečanja izkoriščenosti programske opreme;

- združljivost O P O (angl. compatibility) z drugo programsko opremo, ki je opredeljena kot zmožnost povezovanja dveh različnih programskih oprem med seboj, njuni zmožnosti izmenjave podatkov in sobivanja v istem računalniku;

- zmogljivost OPO, ki predstavlja hitrost izvajanja strojnih ukazov ali prenosa podatkov, kar merimo s posebnimi programi za merjenje zmogljivosti ali hitrosti prenosa podatkov;

${ }^{6}$ Glej https://opensource.org/licenses. 
- varnost OPO, ki je opredeljena kot preprečitev tveganja neposrednih vdorov $\mathrm{v}$ informacijski sistem ali vdorov $\mathrm{z}$ namestitvijo zlonamerne oziroma škodljive programske opreme (angl. malware). ${ }^{7}$

\subsection{Prednosti in slabosti O P O}

Prednosti in slabosti OPO so opredeljene na podlagi primerjave s komercialno programsko opremo. Bizjak $(2012,28)$ navaja, da mora programska oprema zaradi zahtev uporabnikov z vsako posodobitvijo postati boljša, kar pomeni funkcionalnejša in prijaznejša do uporabnika. Morgan in Finnegan (2007) sta med uporabniki o P O izvedla raziskavo in na podlagi ugotovitev raziskave klasificirala prednosti in pomanjkljivosti O P O. Prednosti sta opredelila kot:

- prilagodljivost OPO - zaradi prostega poseganja v programsko kodo je program možno prilagoditi lastnim potrebam;

- varnost O P O - zaradi prostega vpogleda v programsko kodo lahko sproti odpravljamo varnostno ranljivost;

- kakovost O P - v smislu zanesljivosti delovanja;

- zmogljivost OР O - v smislu hitrosti izvajanja operacij;

- združljivost OPO - je omogočena s podpiro velikega števila datotečnih formatov;

- razvoj OPO - hitrejša odprava napak in velika baza znanja za izboljšave;

- nizki stroški pridobitve OPO - zaradi nižjih ali ničelnih stroškov licenčnine;

- neodvisnost od proizvajalca programske opreme - zaradi nezavezujočih licenčnih pogojev lažje prehajamo od enega do drugega ponudnika OPO;

- spodbujanje inovativnosti - odprtokodna zasnova programske opreme omogoča inovativnost v smislu neprestanega razvoja programske opreme.

Slabosti O P O sta Morgan in Finnegan (2007) opredelila kot:

- združljivost - nepopolna združljivost, predvsem z datotečnimi standardi komercialne programske opreme;

\footnotetext{
${ }^{7}$ ISlovar (2016) škodljivo oziroma zlonamerno programsko opremo (angl. malicious software ali malware) definira kot programe, katerih namen je, da škodljivo vplivajo na delovanje informacijskega sistema. Kot primere zlonamerne programske opreme ISlovar navaja viruse, črve, stranska vrata, trojanske konje in vohunske programe.
} 
- dokumentacija - redko dostopna, večinoma zastarela, večkrat opuščena v fazi razvoja O P O;

- pomanjkanje strokovnega znanja uporabnikov - pri povprečno ozaveščenem računalniškemu uporabniku OPO zaradi slabšega poznavanja tovrstne programske opreme privede do najemanja dražje strokovno usposobljene delovne sile za gospodarske družbe;

- množenje različic - različne izdaje programske opreme povzročajo zmedo pri odločitvi, katero izbrati;

- pomanjkanje funkcionalnosti - razpoložljivost funkcionalnosti večkrat zaostaja za komercialno programsko opremo;

- pomanjkanje podpore - za OPO večkrat ni organizirane tehnične podpore, ki je organizirana v obliki spletnih forumov in blogov;

- lastništvo - neznan nosilec odgovornosti ob morebitnih težavah;

- stroški izobraževanj - višji stroški izobraževanj kot pri komercialni programski opremi.

\subsection{O P O kot alternativa komercialni programski opremi}

Uporaba OPO se v svetu iz leta v leto povečuje (Hars in Ou 2002, 1). Zaradi vse večje uporabe OРО so se tudi nekateri veliki proizvajalci programske opreme že v devetdesetih letih preteklega stoletja odločili podpreti odprtokodne projekte. Projekti O P O so postali zelo uspešni in nadomeščajo komercialno programsko opremo. Med bolj poznanimi projekti O P O, ki jih predstavljamo v nadaljevanju, so operacijski sistem Linux, ${ }^{8}$ pisarniški paket LibreOffice ${ }^{9}$ in internetni brskalnik Mozilla Firefox. $^{10}$

\section{Linux}

Linux je jedro odprtokodnih operacijskih sistemov, ki jih poznamo $\mathrm{v}$ različnih distribucijah. ${ }^{11}$ Najbolj poznane distribucije Linuxa so Debian GNU/Linux, Ubuntu, open SUSE, Fedora, Mandriva Linux in Linux Mint. ${ }^{12}$ Operacijski sistem Linux je leta 1991 ustvaril takrat še dodiplomski študent Linus Torvalds (Lerner in Tirole 2002, 208). Linux je izdan pod pogojem G N U G P L licence (Fogel 2015, 193).

${ }^{8}$ Glej https://www.linux.org/.

${ }^{9}$ Glej https://www.libreoffice.org/.

${ }^{10}$ Glej https://www.mozilla.org/en-GB/firefox/new/.

${ }^{11}$ Glej https://www.gnu.org/gnu/linux-and-gnu.sl.html.

${ }^{12}$ Glej http://www.linux.com/directory/Distributions/popular-distributions. 
Bizjak $(2012,44)$ navaja, da so prednosti operacijskega sistema Linux predvsem njegova zanesljivost, cena, varnost, prilagodljivost strojni opremi in licenčna politika. Kljub prednostim je Linuxov tržni delež med operacijskimi sistemi še vedno zanemarljiv in znaša $2,4 \% .{ }^{13}$

\section{Mozilla Firefox}

Mozilla Firefox je odprtokodni spletni brskalnik, ki je bil v polni različici izdan leta 2004 in je preveden v več kot 70 jezikov. ${ }^{14}$ Brskalnik je bil razvit na podlagi programske kode Netscape communicatorja. ${ }^{15}$ Njegov razvoj poteka $v$ šesttedenskih ciklih od prve poskusne različice do končne različice za izdajo ${ }^{16}$ (Khomh idr. 2012). Največja prednost brskalnika je njegova prilagodljivost, saj se razširitve in dodatki, ki povečujejo uporabniško vrednost brskalnika, razvijajo $v$ ločenih projektih (prav tam). Tržni delež Mozille Firefox v svetu je bil junija 2017 12,0\%; pred njim sta bila uvrščena brskalnika Google Chrome s 59,5-odstotnim deležem in Microsoft Internet Explorer s 16,8-odstotnim deležem. ${ }^{17}$

\section{LibreOffice}

LibreOffice je odprtokodni pisarniški paket, ki v osnovi vsebuje urejevalnik besedil, program za delo s preglednicami, program za pripravo predstavitev, program za risanje diagramov in grafikonov ter druge programe in pripomočke ${ }^{18}$ Pisarniški paket LibreOffice razvija neprofitno združenje The Document Foundation, ki je bilo ustanovljeno po tem, ko so nekateri razvijalci zapustili projekt OpenOffice.org (Bizjak 2012, 47). Konec leta 2014 je pisarniški paket LibreOffice v svetu uporabljalo najmanj 80 milijonov uporabnikov (Libreoffice 2014).

Kakovost O P O se v nekaterih primerih lahko primerja s komercialno programsko opremo, v nekaterih primerih pa jo celo presega (Pankaja in Raj 2013). Pankaja in Raj (2013) sta na podlagi devetih lastnosti pro-

${ }^{13}$ Glej https://www.netmarketshare.com/.

${ }^{14}$ Glej https://www.mozilla.org/sl/about/history/.

${ }^{15}$ Netscape communicator je bil zelo razširjen internetni brskalnik v uporabi v 9o. letih dvajsetega stoletja.

${ }^{16}$ Skupno trajanje razvoja različice brskalnika je 24 tednov. V tem času je zajeto 6 tednov razvoja v predrazličici, 6 tednov $\mathrm{v}$ alfa različici, 6 tednov $\mathrm{v}$ beta različici in 6 tednov $\mathrm{v}$ različici za izdajo (Khomh idr. 2012, 2).

${ }^{17}$ Glej https://www.netmarketshare.com/.

${ }^{18}$ Urejevalnik enačb, program za delo z bazami podatkov; glej https://sl.libreoffice.org/o -izdelku/zakaj-libreoffice/. 
Preglednica 3.1 Primerjava komercialne programske opreme in OPO

\begin{tabular}{|c|c|c|}
\hline Lastnost & Komercialna PO & OPO \\
\hline $\begin{array}{l}\text { Stroški } \\
\text { nakupa }\end{array}$ & $\begin{array}{l}\text { Visoki stroški nakupa PO, integra- } \\
\text { cije, časovna omejitev licence. }\end{array}$ & $\begin{array}{l}\text { Nizki ali ničelni stroški aktivacije, } \\
\text { ni časovnih omejitev licence. }\end{array}$ \\
\hline $\begin{array}{l}\text { Storitve in } \\
\text { podpora }\end{array}$ & $\begin{array}{l}\text { Visoka stopnja nudenja storitev } \\
\text { in podpore izdelku. }\end{array}$ & $\begin{array}{l}\text { Ni organiziranih storitev ali pod- } \\
\text { pore. Podpora je večinoma v } \\
\text { obliki spletnih skupnosti ali blo- } \\
\text { gov. }\end{array}$ \\
\hline $\begin{array}{l}\text { Inovativ- } \\
\text { nost }\end{array}$ & $\begin{array}{l}\text { Inovativnost programa v obliki } \\
\text { nadgradenj oziroma novih različic } \\
\text { programa. Inovativnost zasleduje } \\
\text { profitni motiv. }\end{array}$ & $\begin{array}{l}\text { Spodbuja inovativnost z možno- } \\
\text { stjo dodelave izvorne kode pro- } \\
\text { grama z možnostjo sodelovanja } \\
\text { vsakega posameznika na ravni no- } \\
\text { vih idej in programiranja. }\end{array}$ \\
\hline Varnost & $\begin{array}{l}\text { Zaznana kot manj varna pro- } \\
\text { gramska oprema. Sicer zaradi ra- } \\
\text { zvoja v zaprtem okolju večji nad- } \\
\text { zor nad programsko kodo. }\end{array}$ & $\begin{array}{l}\text { Zaznana kot varnejša programska } \\
\text { oprema, z vzpostavitvijo organi- } \\
\text { zacij za pregled kode se povečuje } \\
\text { varnost za uporabnika. }\end{array}$ \\
\hline Uporabnost & $\begin{array}{l}\text { Preverjena, testirana, namenjena } \\
\text { specifični uporabi, priložena na- } \\
\text { vodila za uporabo in omogočeno } \\
\text { izobraževanje uporabnikov. }\end{array}$ & $\begin{array}{l}\text { Uporabnost O P O se izboljšuje s } \\
\text { testiranjem in z izdajo navodil za } \\
\text { uporabo. }\end{array}$ \\
\hline Standardi & $\begin{array}{l}\text { Uporaba lastnih standardov in } \\
\text { formatov. Formati niso dani na } \\
\text { voljo industriji za prilagoditev. }\end{array}$ & $\begin{array}{l}\text { Odprti, javno dostopni standardi. } \\
\text { Brez odprtih standardov bi bila } \\
\text { interakcija na internetu nemo- } \\
\text { goča. }\end{array}$ \\
\hline Dosegljivost & $\begin{array}{l}\text { Nakup v spletnih ali klasičnih tr- } \\
\text { govinah. Včasih omogočena upo- } \\
\text { raba testnih različic P O. }\end{array}$ & Prosto dosegljiva na internetu. \\
\hline $\begin{array}{l}\text { Transpa- } \\
\text { rentnost }\end{array}$ & $\begin{array}{l}\text { Ni pregleda nad delovanjem pro- } \\
\text { grama. Omogočena samo uporaba } \\
\text { dodeljenih funkcij. }\end{array}$ & $\begin{array}{l}\text { Popolna transparentnost z mo- } \\
\text { žnostjo vpogleda, gradnje, pri- } \\
\text { lagoditve in distribucije izvorne } \\
\text { kode }\end{array}$ \\
\hline Zanesljivost & $\begin{array}{l}\text { Dostopna samo testirana končna } \\
\text { različica Po, kar nudi visoko sto- } \\
\text { pnjo zanesljivosti delovanja. }\end{array}$ & $\begin{array}{l}\text { Zanesljivost slabša na račun šte- } \\
\text { vilnih nepreverjenih distribucij. }\end{array}$ \\
\hline
\end{tabular}

gramske opreme primerjala komercialno programsko opremo in O P O, kar prikazujemo v preglednici 3.1.

\subsection{Financiranje OP O}

Odprtokodna in prosta programska oprema sta v večini primerov ponujena $\mathrm{v}$ brezplačno uporabo končnemu uporabniku, ta pa mora tako 
programsko opremo uporabljati skladno z licenčnimi pogoji. Stroške, ki nastanejo $\mathrm{z}$ razvojem, vzdrževanjem, distribucijo, zagotavljanjem podpore in drugimi storitvami, povezanimi s tovrstno programsko opremo, morajo organizacije ali posamezniki pokriti z ustvarjanjem prihodkov. $V$ večini primerov ti ne nastanejo s klasičnim trženjem in prodajo O P O končnemu uporabniku, ampak jih ustvarjajo z upravljanjem drugih projektov, povezanih z OPO (Fogel 2015).

Fogel (2015) ugotavlja še, da pri razvoju odprtokodnih projektov sodeluje vedno manj prostovoljnih programerjev oziroma je njihov prispevek k oblikovanju celotne programske kode vedno manjši. To dejstvo utemeljuje $s$ tem, da odprtokodne rešitve uporablja vedno več gospodarskih družb, ki te rešitve prilagaja svojim potrebam, za kar odprtokodni projekti potrebujejo plačane programerje. Prav zato so gospodarske družbe pripravljene plačevati razvijalce O P O. Finančna vlaganja gospodarskih družb v razvoj O PO so povezana $\mathrm{z}$ naslednjimi razlogi (Fogel 2015):

- delitev bremena - pri tem različne gospodarske družbe ali organizacije izkoristijo skupne potrebe po programski opremi in financirajo razvoj O PO, ki ga pozneje privzamejo za delovanje v lastni organizaciji ob deljenih stroških za razvoj;

- podpora prodaji storitev - pri tem gospodarske družbe, ki prodajajo storitve, podpirajo razvijalce O P O, ki omogočajo delovanje njihovih storitev;

- podpora prodaji strojne opreme - pri tem je pomembno, da OP O podpira delovanje strojne opreme investitorja;

- trženje - gospodarske družbe financiranje projektov razvoja O P O večkrat izkoristijo v promocijske namene;

- sprememba licence v komercialno - gospodarske družbe financirajo razvoj O P O, ki jo pozneje prodajajo kot klasično komercialno programsko opremo. ${ }^{19}$

Financiranje izdelave in razvoja O PO se večkrat izvaja tudi prek donacij uporabnikov, in sicer fizičnih ali pravnih oseb (Fogel 2015, 80). Za primer povejmo, da je organizacija The Document Foundation, ki razvija pisarniški paket LibreOffice, v letu 2014 prejela približno 67.500 donacij v skupni vrednosti 595.000,00 E U R (Libreoffice 2014, 9).

\footnotetext{
${ }^{19}$ Fogel $(2015,84)$ pri tem kot najbolj znan primer omenja program My S QL.
} 



\section{Piratstvo programske opreme - raziskava}

\subsection{Potek raziskave in predstavitev vzorca}

Raziskavo o razširjenosti piratstva programske opreme smo opravili med študenti štirih držav, Slovenije, Srbije, Poljske in Velike Britanije. Pri oblikovanju stratificiranega vzorca smo upoštevali število študentov $\mathrm{v}$ posamezni državi ${ }^{1}$ ter število prebivalcev posamezne preučevane $\mathrm{dr}$ žave. ${ }^{2}$ Izračunali smo deleže študentske populacije v celotni populaciji posamezne preučevane države. ${ }^{3}$ Delež študentov v celotni populaciji države je predstavljal vzorec $\mathrm{z}$ razmerjem študentov: 22,4\% iz Velike Britanije, $29,7 \%$ iz Poljske, 19,0 \% iz Srbije in $28,9 \%$ iz Slovenije.

Anketiranje je potekalo prek spleta. Anketni vprašalnik (priloga 1) smo pripravili v spletni aplikaciji $1 \mathrm{KA}^{4}$ in ga $\mathrm{v}$ izpolnjevanje študentom posredovali prek objave na socialnih omrežjih fakultet in povezav, ki so jih zagotovili zaposleni na posameznih fakultetah. Vzorec izbora je namenski, saj so bili $k$ reševanju anketnega vprašalnika povabljeni izključno študentje. V Sloveniji je bil anketni vprašalnik izveden v slovenskem jeziku. Za izvedbo anketiranja v Srbiji smo vprašalnik prevedli v srbski jezik, v Veliki Britaniji in na Poljskem ${ }^{5}$ pa se je anketiranje izvajalo $\mathrm{v}$ angleškem jeziku. Spletni vmesnik $1 \mathrm{KA}$ smo za izvedbo anketiranja v

\footnotetext{
${ }^{1}$ Po podatkih Eurostata (glej http://ec.europa.eu/eurostat/tgm/table.do?tab=table\&init $=1$ \&language $=$ en\&pcode $=$ tpsooo62\&plugin=1) je bilo konec leta $2012 \mathrm{v}$ Veliki Britaniji 2.495.80o študentov, na Poljskem 2.007.200, v Sloveniji pa 104.000. Po statističnem letopisu Srbije (Statistical Office of the Republic of Serbia 2014) pa je bilo leta $2012 \mathrm{~V}$ Srbiji 238.945 študentov.

${ }^{2}$ Po podatkih Svetovne banke (glej Http://databank.worldbank.org/data/views/reports /tableview.aspx?isshared=true) je bilo v letu 2012 v Veliki Britaniji 63.700.300, na Poljskem 38.535.873, v Srbiji 7.199.077 in v Sloveniji 2.057.159 prebivalcev.

${ }^{3}$ Velika Britanija 3,9\%, Poljska 5,2 \%, Srbija 3,3\% in Slovenija 5,1\%.

${ }^{4}$ Glej https://www.1ka.si/.

${ }^{5}$ Anketni vprašalnik na Poljskem se je izvajal v angleškem jeziku zaradi omejenih finančnih sredstev, povezanih z raziskavo, poleg tega pa tudi zaradi našega nerazumevanja tega jezika in posledično lažjega interpretiranja ter pojasnjevanja posameznih vprašanj, če bi se ta pojavila.
} 
4 Piratstvo programske opreme - raziskava

Preglednica 4.1 Delež odgovorov glede na stopnjo študija po preučevanih državah

\begin{tabular}{llrr}
\hline Stopnja študija & Država & $(1)$ & $(2)$ \\
\hline Študijski programi 1. stopnje & Slovenija & 35 & 17,5 \\
& Srbija & 22 & 11,0 \\
& Poljska & 43 & 21,5 \\
& Velika Britanija & 26 & 13,0 \\
\hline Študijski programi 2. stopnje & Slovenija & 23 & 11,5 \\
& Srbija & 16 & 8,0 \\
& Poljska & 16 & 8,0 \\
& Velika Britanija & 19 & 9,5 \\
\hline Skupaj & & 200 & 100,0 \\
\hline
\end{tabular}

OP OMBE (1) število odgovorov, (2) delež odgovorov.

posamezni državi jezikovno nastavili na slovenski, poljski, angleški in na srbski jezik, kar je anketirancem še dodatno olajšalo izpolnjevanje in razumevanje anketnega vprašalnika. Anketiranje je bilo anonimno.

Anketni vprašalnik je vseboval 71 vprašanj zaprtega tipa. Na večino vprašanj je bilo mogoče podajati odgovore v obliki 5-stopenjske Likertove lestvice. Vprašalnik je bil razdeljen na štiri dele. V prvem delu so se vprašanja nanašala na veščine IKT-pismenosti anketirancev in na način pridobitve programske opreme. $V$ drugem delu so anketiranci odgovarjali na vprašanja, povezana $z$ uporabo piratske programske opreme, njeno nameščenostjo in dejavniki, ki bi znižali stopnjo uporabe piratske programske opreme. $V$ tretjem sklopu ankete smo anketirance spraševali po njihovi uporabi brezplačne ali odprtokodne programske opreme. Četrti sklop je vseboval tri splošna vprašanja.

Vzorec smo oblikovali glede na število prejetih popolno izpolnjenih vprašalnikov. Predvideli smo, da bomo iz vsake posamezne države prejeli do 100 popolno izpolnjenih vprašalnikov, vendar smo se glede na slabši odziv udeležencev odločili, da bo celoten vzorec obsegal 200 popolno izpolnjenih anketnih vprašalnikov. Iz Slovenije smo prejeli 94 popolno izpolnjenih vprašalnikov, iz Srbije 45, iz Poljske 64 in iz Velike Britanije 45.

Vzorec smo oblikovali v že omenjenem razmerju: $28,9 \%$ vključenih enot iz Slovenije, 19,0\% iz Srbije, 29,7\% iz Poljske in $22,4 \%$ iz Velike Britanije. Na podlagi izračunanih razmerij smo v vzorec vključili 58 popolno rešenih vprašalnikov slovenskih študentov, 38 srbskih, 59 poljskih in 45 britanskih, kar skupno predstavlja vzorec 200 enot. Popolno izpolnjeni vprašalniki so bili izbrani naključno. Izbira se je izvedla s po- 
Preglednica 4.2 Delež odgovorov glede na spol po preučevanih državah

\begin{tabular}{llrr}
\hline Spol & Država & $(1)$ & $(2)$ \\
\hline Moški & Slovenija & 33 & 16,5 \\
& Srbija & 20 & 10,0 \\
& Poljska & 32 & 16,0 \\
& Velika Britanija & 26 & 13,0 \\
\hline Ženski & Slovenija & 25 & 12,5 \\
& Srbija & 18 & 9,0 \\
& Poljska & 27 & 13,5 \\
& Velika Britanija & 19 & 9,5 \\
\hline Skupaj & & 200 & 100,0 \\
\hline
\end{tabular}

OP OM B E (1) število odgovorov, (2) delež odgovorov.

močjo generatorja naključnih števil. V okviru splošnih vprašanj smo vzorec želeli natančneje opredeliti glede stopnje študijskega programa anketirancev in njihovega spola.

V vzorcu je 63,0 \% študentov študijskih programov 1. stopnje in 37,0 \% študijskih programov 2. stopnje. Podrobnejši prikaz anketirancev, zajetih v vzorcu glede na študijski program in državo prebivanja populacije, je prikazan v preglednici 4.1.

V vzorcu je 55,5\% anketiranih študentov moškega spola in $44,5 \%$ anketiranih ženskega spola. Podrobnejši prikaz anketirancev, zajetih $\mathrm{v}$ vzorcu glede na spol in državo prebivanja, je prikazan v preglednici 4.2.

\subsection{Analiza anketnih vprašalnikov}

Podatke, ki smo jih zbrali s spletno anketo, smo izvozili v program za delo s preglednicami Microsoft Excel. Za zagotovitev ustreznega razmerja izpolnjenih anketnih vprašalnikov v vzorcu smo s pomočjo generatorja naključnih števil izločili odvečne anketne obrazce. Pridobljene podatke smo nato uvozili in obdelali s programom SPSS.

\section{Ocena I K T-pismenosti in način pridobitve programske opreme}

Anketiranci so podali samooceno I K T-pismenosti (preglednica 4.3), v katero so bila vključena vprašanja skladno z metodologijo Eurostat za ugotavljanje računalniških veščin. Svoje veščine so anketiranci ocenili s povprečno oceno $\mathrm{M}=3,5 .{ }^{6}$ Najvišjo oceno so anketiranci podali za splo-

\footnotetext{
${ }^{6}$ Anketiranci so lastno I K T-pismenost ocenjevali na lestvici od 1 do 5, pri čemer je ocena 5 pomenila, da so njihove računalniške veščine razvite, ocena $1 \mathrm{pa}$, da teh veščin nimajo.
} 
Preglednica 4.3 Ocena IKT-pismenosti anketirancev

\begin{tabular}{lcc}
\hline Spremenljivke & $(1)$ & $(2)$ \\
\hline Splošna opravila v okolju operacijskega sistema & 4,7 & 0,5 \\
Uporaba osnovnih matematičnih operacij v programih za delo & 4,1 & 0,9 \\
s preglednicami & & \\
Uporaba programov za stiskanje (kompresiranje) podatkov & 3,9 & 1,0 \\
Uporaba programov za pripravo predstavitev & 3,9 & 1,0 \\
Napredna opravila v okolju operacijskega sistema & 3,6 & 1,0 \\
Uporaba programov za zaščito računalnika pred virusi & 3,4 & 1,1 \\
Priklop računalnika v mrežo in upravljanje z mrežo & 2,7 & 1,1 \\
Programiranje v računalniškem programskem jeziku & 1,7 & 0,9 \\
\hline
\end{tabular}

OP ОМвE (1) povprečje, (2) standardni odklon.

šna opravila v okolju operacijskega sistema Windows, ki zajema veščine, kot so kopiranje, lepljenje, brisanje, ustvarjanje in poimenovanje datotek $(M=4,7)$. S povprečno oceno vsaj 4 so se anketiranci ocenili tudi pri uporabi osnovnih matematičnih operacij v programih za delo s preglednicami $(M=4,1)$. Kot najslabše razvite so anketiranci svoje veščine ocenili na področju upravljanja računalniške mreže $(M=2,7)$ in programiranja v programskem jeziku $(M=1,7)$. Povprečne ocene drugih veščin so razvidne iz preglednice $4 \cdot 3$.

Iz navedenega sklepamo, da je večina anketirancev dobro računalniško pismena, kar izhaja že iz dejstva, da gre za študentsko populacijo, ki pri svojih vsakdanjih opravilih uporablja računalnik.

Anketirance smo vprašali, na kakšen način pridobivajo programsko opremo $^{7}$ (preglednica 4.4). Iz prejetih odgovorov smo ugotovili, da programsko opremo najpogosteje pridobijo $\mathrm{z}$ nakupom računalnika $\mathrm{z}$ že nameščeno licenčno programsko opremo $(M=3,3)$. Najverjetneje je to posledica tržnih aktivnosti prodajalcev računalniške opreme, saj se večina novih računalnikov prodaja $\mathrm{z}$ nameščenim operacijskim sistemom in drugo uporabniško programsko opremo. Glede pridobivanja programske opreme s pomočjo internetnega omrežja je najvišjo povprečno oceno dosegel način prenosa programske opreme $s$ pomočjo omrežij P 2 P $(M=2,8)$. Najnižje so anketiranci označili možnost, da so piratsko programsko opremo dobili nameščeno že ob nakupu računalnika $(\mathrm{M}=$

\footnotetext{
${ }^{7}$ Anketiranci so pogostost posameznega načina pridobitve programske opreme ocenjevali na petstopenjski lestvici z ocenami vedno, pogosto, včasih, redko in nikoli. Odgovore smo za potrebe analize številsko ovrednotili, in sicer smo odgovoru »vedno" dodelili oceno (5), pogosto (4), včasih (3), redko (2) in nikoli (1).
} 
Preglednica 4.4 Način pridobitve programske opreme

\begin{tabular}{llc}
\hline Spremenljivke & (1) & $(2)$ \\
\hline Kupil sem računalnik z že nameščeno licenčno programsko opremo. & 3,3 & 1,3 \\
Prenesel sem jo s pomočjo programov za izmenjavo datotek P 2 P. & 2,8 & 1,3 \\
Prenesel sem jo nepos. z interneta s splet. strani s piratsko vsebino. & 2,5 & 1,2 \\
Zakonito sem jo kupil in prenesel z interneta. & 2,4 & 1,2 \\
Kupil sem jo v trgovini z računalniško opremo. & 2,4 & 1,3 \\
Programsko opremo sem namestil na več računalnikov, kot to & 1,9 & 1,1 \\
dovoljuje licenca. & 1,7 & 0,9 \\
Kupil sem medij (CD, DVD) s piratsko programsko opremo. & 1,4 & 0,8 \\
Kupil sem že računalnik z že nameščeno piratsko prog. opremo. & &
\end{tabular}

OP ОМвE (1) povprečje, (2) standardni odklon.

Preglednica 4.5 Korelacijska analiza načina pridobitve programske opreme

\begin{tabular}{|c|c|c|c|c|c|c|c|}
\hline Spremenljivke & 1. & 2. & 3. & 4. & 5. & 6. & 7. \\
\hline $\begin{array}{l}\text { 1. Zakonito kupil } \\
\text { v trgovini. }\end{array}$ & & & & & & & \\
\hline $\begin{array}{l}\text { 2. Zakonito prenesel } \\
\mathrm{z} \text { interneta. }\end{array}$ & $0,31^{* *}$ & & & & & & \\
\hline $\begin{array}{l}\text { 3. Kupil računalnik } \\
\text { z licenčno P O. }\end{array}$ & $0,37^{* *}$ & & & & & & \\
\hline $\begin{array}{l}\text { 4. Prenesel s programi } \\
\text { P } 2 \text { P. }\end{array}$ & $-0,42^{* *}$ & & $-0,35^{* *}$ & & & & \\
\hline $\begin{array}{l}\text { 5. Prenesel s piratskih } \\
\text { spletnih strani. }\end{array}$ & $-0,27^{* *}$ & $-0,15^{* *}$ & $-0,39^{* *}$ & $0,50^{* *}$ & & & \\
\hline $\begin{array}{l}\text { 6. Kupil računalnik } \\
\text { s piratsko PO. }\end{array}$ & & & & $0,17^{*}$ & $0,22^{* *}$ & & \\
\hline $\begin{array}{l}\text { 7. Kupil (CD, DVD) } \\
\text { s piratsko PO. }\end{array}$ & & & $-0,18^{*}$ & & $0,28^{* *}$ & $0,18^{* *}$ & \\
\hline $\begin{array}{l}\text { 8. Komercialno namestil } \\
\text { na več računalnikov. }\end{array}$ & & $0,34^{*}$ & & $0,20^{* *}$ & & $0,18^{*}$ & \\
\hline
\end{tabular}

OРОМ Ве ${ }^{* *}$ Statistično značilna korelacija pri $p=0,01 .{ }^{*}$ Statistično značilna korelacija pri $p=0,05$.

1,4). Pri tem pa moramo upoštevati tudi možnost, da se kupci računalnikov lahko tudi ne zavedajo vrste programske opreme, ki je nameščena na računalniku ob njegovem nakupu. Povprečne ocene drugih načinov pridobivanja programske opreme so razvidne v preglednici 4.4.

V nadaljevanju nas je zanimalo, ali obstajajo statistično značilne povezave med posameznimi spremenljivkami. Zato smo izvedli korelacijsko analizo (preglednica 4.5). 
Med spremenljivkami (1)»Programsko opremo sem zakonito kupil v trgovini z računalniško opremo in (4) »Programsko opremo sem prenesel s pomočjo programov $\mathrm{P} 2 \mathrm{P}$ « $(-0,42)$ ter $(5)$ »Prenesel sem jo z interneta s spletnih strani s piratsko vsebino« $(-0,27)$ obstaja negativna povezava, kar pomeni, da posamezniki, ki kupujejo programsko opremo, te ne prenašajo na nezakoniti način. Ugotovili smo, da obstajajo negativne srednje močne povezave tudi med spremenljivkami (3) »Kupil sem računalnik z že nameščeno licenčno programsko opremo《 in (4) »Programsko opremo sem prenesel s pomočjo programov P 2 P « $(-0,35)$ ter (5) "Prenesel sem jo $z$ interneta s spletnih strani s piratsko vsebino" $(-0,39)$, iz česar lahko sklepamo, da se z nakupom računalnika z že nameščeno komercialno programsko opremo zmanjšajo potrebe posameznika po pridobivanju piratskih programov.

Najmočnejšo pozitivno statistično značilno povezavo smo zaznali med spremenljivkama (4) »Programsko opremo sem prenesel s pomočjo programov P $2 \mathrm{P}$ « in (5) »Prenesel sem jo $z$ interneta s spletnih strani s piratsko vsebino « $(0,50)$. Iz tega lahko sklepamo, da $\mathrm{z}$ rastjo prenosov piratske programske opreme s pomočjo omrežij P 2 P naraščajo tudi prenosi z internetnih strani s piratskimi vsebinami.

Srednje močna pozitivna povezava obstaja tudi med spremenljivkama (2) "Programsko opremo sem kupil in prenesel z interneta« in (8) »Programsko opremo sem namestil na več računalnikov, kot to dovoljuje licenca«. Iz tega lahko sklepamo, da z večanjem števila zakonitih nakupov programske opreme na internetu narašča nepooblaščeno nameščanje programske opreme na več računalnikov, kot to dovoljuje licenca, kar je opredeljeno kot piratstvo programske opreme. Vse povezave so statistično značilne $(p<0,005)$.

Anketirance smo vprašali tudi, kdo jim je piratsko programsko opremo namestil na računalnik. Nekaj manj kot polovica (40\%) si je piratsko programsko opremo namestila sama, $37 \%$ anketirancem pa prijatelj, znanec ali sorodnik. Anketiranci so v $13 \%$ primerih izbrali »računalniški strokovnjak«, 9 \% anketiranih je izbralo možnost »drugo «, medtem ko je $1 \%$ izbral odgovor »trgovec«.

\section{Stopnja nameščenosti in uporabe piratske programske opreme}

Zanimalo nas je, katero piratsko programsko opremo imajo anketiranci nameščeno na svojih računalnikih. Prejete odgovore smo predstavili v preglednici 4.6. Največji delež nameščene piratske programske opreme pripada pisarniškim paketom, in sicer ta znaša $64,5 \%$. Najnižja stop- 
Preglednica 4.6 Nameščenost programske opreme

\begin{tabular}{|c|c|c|c|}
\hline Spremenljivke & (1) & (2) & (3) \\
\hline \multirow[t]{3}{*}{ Operacijski sistem } & $\mathrm{Da}$ & 89 & 44,5 \\
\hline & $\mathrm{Ne}$ & 101 & 50,5 \\
\hline & Ne vem & 10 & 5,0 \\
\hline \multirow[t]{3}{*}{ Pisarniški paket } & $\mathrm{Da}$ & 129 & 64,5 \\
\hline & $\mathrm{Ne}$ & 60 & 30,0 \\
\hline & Ne vem & 11 & 5,5 \\
\hline \multirow[t]{3}{*}{ Protivirusni program } & $\mathrm{Da}$ & 83 & 41,5 \\
\hline & $\mathrm{Ne}$ & 101 & 50,5 \\
\hline & Ne vem & 16 & 8,0 \\
\hline \multirow[t]{3}{*}{ Programi za obdelovanje fotografij } & $\mathrm{Da}$ & 96 & 48,5 \\
\hline & $\mathrm{Ne}$ & 95 & 47,5 \\
\hline & Ne vem & 9 & 4,5 \\
\hline \multirow[t]{3}{*}{ Programi za CAD-oblikovanje } & $\mathrm{Da}$ & 47 & 23,5 \\
\hline & $\mathrm{Ne}$ & 138 & 69,0 \\
\hline & Ne vem & 15 & 7,5 \\
\hline \multirow[t]{3}{*}{ Programi za snemanje optičnih medijev } & $\mathrm{Da}$ & 88 & 44,0 \\
\hline & $\mathrm{Ne}$ & 97 & 48,5 \\
\hline & Ne vem & 15 & 7,5 \\
\hline \multirow[t]{3}{*}{ Programi za predvajanje multimedijskih vsebin } & $\mathrm{Da}$ & 74 & 37,0 \\
\hline & $\mathrm{Ne}$ & 106 & 53,0 \\
\hline & Ne vem & 20 & 10,0 \\
\hline \multirow[t]{3}{*}{ Programi za stiskanje datotek } & $\mathrm{Da}$ & 94 & 47,0 \\
\hline & $\mathrm{Ne}$ & 87 & 43,5 \\
\hline & Ne vem & 19 & 9,5 \\
\hline \multirow[t]{3}{*}{ Programi za prevajanje } & $\mathrm{Da}$ & 47 & 23,5 \\
\hline & $\mathrm{Ne}$ & 134 & 67,0 \\
\hline & Ne vem & 19 & 9,5 \\
\hline \multirow[t]{3}{*}{ Druge vrste programske opreme } & $\mathrm{Da}$ & 104 & 52,0 \\
\hline & $\mathrm{Ne}$ & 49 & 24,5 \\
\hline & Ne vem & 47 & 23,5 \\
\hline
\end{tabular}

OP ОM B E (1) odgovor, (2) povprečje, (3) standardni odklon.

nja nameščenosti piratskih različic je pri programih za CAD-oblikovanje $(23,5 \%)$ in programih za prevajanje $(23,5 \%)$. Najverjetneje gre to pripisati dejstvu, da na internetu obstaja veliko brezplačnih prevajalskih orodij.

$\mathrm{Na}$ osnovi podatkov, predstavljenih v preglednici 4.6, smo izračunali 
4 Piratstvo programske opreme - raziskava

Preglednica 4.7 Rangi po spolu

\begin{tabular}{lrrr}
\hline Spol & $N$ & Povprečni rang & Vsota rangov \\
\hline Moški & 111 & 107,20 & $11.899,0$ \\
Ženski & 89 & 92,15 & $8.201,0$ \\
Skupaj & 200 & & \\
\hline
\end{tabular}

povprečno nameščenost piratske programske opreme $\mathrm{v}$ preučevanem vzorcu, ki znaša 42,9\%. Povprečna nameščenost piratske programske opreme se glede na prejete odgovore iz posamezne države razlikuje. Medtem ko je ta v Sloveniji 42,6\%, je na vzorcu študentov iz Srbije $53,7 \%$, na vzorcu študentov iz Poljske $45,6 \%$ in na vzorcu študentov iz Velike Britanije 29,1\%.

\section{Nameščenost piratske programske opreme glede na spol}

S pridobljenimi podatki smo želeli ugotoviti, ali obstajajo statistično značilne razlike nameščenosti piratske programske opreme glede na spol anketiranih.

Delež vključenih anketirancev moškega spola znaša $55,5 \%$, delež anketirank pa znaša 44,5\%. Povprečna stopnja nameščenosti piratske programske opreme anketirancev moškega spola znaša 45,7\%, medtem ko je povprečna stopnja nameščenosti piratske programske opreme anketirank 39,3\%. Preverili smo, ali se povprečna nameščenost piratske programske opreme po skupinah (M, Ž) porazdeljuje normalno. Za ugotavljanje predpostavke o normalni porazdelitvi smo na podlagi Kolmogorov-Smirnovega testa in Shapiro-Wilkovega testa ugotovili, da se spremenljivka »Povprečna nameščenost piratske programske opreme« ne porazdeljuje normalno pri nobeni skupini (Sig. < 0,05). Zaradi kršene predpostavke o normalni porazdelitvi spremenljivke smo $\mathrm{v}$ nadaljevanju uporabili neparametrični test, ${ }^{8}$ Mann-Whitneyjev U-test. Vrednosti povprečnih in celotnih rangov so prikazane v preglednici 4.7.

Iz preglednice testnih statistik smo razbrali, da znaša stopnja značilnosti Sig. = o,o66. Glede na dejstvo, da je stopnja značilnosti večja od 0,05, ne moremo potrditi, da obstajajo statistično značilne razlike pri uporabi piratske programske opreme med anketiranimi osebami moškega in ženskega spola.

\footnotetext{
${ }^{8}$ Neparametrične teste se uporabi, ko ugotavljamo razlike med povprečnimi vrednostmi opisnih spremenljivk ali razlike med številskimi spremenljivkami, ki niso normalno porazdeljene (Šušter Erjavec in Južnik Rotar 2013, 135).
} 
Preglednica 4.8 Rangi po študijskem programu

\begin{tabular}{lrrr}
\hline Študijski program & $N$ & Povprečni rang & Vsota rangov \\
\hline 1. stopnja & 126 & 107,87 & $13 \cdot 591,5$ \\
2. stopnja & 74 & 87,95 & $6.508,5$ \\
Skupaj & 200 & & \\
\hline
\end{tabular}

\section{Nameščenost piratske programske opreme glede na stopnjo študija}

S pridobljenimi podatki smo želeli ugotoviti, ali obstajajo statistično značilne razlike nameščenosti piratske programske opreme glede na stopnjo študija anketiranih.

V vzorec je bilo vključenih 126 anketiranih študentov študijskih programov 1. stopnje in 74 anketiranih študentov študijskih programov 2. stopnje. Povprečna stopnja nameščenosti piratske programske opreme anketiranih študentov študijskih programov 1. stopnje znaša $46,4 \%$, medtem ko je povprečna stopnja nameščenosti piratske programske opreme anketiranih študentov študijskih programov 2. stopnje $36,8 \%$. Preverili smo, ali se povprečna nameščenost piratske programske opreme po skupinah porazdeljuje normalno. Na podlagi Kolmogorov-Smirnovega testa in Shapiro-Wilkovega testa smo ugotovili, da se spremenljivka »Povprečna nameščenost piratske programske opreme« ne porazdeljuje normalno pri nobeni skupini (Sig. < 0,05). Zaradi kršene predpostavke o normalni porazdelitvi spremenljivke smo v nadaljevanju za izvedbo raziskave opravili Mann-Whitneyjev U-test. Vrednosti povprečnih in celotnih rangov so prikazane v preglednici 4.8.

Iz preglednice testnih statistik smo razbrali, da znaša stopnja značilnosti Sig. = o,o18. Glede na dejstvo, da je stopnja značilnosti manjša od 0,05, lahko sklepamo, da obstajajo statistično značilne razlike pri uporabi piratske programske opreme med anketiranimi študenti študijskih programov 1. stopnje in študenti študijskih programov 2. stopnje. Študentje 2. stopnje študija imajo nižjo stopnjo nameščenosti piratske programske opreme.

\section{Nameščenost piratske programske opreme glede na državo prebivanja}

S Kruskal-Wallisovim testom (neparametrična oblika testa ANOVA) smo želeli preveriti, ali obstajajo statistično značilne razlike med stopnjo nameščenosti piratske programske opreme med študenti glede na državo bivanja (preglednica 4.9).

Pri stopnji značilnosti Sig. $=0,000$ smo ugotovili, da obstajajo stati- 
4 Piratstvo programske opreme - raziskava

Preglednica 4.9 Rangi po državah prebivanja

\begin{tabular}{lcrr}
\hline Država prebivanja & $N$ & Povprečni rang & Stopnja znač. \\
\hline Slovenija & 58 & 98,98 & 0,000 \\
Velika Britanija & 45 & 69,02 & \\
Poljska & 59 & 107,63 & \\
Srbija & 38 & 129,03 & \\
\hline
\end{tabular}

Preglednica 4.10 Man-Whitneyjev U-test (Slovenija, Velika Britanija)

\begin{tabular}{lrrrr}
\hline Država preb. & $N$ & Povprečni rangi & Vsota rangov & Stopnja znač. \\
\hline Slovenija & 58 & 58,43 & $3.389,00$ & 0,012 \\
Velika Britanija & 45 & 43,71 & $1.967,00$ & \\
\hline
\end{tabular}

Preglednica 4.11 Man-Whitneyjev U-test (Slovenija, Srbija)

\begin{tabular}{lrrrr}
\hline Država preb. & $N$ & Povprečni rangi & Vsota rangov & Stopnja znač. \\
\hline Slovenija & 58 & 42,97 & $2.492,00$ & 0,015 \\
Srbija & 38 & 56,95 & $2.164,00$ & \\
\hline
\end{tabular}

Preglednica 4.12 Man-Whitneyjev U-test (Slovenija, Poljska)

\begin{tabular}{lrrrr}
\hline Država preb. & $N$ & Povprečni rangi & Vsota rangov & Stopnja znač. \\
\hline Slovenija & 58 & 56,59 & $3.282,00$ & 0,442 \\
Poljska & 59 & 61,37 & $3.621,00$ & \\
\hline
\end{tabular}

stično značilne razlike med stopnjo nameščenosti piratske programske opreme med študenti glede na državo prebivanja.

V nadaljevanju nas je zanimalo, ali obstajajo statistično značilne razlike med stopnjo nameščenosti piratske programske opreme med slovenskimi študenti in anketiranimi študenti drugih držav. Analiza testov (preglednica 4.10) je pokazala, da pri stopnji značilnosti Sig. $=0,012$ lahko sklepamo, da obstajajo statistično značilne razlike v nameščenosti piratske programske opreme med anketiranimi slovenskimi študenti in tistimi iz Velike Britanije.

Ne moremo pa potrditi $($ Sig. $=0,442)$, da obstajajo statistično značilne razlike v nameščenosti piratske programske opreme med poljskimi in slovenskimi študenti (preglednica 4.12).

\section{Regresijska analiza vpliva tehnoloških dejavnikov na uporabo piratske programske opreme}

$\mathrm{Z}$ multiplo regresijsko analizo smo želeli preveriti linearni vpliv različnih dejavnikov na uporabo piratske programske opreme. Neodvisne 
Preglednica 4.13 Korelacijska matrika

\begin{tabular}{lcccr}
\hline Spremenljivke & 1. & 2. & 3. & 4. \\
\hline 1. Povprečna nameščenost piratske P O & & & & \\
2. IK T-pismenost študentov & $0,19^{* *}$ & & & \\
3. Prenos v omrežjih P 2 P & $0,43^{* *}$ & & & \\
4. Prenos neposredno z interneta & $0,39^{* *}$ & & $0,50^{* *}$ & \\
5. Vir namestitve piratske programske & $0,27^{* *}$ & $0,37^{* *}$ & $0,34^{* *}$ & $0,23^{* *}$ \\
opreme & & & & \\
\hline ОРОМВE ${ }^{* *}$ Statistično značilna korelacija pri $p=0,01$. & & &
\end{tabular}

spremenljivke, ki smo jih vključili v analizo, so: »I K T-pismenost študentov«, »Vir namestitve piratske programske opreme«, »Prenos v omrežjih P 2 P « in »Prenos piratskih vsebin $\mathrm{z}$ interneta«.

Medsebojno povezanost med spremenljivkami smo analizirali v korelacijski matriki (preglednica 4.13). Ugotovili smo, da obstajajo statistično značilne in pozitivne povezave med odvisno spremenljivko »Povprečna nameščenost piratske programske opreme« in neodvisnimi spremenljivkami »I K T-pismenost študentov« $(0,19)$, »Prenos v omrežjih P 2 P « $(0,43)$, "Prenos neposredno $z$ interneta $(0,39)$ in "Vir namestitve piratske programske opreme« $(0,27)$. Povezava med odvisno spremenljivko "Povprečna nameščenost piratske programske opreme« ter spremenljivkama "I K T-pismenost študentov« in »Vir namestitve piratske programske opreme « je šibka. Korelacija med odvisno spremenljivko in neodvisnima "Prenos v omrežjih P 2 P « in »Prenos neposredno $z$ interneta « je srednje močna in pozitivna. Na podlagi opisanih korelacijskih koeficientov lahko sklepamo, da se $\mathrm{z}$ rastjo neodvisnih spremenljivk uporaba piratske programske opreme povečuje. Vse povezave so statistično značilne.

Ugotovili smo, da so spremenljivke primerne za regresijsko analizo, kar smo preverili $\mathrm{z}$ analizo variance in izvedbo $F$-testa $($ Sig. $=0,00)$. Za analizo so primerne vse izbrane spremenljivke, kar je razvidno iz preglednice 4.14. Vsi parcialni korelacijski koeficienti beta so pozitivni in kažejo na pozitivno šibko povezanost med odvisno in posamezno neodvisno spremenljivko.

Multipli korelacijski koeficient $R$ (preglednica 4.15) znaša 0,56 , kar kaže na srednje močno odvisnost med odvisno spremenljivko "Stopnja nameščenosti piratske programske opreme« in vključenimi neodvisnimi spremenljivkami. Ocenjujemo, da je multipli determinacijski koeficient enak o,32, kar pomeni, da $32 \%$ variance odvisne spremenljivke 
Preglednica 4.14 Koeficienti

\begin{tabular}{lrrrrr}
\hline Postavka & $(1)$ & $(2)$ & $(3)$ & $(4)$ & $(5)$ \\
\hline Konstanta & $-0,30$ & 0,10 & & $-2,43$ & 0,02 \\
I K T-pismenost študentov & 0,07 & 0,03 & 0,17 & 2,75 & 0,01 \\
Prenos v omrežjih P 2 P & 0,04 & 0,02 & 0,16 & 2,45 & 0,02 \\
Prenos odjemalec - strežnik & 0,05 & 0,02 & 0,25 & 3,51 & 0,00 \\
Vir namestitve piratske pro- & 0,06 & 0,02 & 0,25 & 3,48 & 0,00 \\
gramske opreme & & & & & \\
\hline
\end{tabular}

OPOмвE (1) B, (2) standardna napaka (standardizirana koefifienta), (3) beta (nestandardizirani koeficient), (4) $t$, (5) stopnja značilnosti. Odvisna spremenljivka - stopnja nameščenosti piratske programske opreme.

Preglednica 4.15 Rezultati regresijske analize

\begin{tabular}{llll}
\hline$R$ & $R^{2}$ & Popravljeni $R^{2}$ & Ocena standardne napake \\
\hline 0,56 & 0,32 & 0,30 & 0,21 \\
\hline
\end{tabular}

OРОМве Odvisna spremenljivka: stopnja nameščenosti piratske programske opreme.

Neodvisne spremenljivke: IK T-pismenost, Prenos s strani P2 P, Prenos s strani s piratsko vsebino, Vir namestitve.

lahko pojasnimo $\mathrm{z}$ linearnim vplivom neodvisnih spremenljivk »I K Tpismenost študentov«, »Prenos P 2 P «, »Prenos neposredno z interneta« in »Vir namestitve piratske programske opreme«. Preostalih $68 \%$ variance povzročajo neznani ali naključni dejavniki.

Neodvisne spremenljivke: IK T-pismenost, Prenos s strani P 2P, Prenos s strani s piratsko vsebino, Vir namestitve.

\section{Dejavniki uporabe in odvrnitve od uporabe piratske programske opreme}

V nadaljevanju smo želeli izvedeti, kateri dejavniki vplivajo na odločitev posameznika za uporabo piratske programske opreme. ${ }^{9}$ Odgovori anketirancev so predstavljeni v preglednici 4.16. Iz prejetih odgovorov smo ugotovili, da so anketiranci kot najpomembnejši dejavnik, ki vpliva na namestitev piratske programske opreme, ovrednotili »Visoke cene komercialne programske opreme« $(M=4,1)$.

S povprečno oceno $M=3,9$ so anketiranci ovrednotili dejavnik »Piratska programska oprema je brezplačna«in trditev, da se zavedajo protiza-

${ }^{9}$ Anketiranci so trditve $\mathrm{v}$ povezavi z dejavniki uporabe piratske programske opreme ovrednotili na petstopenjski lestvici, pri čemer je ocena 5 pomenila "popolnoma se strinjam«, ocena 1 pa "sploh se ne strinjam«. 
Preglednica 4.16 Dejavniki uporabe piratske programske opreme

\begin{tabular}{lrr}
\hline Spremenljivke & $(1)$ & $(2)$ \\
\hline Komercialna programska oprema je predraga. & 4,1 & 1,1 \\
Piratska programska oprema je brezplačna. & 3,9 & 1,3 \\
Zavedam se protizakonitosti uporabe piratske programske opreme. & 3,9 & 1,1 \\
V izobraževalnem procesu smo vedno uporabljali komercialno & 3,8 & 1,1 \\
programsko opremo. & 3,6 & 1,1 \\
Piratski programi so enake kakovosti kot tisti, ki jih kupimo. & 3,4 & 1,2 \\
$\begin{array}{l}\text { Piratska programska oprema je preprosto dostopna prek omrežij } \\
\text { P 2 P. }\end{array}$ & 3,2 & 1,2 \\
$\begin{array}{l}\text { Ob prenosu piratskih vsebin z interneta lahko prejmem in namestim } \\
\text { računalniške viruse. }\end{array}$ & 3,1 & 1,1 \\
Izobraževalni proces mi je dal dovolj veščin za uporabo B P O. & 2,6 & 1,2 \\
$\begin{array}{l}\text { Z uporabo piratske programske opreme ne povzročam škode } \\
\text { nikomur. }\end{array}$ & 2,5 & 1,2 \\
Piratska programska oprema je prosto dostopna, saj je na internetu. & 2,4 & 1,1 \\
Piratski programi, ki so dostopni na internetu, so javni in jih smem & & \\
uporabljati. & 2,3 & 1,1 \\
Bojim se, da bodo organi pregona odkrili moje nezakonito početje. &
\end{tabular}

OP OMBE (1) povprečje, (2) standardni odklon.

konitosti uporabe piratske programske opreme. Ob tem so s povprečno oceno $\mathrm{M}=2,3$ ocenili trditev, da se bojijo, da bi jih organi pregona odkrili pri njihovem početju, kar je bilo ocenjeno $\mathrm{z}$ najnižjo povprečno oceno med trditvami.

V povezavi s trditvami o nezakonitosti uporabe piratske programske opreme so anketiranci ocenjevali tudi trditve o dopustnosti uporabe piratske programske opreme glede na dejstvo, da se jo da v praksi prosto prenesti z interneta. Anketiranci so trditev, da so piratski programi, ki so dostopni na internetu, javni in jih smejo uporabljati, ocenili s povprečno oceno $M=2,4$. Anketiranci so podobno s povprečno oceno $M$ $=2,6$ ocenili tudi trditev, da $\mathrm{z}$ uporabo piratske programske opreme ne povzročajo škode nikomur.

Iz tega lahko sklepamo, da kljub zavedanju protizakonitosti svojega početja anketirani študentje ne občutijo tveganja kaznovanosti, kar nedvomno pripomore $\mathrm{k}$ višji stopnji uporabe piratske programske opreme. Navedeno dejstvo potrjujejo tudi ugotovitve, ki smo jih predstavili v prvem delu monografije. Povprečne ocene preostalih dejavnikov uporabe piratske programske opreme so razvidne v preglednici 4.16.

$\mathrm{Z}$ anketo smo želeli pridobiti tudi podatke o dejavnikih, ki bi zmanj- 
Preglednica 4.17 Dejavniki zmanjševanja uporabe piratske programske opreme

\begin{tabular}{lll}
\hline Spremenljivke & $(1)$ & $(2)$ \\
\hline Nižje cene komercialne programske opreme & 4,7 & 0,6 \\
Uvedba tehnične zaščite proti kopiranju programske opreme & 3,2 & 1,3 \\
Aktivacija programa na strežnikih proizvajalca programske opreme & 3,1 & 1,2 \\
Omejitev hitrosti prenosa internetnih podatkov ob zlorabah prenosa & 3,0 & 1,2 \\
Strožja zakonodaja na področju uporabe piratske programske & 2,9 & 1,2 \\
opreme & & \\
Višje sankcije (kazni) za uporabo piratske programske opreme & 2,9 & 1,2 \\
Uvedba nadzora uporabe interneta od ISP & 2,9 & 1,2 \\
\hline
\end{tabular}

OР Ом Ве (1) povprečje, (2) standardni odklon.

ševali stopnjo uporabe piratske programske opreme. ${ }^{10}$ Odgovori anketirancev so predstavljeni v preglednici 4.17.

Najpomembnejši dejavnik, ki bi po mnenju anketirancev zmanjšal uporabo piratske programske opreme, so nižje cene komercialne programske opreme. Ta odgovor so anketiranci v povprečju ovrednotili z oceno $\mathrm{M}=4,7$. Najvišjo mogočo oceno 5 so temu dejavniku dodelile skoraj tri četrtine anketiranih (74,5\%).

Anketiranci so s povprečno oceno vsaj 3 ocenili dejavnike »Uvedba tehnične zaščite pri kopiranju programske opreme« $(M=3,2)$, »Aktivacija programa na strežnikih proizvajalca programske opreme« $(M=3,1)$ in "Omejitev hitrosti prenosa internetnih podatkov ob zlorabah prenosa" $(M=3,0)$.

Podrobnejši prikaz preostalih dejavnikov zmanjševanja uporabe piratske programske opreme je prikazan v preglednici 4.17.

\section{Faktorska analiza dejavnikov uporabe in odvrnitve od uporabe piratske programske opreme}

S faktorsko analizo skušamo ugotoviti, ali lahko zveze med spremenljivkami pojasnimo s skupnimi razsežnostmi oziroma faktorji (Ferligoj 2003). S faktorsko analizo smo želeli ugotoviti, ali obstajajo skupni dejavniki, ki vplivajo na uporabo piratske programske opreme in na odvrnitev od uporabe piratske programske opreme pri anketirani populaciji.

\footnotetext{
${ }^{10}$ Anketiranci so postavljene trditve ocenjevali po petstopenjski Likertovi lestvici, pri če-
} mer je ocena 5 pomenila "popolnoma se strinjam«, ocena 1 pa »sploh se ne strinjam«. 


\section{Faktorska analiza dejavnikov uporabe piratske programske opreme}

Spremenljivke, vključene $\mathrm{v}$ faktorsko analizo dejavnikov, ki vplivajo na uporabo piratske programske opreme, smo pridobili na podlagi odgovorov na vprašanji 3 in $6 \mathrm{v}$ anketnem vprašalniku (priloga 1). $V$ analizo smo tako skupaj vključili 19 vprašanj.

Medsebojno odvisnost med 19 spremenljivkami (preglednici 4.13 in 4.14) smo najprej preverili v korelacijski matriki. Iz analize smo izločili spremenljivke $z$ nizkim korelacijskim koeficientom (manjši od $o, 3$ ), ${ }^{11}$ kar kaže na šibko in neznačilno povezanost $\mathrm{z}$ drugimi spremenljivkami. $\mathrm{V}$ teh primerih vplivov skupnih faktorjev ne pričakujemo.

Ugotovili smo, da je najmočnejša premosorazmerna povezanost med spremenljivkami "Višje kazni« in "Nadzor IS P« $(0,73)$, "Strožja zakonodaja in »Višje kazni« $(0,70)$, "Strožja zakonodaja« in »Nadzor IS P« $(0,62)$, "Strožja zakonodaja« in »Uvedba tehnične zaščite« $(0,66)$. Srednje močne stopnje povezanosti smo zaznali med spremenljivkama »Piratska programska oprema je brezplačna« in "Komercialna programska oprema je predraga « $(0,53)$ ter med spremenljivkama »Piratska programska oprema je brezplačna in »Piratska programska oprema je preprosto dostopna $(0,51)$. Srednje močne stopnje povezanosti smo zaznali tudi med spremenljivkami »Piratski programi, ki so dostopni na internetu, so javni in jih smem uporabljati« ter " $Z$ uporabo piratske programske opreme ne povzročam škode nikomur« $(0,57)$.

$S$ pomočjo Kaiser-Meyer-Olkinovega testa (K MO) smo preverili, ali so podatki primerni za faktorsko analizo. Ugotovili smo, da K M O znaša o,803, stopnja značilnosti Bartlettovega testa Sig. $=$ o,ooo, kar pomeni, da so podatki primerni. Oceno komunalitet dejavnikov uporabe piratske programske opreme prikazujemo v preglednici 4.18.

$\mathrm{Z}$ analizo faktorske matrike smo ugotovili, da sta prvi in tretji faktor izrazito bipolarna ter da pri drugem faktorju nobena spremenljivka nima izrazite faktorske uteži. Zato smo se odločili, da izvedemo rotacijo faktorjev ${ }^{12}$ ki smo jo izvedli z metodo Varimax. Po izvedeni rotaciji smo ugotovili, da se delež celotne pojasnjene variance ni spremenil, spre-

${ }^{11}$ Korelacijski koeficient meri linearno povezanost in moč povezanosti med spremenljivkama, pri čemer vrednost od o do $|0,3|$ pomeni šibko povezanost, nad $|0,3|$ do $|0,6|$ srednje močno povezanost, nad $|0,6|$ do $|1|$ pa zelo močno povezanost (Šušter Erjavec in Južnik Rotar 2013, 88).

${ }^{12}$ Rotacijo faktorjev izvedemo zato, da dobimo teoretično pomembne faktorje in poenostavitev faktorske strukture (Ferligoj 2003). 
4 Piratstvo programske opreme - raziskava

Preglednica 4.18 Ocena komunalitet dejavnikov uporabe piratske programske opreme

\begin{tabular}{|c|c|c|c|c|c|c|}
\hline \multicolumn{4}{|c|}{ Spremenljivke } & & \multicolumn{2}{|c|}{ Komunalitete } \\
\hline \multicolumn{6}{|c|}{ Piratska programska oprema je brezplačna. } & 0,805 \\
\hline \multicolumn{6}{|c|}{ Komercialna programska oprema je predraga. } & 0,710 \\
\hline \multicolumn{6}{|c|}{ Piratska programska oprema je prosto dostopna, saj je na internetu. } & 0,779 \\
\hline \multicolumn{6}{|c|}{$\mathrm{Z}$ uporabo piratske programske opreme ne povzročam škode nikomur. } & 0,706 \\
\hline \multicolumn{6}{|c|}{ Piratska programska oprema je preprosto dostopna na omrežjih P 2 P. } & 0,649 \\
\hline \multicolumn{6}{|c|}{$\begin{array}{l}\text { Piratski programi, ki so dostopni na internetu, so javni in jih smem } \\
\text { uporabljati. }\end{array}$} & 0,690 \\
\hline \multicolumn{6}{|c|}{ Uvedba tehnične zaščite bi zmanjšala uporabo piratske programske opreme. } & 0,629 \\
\hline \multicolumn{6}{|c|}{ Strožja zakonodaja bi zmanjšala uporabo piratske programske opreme. } & 0,751 \\
\hline \multicolumn{6}{|c|}{ Višje kazni bi zmanjšale uporabo piratske programske opreme. } & 0,776 \\
\hline \multicolumn{6}{|c|}{ Nadzor IS P bi zmanjšal uporabo piratske programske opreme. } & 0,768 \\
\hline \multicolumn{6}{|c|}{ Omejitev hitrosti prenosa ob kršitvah bi zmanjšala uporabo piratske PO. } & 0,629 \\
\hline \multicolumn{7}{|c|}{ Preglednica 4.19 Celotna pojasnjena varianca } \\
\hline \multirow[t]{2}{*}{ Faktor } & \multicolumn{3}{|c|}{ Začetne vrednosti } & \multicolumn{3}{|c|}{ Vsote po rotaciji } \\
\hline & (1) & (2) & (3) & (1) & (2) & (3) \\
\hline 1 & 3,814 & 34,675 & 34,675 & 3,405 & 30,953 & 30,953 \\
\hline 2 & 3,032 & 27,563 & 62,238 & 2,273 & 20,666 & 51,619 \\
\hline 3 & 1,044 & 9,488 & 71,726 & 2,212 & 20,107 & 71,726 \\
\hline 4 & 0,650 & 5,910 & 77,636 & & & \\
\hline 5 & 0,549 & 4,988 & 82,624 & & & \\
\hline 6 & 0,452 & 4,108 & 86,732 & & & \\
\hline 7 & 0,419 & 3,812 & 90,544 & & & \\
\hline 8 & 0,319 & 2,895 & 93,439 & & & \\
\hline 9 & 0,295 & 2,680 & 96,119 & & & \\
\hline 10 & 0,237 & 2,158 & 98,277 & & & \\
\hline 11 & 0,190 & 1,723 & 100,000 & & & \\
\hline
\end{tabular}

OР Ом в Е (1) skupaj, (2) delež variance v odstotkih, (3) kumulativni delež variance v odstotkih.

menile so se lastne vrednosti faktorjev in deleži variance. Spremenjene vrednosti prikazujemo v preglednici 4.20.

$\mathrm{V}$ preglednici 4.21 prikazujemo faktorsko matriko dejavnikov uporabe piratske programske opreme.

Spremenljivke »Uvedba tehnične zaščite«, "Strožja zakonodaja«, »Višje kazni«, »Nadzor IS P« in »Omejitev hitrosti« imajo pri prvem faktorju visoke faktorske uteži. S prvim faktorjem lahko pojasnimo 31,0 \% celo- 
Preglednica 4.20 Pojasnjena varianca po rotaciji

\begin{tabular}{lrrr}
\hline Faktor & $(1)$ & $(2)$ & $(3)$ \\
\hline 1 & 3,405 & 31,0 & 31,0 \\
2 & 2,273 & 20,7 & 51,6 \\
3 & 2,212 & 20,1 & 71,7 \\
\hline
\end{tabular}

OРОМвЕ (1) lastna vrednost, (2) delež variance v odstotkih, (3) kumulativni delež variance $v$ odstotkih.

Preglednica 4.21 Faktorska struktura dejavnikov po rotaciji faktorjev

\begin{tabular}{lrrr}
\hline Dejavniki & \multicolumn{3}{c}{ Faktor } \\
\cline { 2 - 4 } & $-0,018$ & 0,855 & 0,272 \\
\hline Piratska P O brezplačna & $-0,145$ & 0,799 & 0,225 \\
Komercialna predraga & 0,029 & 0,275 & 0,838 \\
Pravico imam, ker z interneta & $-0,117$ & 0,302 & 0,775 \\
Ne povzročam škode & $-0,082$ & 0,752 & 0,276 \\
Preprosto dostopna & 0,084 & 0,184 & 0,806 \\
Piratska PO javna, ker je na internetu & 0,769 & $-0,187$ & 0,056 \\
Tehnična zaščita & 0,817 & $-0,248$ & 0,147 \\
Strožja zakonodaja & 0,879 & $-0,046$ & 0,026 \\
Višje kazni & 0,872 & $-0,059$ & $-0,059$ \\
Nadzor I P & 0,750 & 0,192 & $-0,170$ \\
Omejitev hitrosti & &
\end{tabular}

tne variance. Spremenljivka »Višje kazni« ima najvišjo vrednost faktorskih uteži (o,879), sledita »Nadzor IS P« (o,872) in »Strožja zakonodaja« $(0,817)$. Glede na vključene spremenljivke in njihovo povezanost z zakonodajnimi ukrepi in uvedbo tehnične zaščite bomo tudi na podlagi ugotovitev teoretičnega dela prvi faktor poimenovali »Tveganje kaznovanosti«.

Pri drugem faktorju imajo visoke faktorske uteži spremenljivke »Piratska programska oprema je brezplačna«, »Komercialna programska oprema je predraga « in »Piratska programska oprema je preprosto dostopna na P 2 P«. Najvišjo faktorsko utež ima prva spremenljivka, »Piratska programska oprema je brezplačna « $(0,855)$, ki zelo dobro predstavlja vsebino drugega faktorja, s katerim lahko pojasnimo 20,7-odstotni delež celotne variance. Glede na vključene spremenljivke lahko drugi faktor tudi na podlagi ugotovitev teoretičnega dela poimenujemo »Cena in preprostost operacij«.

Tretji faktor, s katerim pojasnimo $20,1 \%$ celotne variance, ima vi- 
soke faktorske uteži pri treh spremenljivkah. Najvišjo faktorsko utež ima spremenljivka »Piratska programska oprema je prosto dostopna, saj je na internetu« (o,838), sledita ji spremenljivki »Piratski programi, ki so dostopni na internetu, so javni in jih smem uporabljati« $(0,806)$ ter "Z uporabo piratske programske opreme ne povzročam škode nikomur« $(0,775)$. Glede na vključene spremenljivke $z$ visokimi faktorskimi utežmi in ugotovitve teoretičnega dela lahko tretji faktor poimenujemo "Moralni razlogi, ozaveščenost in avtorjeva oddaljenost«.

Na podlagi rezultatov faktorske analize dejavnikov uporabe in odvrnitve od uporabe piratske programske opreme smo ugotovili, da so za anketirance pri odločanju o uporabi piratske programske opreme pomembni trije dejavniki:

- zakonodaja in nadzor nad uporabo piratske programske opreme, pri čemer najverjetneje prav pomanjkanje nadzora in neučinkovitost organov pregona omogočata večjo uporabo piratske programske opreme;

- cena in preprosta dostopnost piratske programske opreme;

- prosta dostopnost in odsotnost moralnih vrednot anketiranih študentov.

\section{Vpliv dejavnikov za uporabo piratske programske opreme med študenti po državah}

S Kruskal-Wallisovim testom smo želeli preveriti, ali med študenti po državah obstajajo statistično značilne razlike med dejavniki, ki vplivajo na uporabo piratske programske opreme.

$\mathrm{V}$ analizo smo vključili 7 dejavnikov (preglednica 4.22), ki so izkazovali statistično značilno pozitivno povezanost s spremenljivko »Povprečna nameščenost piratske programske opreme«. Ugotovili smo (preglednica 4.23), da med anketiranimi študenti, glede na državo prebivanja, ni statistično značilnih razlik med dejavniki za uporabo piratske programske opreme.

\section{Uporaba odprtokodne in brezplačne programske opreme}

V povezavi z namestitvijo odprtokodne in brezplačne programske opreme smo anketirance vprašali, ali imajo tovrstno opremo nameščeno na svojih računalnikih. Iz prejetih odgovorov smo izračunali, da ima $75,5 \%$ anketirancev na svojem računalniku nameščeno В Р О in O P O. 
Preglednica 4.22 Primerjani dejavniki uporabe piratske programske opreme

\begin{tabular}{lr}
\hline Dejavniki & Stopnja značilnosti \\
\hline Piratska programska oprema je brezplačna. & 0,070 \\
Komercialna programska oprema je predraga. & 0,855 \\
Piratski programi so enake kakovosti kot tisti, ki jih kupimo. & 0,550 \\
Piratska programska oprema je prosto dostopna, saj je na internetu. & 0,104 \\
Z uporabo piratske programske opreme ne povzročam škode nikomur. & 0,477 \\
Piratska programska oprema je preprosto dostopna prek omrežij P 2 P. & 0,576 \\
Pir. prog., ki so dostopni na internetu, so javni in jih smem uporabljati. & 0,499 \\
\hline
\end{tabular}

Na vprašanje, ali menijo, da B P O in O P O lahko popolnoma nadomestita komercialno ali piratsko programsko opremo, je 61,0\% anketiranih podalo mnenje, da B P O in O PO ne moreta popolnoma nadomestiti komercialne ali piratske programske opreme.

Anketiranci so odgovarjali tudi na vprašanja, povezana $\mathrm{z}$ oceno o ustreznosti brezplačnih ali odprtokodnih programov za nadomeščanje komercialne programske opreme. ${ }^{13}$ Podali smo 9 primerjav splošno uporabljene programske opreme (preglednica 4.30) in ugotovili, da so anketiranci najvišjo oceno nadomestljivosti $(M=4,3)$ namenili internetnima brskalnikoma Mozilla Firefox in Google Chrome, ki lahko nadomestita privzeti program komercialnega operacijskega sistema Windows Internet Explorer. ${ }^{14}$ Anketiranci so $\mathrm{z}$ oceno $\mathrm{M}>4$, $\mathrm{O}$ ocenili, da program »VLC player« lahko nadomesti »Windows Media Player« ter da odprtokodni program za stiskanje datotek »7zip« lahko nadomesti komercialna programa »WinZip« in »Win RAR«.

Povezava med ocenami spremenljivk o nadomeščanju komercialne programske opreme z O PO in B P O je prikazana v preglednici 4.24. Ker spremenljivke niso normalno porazdeljene, smo moč linearne povezanosti med njimi izračunali s pomočjo Spearmanovega koeficienta korelacije. Ugotovili smo, da najmočnejše povezanosti obstajajo med spremenljivkama (1) »Operacijski sistemi« in (2) »Pisarniški paketi« $(0,76)$. Zelo močne povezanosti so ugotovljene tudi med spremenljivkama (9) »Programi za stiskanje datotek« in (8) »Programi za predvajanje multi-

${ }^{13}$ Odgovori so bili podani na 5-stopenjski Likertovi lestvici, pri čemer je ocena 5 pomenila "popolnoma lahko nadomesti«, ocena 1 pa "sploh ne more nadomestiti«.

${ }^{14}$ Program Internet Explorer se namesti kot dodatek operacijskega sistema Windows. Zanj veljajo licenčni pogoji operacijskega sistema Windows, zato se predvideva, da gre za komercialno programsko opremo; glej http://windows.microsoft.com/sl-si/internet -explorer/ie11-software-license-terms. 
4 Piratstvo programske opreme - raziskava

Preglednica 4.23 Nadomeščanje programske opreme z OP O

\begin{tabular}{lcc}
\hline Spremenljivke & $(1)$ & $(2)$ \\
\hline Firefox, Chrome : Internet Explorer & 4,3 & 0,9 \\
VLC Player : Windows Media Player & 4,0 & 1,0 \\
7 Zip : Win Zip, Win RA R & 4,0 & 1,0 \\
Antivirus Avira, Avast, AV G : N O D 32, Norton, Kaspersky & 3,7 & 1,1 \\
Thunderbird : Outlook Express & 3,7 & 1,0 \\
CD Burner XP, I M G burn : Nero Burning Room & 3,6 & 1,0 \\
LibreOffice : Microsoft Office & 3,4 & 1,1 \\
Unix (Linux, Ubuntu) : Windows & 3,1 & 1,2 \\
Gimp, Paint.net : Photoshop & 3,1 & 1,1 \\
\hline
\end{tabular}

OР ОМ ВE (1) povprečje, (2) standardni odklon.

Preglednica 4.24 Nadomeščanje programske opreme z O PO

\begin{tabular}{|c|c|c|c|c|c|c|c|c|}
\hline Spremenljivke & 1. & 2. & 3. & 4. & 5. & 6. & 7. & 8. \\
\hline 1. Linux, Ubuntu : Windows & & & & & & & & \\
\hline $\begin{array}{l}\text { 2. LibreOffice : Microsoft } \\
\text { Office }\end{array}$ & $0,76^{*}$ & & & & & & & \\
\hline $\begin{array}{l}\text { 3. Avira, Avast : NOD32, } \\
\text { Norton }\end{array}$ & & & & & & & & \\
\hline $\begin{array}{l}\text { 4. Firefox, Chrome : Internet } \\
\text { Explorer }\end{array}$ & & & & & & & & \\
\hline $\begin{array}{l}\text { 5. Thunderbird : Outlook } \\
\text { Express }\end{array}$ & & & & $0,50^{*}$ & & & & \\
\hline $\begin{array}{l}\text { 6. Gimp, Paint.net: } \\
\text { Photoshop }\end{array}$ & $0,52^{*}$ & & & & & & & \\
\hline $\begin{array}{l}\text { 7. CD Burner XP : Nero } \\
\text { Burning Room }\end{array}$ & & & $0,58^{*}$ & $0,51^{*}$ & $0,63^{*}$ & & & \\
\hline $\begin{array}{l}\text { 8. V LC Player : Windows } \\
\text { Media Player }\end{array}$ & & & $0,52^{*}$ & $0,62^{*}$ & $0,53^{*}$ & & $0,59^{*}$ & \\
\hline 9. 7 Zip : Win Zip, Win RAR & & & $0,53^{*}$ & $0,56^{*}$ & $0,53^{*}$ & & $0,61^{*}$ & $0,72^{*}$ \\
\hline
\end{tabular}

оромв Opomba: *statistično značilna razlika pri $p=0,01$.

medijskih vsebin« $(0,72)$. Vse korelacijske povezave so pozitivne in statistično značilne.

Anketirancem smo v vprašalniku postavili 10 trditev, ki so se nanašale na vzroke za (ne)nadomeščanje komercialne programske opreme $\mathrm{z}$ В РО in OP O. ${ }^{15}$ Najvišje so anketiranci ocenili trditev, da B PO in O PO

${ }^{15}$ Trditve so ocenjevali na 5-stopenjski Likertovi lestvici, pri čemer je ocena 5 pomenila "popolnoma se strinjam", ocena 1 pa "sploh se ne strinjam«. 
Preglednica 4.25 Dejavniki, ki vplivajo na nadomeščanje komercialne PO $\mathrm{z}$ OPO in BPO

\begin{tabular}{lcc}
\hline Spremenljivke & $(1)$ & $(2)$ \\
\hline Ne nudi vseh funkcionalnosti kot komercialna programska oprema. & 3,5 & 1,0 \\
Večina mojih kolegov uporablja komercialno (piratsko) programsko & 3,3 & 1,1 \\
opremo. & 3,3 & 1,1 \\
Z B PO se večkrat namestijo reklamni programi. & 3,2 & 1,0 \\
Ni združljiva s komercialno (piratsko) programsko opremo. & 3,2 & 1,1 \\
Ne znam je uporabljati v tolikšni meri kot komercialno programsko & & \\
opremo. & 3,1 & 1,1 \\
V okviru šolanja smo se učili uporabljati izključno komercialno & & \\
programsko opremo. & 3,0 & 1,0 \\
B P O ne zagotavlja enake stopnje tehnične podpore kot komercialna. & 2,7 & 1,1 \\
Na voljo je manj možnosti izobraževanja za B P O. & 2,3 & 1,1 \\
B P O ni v domačem jeziku. & 2,1 & 1,1 \\
Pomoč za uporabo B PO ni dostopna v domačem jeziku. & &
\end{tabular}

оромве (1) povprečje, (2) standardni odklon.

ne nudita vseh funkcionalnosti, ki jih nudi komercialna programska oprema $(M=3,5)$.

Anketiranci so $\mathrm{z}$ drugo najvišjo povprečno oceno $\mathrm{M}=3,3$ ocenili tudi dejavnika »Večina mojih kolegov uporablja komercialno programsko opremo« in » $Z$ B P O se večkrat namestijo reklamni programi«. Podrobneje je ocenjevanje razlogov za (ne)nadomeščanje komercialne programske opreme z O РО in B PO predstavljeno v preglednici 4.25 .

\section{Faktorska analiza dejavnikov nadomeščanja programske opreme}

Spremenljivke, vključene $\mathrm{v}$ faktorsko analizo dejavnikov, ki vplivajo na nadomeščanje komercialne ali piratske programske opreme z B PO in OPO, smo pridobili s prejetimi ocenami anketirancev na 10 postavljenih trditev v 10. točki anketnega vprašalnika (priloga 1). Skupaj smo v analizo vključili 8 trditev.

Medsebojno odvisnost med 10 spremenljivkami (preglednica 4.17) smo najprej preverili v korelacijski matriki. Spremenljivke niso bile normalno porazdeljene, zato smo moč linearne povezanosti med njimi izračunali s pomočjo Spearmanovega koeficienta korelacije. Iz analize smo izločili spremenljivke $\mathrm{z}$ nizkim korelacijskim koeficientom (manjši od o,3), kar kaže na šibko povezanost $z$ drugimi spremenljivkami. V teh primerih vplivov skupnih faktorjev ne pričakujemo.

Ugotovili smo, da je najmočnejša premosorazmerna povezanost med 
4 Piratstvo programske opreme - raziskava

Preglednica 4.26 Ocena komunalitet dejavnikov nadomeščanja programske opreme

\begin{tabular}{lr}
\hline Spremenljivke & Komunalitete \\
\hline Ni združljiva s komercialno (piratsko) programsko opremo. & 0,779 \\
Ne nudi vseh funkcionalnosti kot komercialna programska oprema. & 0,728 \\
Ne znam je uporabljati v tolikšni meri kot komercialno programsko & 0,567 \\
opremo. & \\
V okviru šolanja smo se učili uporabljati samo komercialno programsko & 0,695 \\
opremo. & \\
Večina mojih kolegov uporablja komercialno programsko opremo. & 0,710 \\
B PO in OPO nista dostopna v domačem jeziku. & 0,749 \\
Na voljo je manj možnosti izobraževanja za B P O. & 0,564 \\
Pomoč za uporabo B P O in O o o ni dostopna v domačem jeziku. & 0,778 \\
\hline
\end{tabular}

spremenljivkama »BPO in OPO nista dostopna v domačem jeziku“ in "Pomoč za uporabo B PO in OPO ni dostopna v domačem jeziku« $(0,63)$. Srednje močne premosorazmerne povezanosti smo zaznali med spremenljivkami »Ni združljiva s komercialno (piratsko) programsko opremo « in "Ne nudi vseh funkcionalnosti kot komercialna programska oprema« (o,50). Enako povezanost smo zaznali med spremenljivkama "Večina mojih kolegov uporablja komercialno programsko opremo« in "V okviru šolanja smo se učili uporabljati samo komercialno programsko opremo« $(0,49)$. Srednje močno povezanost smo zaznali tudi med spremenljivkama »V okviru šolanja smo se učili uporabljati samo komercialno programsko opremo « in »Ne znam je uporabljati v tolikšni meri kot komercialno programsko opremo« $(0,45)$.

$S$ pomočjo Kaiser-Meyer-Olkinovega (K MO) testa smo preverili, ali so podatki primerni za faktorsko analizo. Ugotovili smo, da K M O znaša o,672, stopnja značilnosti Bartlettovega testa Sig. = o,ooo, kar pomeni, da so podatki primerni. Oceno komunalitet dejavnikov nadomeščanja programske opreme prikazujemo v preglednici 4.26.

Faktorski model smo ocenili s pomočjo metode glavnih osi. Število faktorjev (3) je bilo izbrano na podlagi merila lastne vrednosti, ki je pri prvih treh faktorjih večji od ena (preglednica 4.27). Prav tako je delež celotne pojasnjene variance s tremi faktorji $69,6 \%$, kar je nad predpisanimi $60 \%$. Delež pojasnjene variance $(69,6 \%)$ nam dodatno potrjuje, da $\mathrm{v}$ analizi obdržimo tri faktorje.

Lastna vrednost prvega faktorja znaša 2,8; z njim lahko pojasnimo $34,9 \%$ celotne variance. Drugi faktor ima lastno vrednost 1,5 in pojasni 
Preglednica 4.27 Celotna pojasnjena varianca

\begin{tabular}{lrrrrrrr}
\hline Faktor & \multicolumn{3}{c}{ Začetne vrednosti } & & \multicolumn{3}{c}{ Vsote po rotaciji } \\
\cline { 2 - 4 } \cline { 6 - 8 } & $(1)$ & $(2)$ & $(3)$ & & $(1)$ & $(2)$ & $(3)$ \\
\hline 1 & 2,792 & 34,901 & 34,901 & & 2,072 & 25,898 & 25,898 \\
2 & 1,479 & 18,488 & 53,389 & & 1,916 & 23,954 & 49,852 \\
3 & 1,300 & 16,251 & 69,639 & & 1,583 & 19,788 & 69,639 \\
4 & 0,653 & 8,166 & 77,805 & & & \\
5 & 0,577 & 7,213 & 85,018 & & & \\
6 & 0,493 & 6,157 & 91,175 & & & \\
7 & 0,367 & 4,592 & 95,767 & & & \\
8 & 0,339 & 4,233 & 100,000 & & & & \\
\hline
\end{tabular}

О Р Ом в Е (1) skupaj, (2) delež variance v odstotkih, (3) kumulativni delež variance v odstotkih.

Preglednica 4.28 Pojasnjena varianca po rotaciji

\begin{tabular}{lrrr}
\hline Faktor & $(1)$ & $(2)$ & $(3)$ \\
\hline 1 & 2,072 & 25,9 & 25,9 \\
2 & 1,916 & 23,9 & 49,8 \\
3 & 1,583 & 19,8 & 69,6 \\
\hline
\end{tabular}

ОРОМВЕ (1) lastna vrednost, (2) delež variance v odstotkih, (3) kumulativni delež variance v odstotkih.

$18,5 \%$ variance, tretji faktor pa ima lastno vrednost 1,3 in pojasni $16,2 \%$ celotne variance (preglednica 4.27).

Po izračunu faktorske matrike smo ugotovili, da pri prvem faktorju nobena spremenljivka nima izrazite faktorske uteži; drugi in tretji faktor sta izrazito bipolarna. Zato smo se odločili, da izvedemo rotacijo faktorjev. Izvedli smo jo po metodi Varimax.

Po izvedeni rotaciji ugotavljamo, da se delež celotne pojasnjene variance ni spremenil, spremenili so se lastne vrednosti faktorjev in deleži variance. Spremenjene vrednosti prikazujemo v preglednici 4.28.

Faktorsko matriko dejavnikov nadomeščanja komercialne programske opreme z В РО in ОР О prikazujemo v preglednici 4.29.

Spremenljivke »V okviru šolanja smo se učili uporabljati samo komercialno programsko opremo«, „Večina mojih kolegov uporablja komercialno programsko opremo « in "Ne znam je uporabljati v tolikšni meri kot komercialno programsko opremo« imajo pri prvem faktorju visoke faktorske uteži. S prvim faktorjem lahko pojasnimo $25,9 \%$ celotne variance. Spremenljivki $» V$ okviru šolanja smo se učili uporabljati samo komercialno programsko opremo" in "Večina mojih kolegov uporab- 
Preglednica 4.29 Faktorska struktura dejavnikov po rotaciji faktorjev

\begin{tabular}{lrrr}
\hline Dejavniki & \multicolumn{3}{c}{ Faktor } \\
\cline { 2 - 4 } & 1 & 2 & 3 \\
\hline Ni združljiva & 0,084 & 0,082 & 0,875 \\
Ne nudi vseh funkcionalnosti & 0,055 & 0,115 & 0,844 \\
Ne znam uporabljati & 0,722 & 0,134 & 0,165 \\
Nismo se učili & 0,825 & 0,026 & 0,119 \\
Kolegi uporabljajo K PO & 0,825 & 0,123 & $-0,120$ \\
Ni v domačem jeziku & 0,034 & 0,858 & 0,104 \\
Ni izobraževanj & 0,416 & 0,594 & 0,197 \\
Pomoč ni dostopna v domačem jeziku & 0,072 & 0,879 & 0,026 \\
\hline
\end{tabular}

lja komercialno programsko opremo « imata vrednost faktorskih uteži $(0,825)$, sledi jima spremenljivka »Ne znam je uporabljati v tolikšni meri kot komercialno programsko opremo« $(0,722)$. Glede na vključene spremenljivke in njihovo medsebojno povezanost bomo prvi faktor poimenovali »Nepoznavanje O РО in В РО«.

Pri drugem faktorju imajo visoke faktorske uteži spremenljivke »B P O in O P O nista dostopna v domačem jeziku« $(0,858)$, »Pomoč za uporabo B PO in OPO ni dostopna v domačem jeziku« $(0,879)$ in "Na voljo je manj možnosti izobraževanja za B P O« $(0,594)$. Najvišjo faktorsko utež imata spremenljivki, povezani z jezikovnimi značilnostmi, ki zelo dobro predstavljata vsebino drugega faktorja, s katerim lahko pojasnimo 23,9-odstotni delež celotne variance. Glede na vključene spremenljivke lahko drugi faktor poimenujemo "Jezikovne prepreke«.

Tretji faktor, s katerim pojasnimo 19,8\% celotne variance, ima visoke faktorske uteži pri dveh spremenljivkah. Najvišjo faktorsko utež ima spremenljivka "Ni združljiva s komercialno programsko opremo« $(0,875)$, sledi ji spremenljivka »Ne nudi vseh funkcionalnosti kot komercialna programska oprema « $(0,844)$. Glede na vključene spremenljivke z visokimi faktorskimi utežmi lahko tretji faktor poimenujemo »Pomanjkanje združljivosti in funkcionalnosti O P О in В Р О«.

Na podlagi rezultatov faktorske analize dejavnikov nadomeščanja komercialne programske opreme z OPO in B PO smo ugotovili, da so za anketirance pri odločanju o nadomestitvi komercialne in/ali piratske programske opreme z OPO in B PO pomembni trije dejavniki:

- pomanjkanje znanja pri uporabi O PO in B PO, pri čemer na ta dejavnik najbolj vpliva uporaba komercialnih programov $\mathrm{v}$ okviru 
izobraževalnega procesa ter ozaveščanje uporabnikov o funkcionalnostih OPO in B PO;

- jezikovne prepreke pri uporabi В РО in O Р O, pri čemer gre to dejstvo najverjetneje pripisati tudi nepoznavanju tovrstne programske opreme, ki je v splošnem prevedena v večino svetovnih jezikov;

- pomanjkanje združljivosti B PO in OPO, pri čemer gre najverjetneje spet za nepoznavanje tovrstne programske opreme.

\subsection{Preverjanje hipotez}

$\mathrm{Z}$ raziskavo smo preverili štiri hipoteze, ki se nanašajo na razširjenost piratske programske opreme med študenti. Za preverjanje hipotez smo uporabili korelacijsko analizo, regresijsko analizo in neparametrični Mann-Whitneyjev U-test.

Zaradi omejitve, ki jo predstavlja število študentov posamezne države pri izvedbi raziskave, izsledkov raziskave ne moremo posplošili na celotno študentsko populacijo posamezne države, ampak so izsledki omejeni na preučevani vzorec.

\section{Preizkus hipoteze 1}

H 1 Študentje, ki imajo višjo stopnjo I K T-pismenosti, imajo na računalniku nameščeno večje število piratske programske opreme od tistih z nižjo stopnjo I K T-pismenosti.

Oceno povprečne I K T-pismenosti zajetih enot v vzorcu smo izračunali iz samoocene anketirancev, kot je to prikazano v preglednici 4.3. Povprečna ocena IKT-pismenosti zajetih enot $\mathrm{v}$ vzorcu znaša $\mathrm{M}=3,5$. Vzorec smo nato razdelili na dve skupini (preglednica 4.30). Prvo skupino sestavljajo študentje s podpovprečno stopnjo I K T-pismenosti (M $<3,5$ ). V skupini je 92 enot s povprečno oceno I K T-pismenosti 2,94. V skupini s podpovprečno oceno I K T-pismenosti je povprečna stopnja nameščenosti piratske programske opreme 37,5-odstotna. V drugi skupini študentov, z nadpovprečno stopnjo IK T-pismenosti (M > 3,5), je 108 enot, njihova povprečna ocena I K T-pismenosti je 3,97. Povprečna ocena nameščenosti piratske programske opreme v drugi skupini je $47,4 \%$.

Stopnjo nameščenosti piratske programske opreme smo izračunali iz stopenj nameščenosti posameznih programov (preglednica 4.30).

Preverili smo, ali se povprečna nameščenost piratske programske opreme po skupinah (nadpovprečna in podpovprečna IK T-pismenost) porazdeljuje normalno. Za ugotavljanje predpostavke o normalni po- 
4 Piratstvo programske opreme - raziskava

Preglednica 4.30 Nameščenost piratske programske opreme in I K T-pismenost

\begin{tabular}{llll}
\hline I K T pismenost & Število enot & Povprečje & Standardni odklon \\
\hline$>3,5$ & 108 & 0,47 & 0,26 \\
$<3,5$ & 92 & 0,38 & 0,23 \\
\hline
\end{tabular}

Preglednica 4.31 Rangi po IKT-pismenosti

\begin{tabular}{llll}
\hline I K T pismenost & $N$ & Povprečni rang & Vsota rangov \\
\hline$>3,5$ & 108 & 109,65 & $11.842,00$ \\
$<3,5$ & 92 & 89,76 & $8.258,00$ \\
\hline
\end{tabular}

Preglednica 4.32 Testne statistike

\begin{tabular}{lcll}
\hline Mann-Whitney $U$ & Wilcoxon $W$ & $Z$ & $\begin{array}{l}\text { Stopnja značilno- } \\
\text { sti }^{*}\end{array}$ \\
\hline 3.980,00 & $8.258,00$ & $-2,44$ & 0,015 \\
\hline OP OM B E & ${ }^{*}$ Dvostranska. & &
\end{tabular}

razdelitvi smo na podlagi Kolmogorov-Smirnovega testa in ShapiroWilkovega testa ugotovili, da se spremenljivka "Povprečna nameščenost piratske programske opreme «ne porazdeljuje normalno pri nobeni skupini (Sig. < 0,05). Zaradi kršene predpostavke o normalni porazdelitvi spremenljivke smo $\mathrm{v}$ nadaljevanju za izvedbo raziskave opravili (Mann-Whitneyjev U-test) neparamerični test.

Postavimo ničelno domnevo $\mathrm{Ho}: \mu 1=\mu 2$ in alternativno domnevo $\mathrm{H} 1: \mu 1 \neq \mu 2$, pri čemer $\mu 1$ predstavlja stopnjo nameščenosti piratske programske opreme študentov, ki so nadpovprečno I K T-pismeni, $\mu 2$ pa predstavlja stopnjo nameščenosti piratske programske opreme študentov, ki so podpovprečno IK T-pismeni.

Vrednosti povprečnih rangov (preglednica 4.31) nakazujejo, da imajo nadpovprečno I K T-pismeni višjo stopnjo nameščenosti piratske programske opreme kot podpovprečno I K T-pismeni.

Iz preglednice testnih statistik razberemo (preglednica 4.32), da znaša stopnja značilnosti Sig. = o,015. Glede na dejstvo, da je stopnja značilnosti manjša od o,05, lahko sklepamo, da obstajajo statistično značilne razlike pri uporabi piratske programske opreme med anketiranimi študenti z nadpovprečno I K T-pismenostjo in študenti s podpovprečno I K T-pismenostjo.

$\mathrm{Na}$ podlagi ugotovitev Mann-Whitneyjevega U-testa lahko sprejmemo sklep, da imajo študentje s povprečno višjo stopnjo I K T-pismenosti nameščeno večje število piratske programske opreme od tistih $z$ nižjo I K T-pismenostjo. S tem hipotezo 1 sprejmemo. 
Preglednica 4.33 Rezultati regresijske analize

\begin{tabular}{lrrrrrr}
\hline Postavka & $R$ & $R^{2}$ & Popr. $R^{2}$ & OSN & $F$ & SZ \\
\hline 8 dejavnikov & 0,460 & 0,211 & 0,178 & 0,233 & 6,400 & 0,000 \\
P P O brezplačna & 0,422 & 0,178 & 0,174 & 0,234 & 42,910 & 0,000 \\
K P O predraga & 0,321 & 0,103 & 0,099 & 0,244 & 22,819 & 0,000 \\
Dostopnost na & 0,277 & 0,077 & 0,072 & 0,248 & 16,410 & 0,000 \\
P 2 P & & & & & & \\
\hline
\end{tabular}

OPOMBE OSN - ocena statistične napake, sZ - stopnja značilnosti.

\section{Preizkus hipoteze 2}

H2 Glavni vzrok za razširjenost piratske programske opreme je njena preprosta dostopnost prek omrežij za izmenjavo datotek (P 2 P).

V analizo smo vključili dejavnike, vključene v preglednici 4.16. S pomočjo korelacijske analize smo ugotovili, da več dejavnikov izkazuje pozitivni korelacijski koeficient s spremenljivko »Nameščenost piratske programske opreme«. Spremenljivke, ki izkazujejo pozitivni korelacijski koeficient, smo vključili v regresijsko analizo in ugotovili, da z osmimi dejavniki uspemo pojasniti približno $21 \%$ variabilnosti stopnje nameščenosti piratske programske opreme.

V nadaljevanju smo z regresijsko analizo testirali vpliv treh posameznih dejavnikov, »Piratska programska oprema je brezplačna“, »Komercialna programska oprema je predraga « in "Preprosta dostopnost na omrežjih P 2 P «, na povprečno stopnjo nameščenosti piratske programske opreme (preglednica 4.33). Ugotovili smo, da je regresijski koeficient $R=0,422$ najvišji pri dejavniku »Piratska programska oprema je brezplačna«, determinacijski koeficient $R^{2}=0,178$. Iz navedenega ocenjujemo, da lahko približno $18 \%$ variabilnosti povprečne nameščenosti piratske programske opreme pojasnimo $z$ linearnim vplivom dejavnika cene, "Piratska programska oprema je brezplačna«, preostalih $82 \%$ variabilnosti pa povzročajo drugi $v$ raziskavi navedeni ali nam neznani dejavniki.

Regresijski koeficient dejavnika »Preprosta dostopnost na omrežjih P 2 P « znaša $R=0,277$, determinacijski znaša $R^{2}=0,077$. Na podlagi analize ugotavljamo, da je kazalnik nižji kot pri dejavnikih »Piratska programska oprema je brezplačna« in »Komercialna programska oprema je predraga « (preglednica 4.33), zato ta dejavnik ne predstavlja glavnega razloga za razširjenost piratske programske opreme.

Na podlagi regresijske analize dejavnikov uporabe piratske programske opreme ugotavljamo, da je glavni razlog za uporabo piratske pro- 
4 Piratstvo programske opreme - raziskava

Preglednica 4.34 Nameščenost piratske programske opreme in B D P na prebivalca

\begin{tabular}{llll}
\hline B DP & Število enot & Povprečje & Standardni odklon \\
\hline$>22.706,72$ & 103 & 0,37 & 0,25 \\
$<22.706,72$ & 97 & 0,49 & 0,25 \\
\hline
\end{tabular}

gramske med anketiranimi študenti ta, da jo uporabniki pridobijo brezplačno in da je komercialna programska oprema predraga. Navedeno potrjujejo tudi ugotovitve iz prvega dela monografije. Skladno z navedenim hipoteze 2 ne moremo sprejeti.

\section{Preizkus hipoteze 3}

H3 Obstajajo statistično značilne razlike med stopnjo nameščenosti piratske programske opreme na računalniku študenta posamezne države in razvitostjo države.

Razvitost države smo ugotavljali na podlagi kazalnika BDP za posamezno državo in ugotovili, da posamezne države ustvarjajo različno visok B D P na prebivalca. S pregledom podatkov Svetovne banke smo ugotovili, da je bil v letu 2014 B D P na prebivalca v preučevanih državah različen. ${ }^{16}$ Izračunali smo povprečen $B$ D P na prebivalca za štiri obravnavane države in ta znaša 22.706,72 U S D.

Vzorec smo razdelili na dve skupini (preglednica 4.34), in sicer na skupino študentov iz držav, ki imajo nadpovprečen B D P na prebivalca (Velika Britanija in Slovenija), in na skupino študentov iz držav, ki imajo podpovprečen B D P na prebivalca (Poljska in Srbija).

V skupini z nadpovprečnim B D P na prebivalca, v kateri so zajete 103 statistične enote, znaša povprečna stopnja nameščenosti piratske programske opreme $36,7 \%$. V skupini študentov s podpovprečnim B D P na prebivalca, v kateri je zajetih 97 statističnih enot, znaša povprečna nameščenost piratske programske opreme $49,4 \%$.

Stopnjo nameščenosti piratske programske opreme smo izračunali iz stopenj nameščenosti posameznih programov (preglednica 4.34).

Preverili smo, ali se povprečna nameščenost piratske programske opreme po skupinah porazdeljuje normalno. Za ugotavljanje predpostavke o normalni porazdelitvi smo na podlagi Kolmogorov-Smirnovega

\footnotetext{
${ }^{16}$ V Sloveniji 23.999,13 U S D, v Srbiji 6.152,87 U S D, na Poljskem 14.342,91 U S D in v Veliki Britaniji 46.331,98 USD (glej http://data.worldbank.org/indicator/NY.GDP.PCAP .CD?order=wbapi_data_value_2014\%20wbapi_data_value \%20wbapi_data_value-last \&sort=asc).
} 
Preglednica 4.35 Rangi po B DP na prebivalca

\begin{tabular}{llll}
\hline B D P & $N$ & Povprečni rang & Vsota rangov \\
\hline$>22.706,72$ & 103 & 85,89 & $8.847,00$ \\
$<22.706,72$ & 97 & 116,01 & $11.253,00$ \\
\hline
\end{tabular}

Preglednica 4.36 Testne statistike: stopnja nameščenosti piratske programske opreme

\begin{tabular}{llll}
\hline Mann-Whitney $U$ & Wilcoxon $W$ & $Z$ & Stopnja znač.* \\
\hline 3.491,00 & $8.847,00$ & $-3,70$ & 0,000 \\
\hline
\end{tabular}

OPOMBE * Dvostranska.

testa in Shapiro-Wilkovega testa ugotovili, da se spremenljivka "Povprečna nameščenost piratske programske opreme« ne porazdeljuje normalno pri nobeni skupini (Sig. < 0,05). Zaradi kršene predpostavke o normalni porazdelitvi spremenljivke smo $\mathrm{v}$ nadaljevanju za izvedbo raziskave opravili neparamerični test (Mann-Whitneyjev U-test).

Postavimo ničelno domnevo $\mathrm{Ho}: \mu_{1}=\mu_{2}$ in alternativno domnevo H1: $\mu 1 \neq \mu 2$, pri čemer $\mu 1$ predstavlja stopnjo nameščenosti piratske programske opreme študentov $\mathrm{v}$ državah $\mathrm{z}$ nadpovprečnim B D P na prebivalca (Velika Britanija, Slovenija), $\mu 2$ pa stopnjo nameščenosti piratske programske opreme študentov $\mathrm{v}$ državah s podpovprečnim B DP na prebivalca (Poljska, Srbija).

Vrednosti povprečnih rangov (preglednica 4.35) nakazujejo, da imajo študentje iz držav $z$ nadpovprečnim B DP na prebivalca nižjo stopnjo nameščenosti piratske programske opreme od študentov iz držav s podpovprečnim BDP na prebivalca.

Iz preglednice testnih statistik (preglednica 4.36) razberemo, da znaša stopnja značilnosti Sig. $=0,000$.

Na podlagi ugotovitev Mann-Whitneyjevega U-testa ugotavljamo, da je stopnja značilnosti manjša od 0,05 , zato lahko z zadostno stopnjo verjetnosti sklepamo, da obstajajo statistično značilne razlike pri uporabi piratske programske opreme med anketiranimi študenti iz držav z nadpovprečnim B D P na prebivalca in anketiranimi študenti iz držav s podpovprečnim B D P na prebivalca. Iz navedenih razlogov hipotezo 3 sprejmemo.

\section{Preizkus hipoteze 4}

$\mathrm{H} 4$ Strožja zakonodaja na področju piratstva programske opreme bi zmanjšala stopnjo uporabe piratske programske opreme. 
4 Piratstvo programske opreme - raziskava

Preglednica 4.37 Korelacijska matrika

\begin{tabular}{ll}
\hline Spremenljivka & Povprečna stopnja nameščenosti piratske programske opreme \\
\hline Strožja zakonodaja & $-0,23^{* *}$ \\
\hline OP OM B E & ${ }^{* *}$ Statistično značilna korelacija pri $p=0,01$.
\end{tabular}

S Spearmanovim koeficientom korelacije smo merili moč in smer linearne povezanosti med spremenljivkama, za kateri smo na podlagi Kolmogorov-Smirnovega testa in Shapiro-Wilkovega testa ugotovili, da nista normalno porazdeljeni.

Ugotovili smo, da obstaja šibka, obratno sorazmerna povezanost med spremenljivkama, ki je statistično značilna (preglednica 4.37). Iz tega sklepamo, da strožja zakonodaja vpliva na znižanje stopnje nameščenosti piratske programske opreme v raziskavi zajetih študentov. $\mathrm{Na}$ podlagi korelacijske analize hipotezo 4 sprejmemo. 


\section{Sklep}

V monografiji smo obravnavali razširjenost piratske programske opreme med študenti Slovenije, Srbije, Poljske in Velike Britanije. V teoretičnem delu smo tozadevno obravnavali zakonodajo, ki se nanaša na kršenje avtorskih pravic $\mathrm{v}$ povezavi $\mathrm{z}$ računalniškimi programi $\mathrm{v}$ obravnavanih državah. Ugotovili smo, da se v posameznih državah zakonodaja bistveno ne razlikuje, saj temelji na enakih pravnih temeljih, in sicer na Bernski konvenciji in Direktivi 91/250/E G S, na podlagi katere so države harmonizirale zakonodajo v okviru Evropske skupnosti. Tudi Srbija je v okviru pristopnih pogajanj harmonizirala zakonodajo na področju avtorskih pravic, pri čemer smo ugotovili, da pristojne službe ne izvršujejo ukrepov za preprečevanje piratstva $\mathrm{v}$ zadostni meri.

V teoretičnem delu smo opredelili vrste piratstva, pri čemer smo ugotovili, da je najpomembnejša vrsta internetno piratstvo. V okviru internetnega piratstva programske opreme smo analizirali vrste omrežij, prek katerih se piratske vsebine najpogosteje prenašajo na osebne računalnike uporabnikov piratske programske opreme. Opredelili smo tudi dejavnike, ki vplivajo na povpraševanje in ponudbo po piratski programski opremi.

Ugotovili smo, da v okviru možnosti za zmanjšanje piratstva programske opreme obstajajo tri vrste ukrepov. Prva so ukrepi industrije, ki se izvršujejo prek ozaveščanja uporabnikov o škodljivih posledicah piratstva in uvedbe tehnične zaščite, ki onemogoča reprodukcijo in distribucijo piratske programske opreme. Kot drugo vrsto ukrepov smo opredelili vlogo države in sprejemanje zakonodaje na področju kršenja avtorskih ter sorodnih pravic. Tretji ukrep oziroma dejavnik, ki bi lahko zmanjšal uporabo piratske programske opreme, smo opredelili kot ponudbo brezplačne in odprtokodne programske opreme, ki v večini primerov predstavlja ustrezne brezplačne nadomestke piratski programski opremi.

V drugem delu monografije prikazujemo rezultate raziskave, ki smo jo izvedli med slovenskimi, srbskimi, poljskimi in britanskimi študenti. 
Na podlagi prejetih odgovorov študentov obravnavanih držav smo izvedli kvantitativno raziskavo na vzorcu 200 popolnoma izpolnjenih anketnih vprašalnikov. Stratificiran vzorec smo oblikovali na osnovi razmerij med izračunanimi deleži študentov v celotni populaciji preučevanje države.

Anketiranci so stopnjo svoje IK T-pismenosti na petstopenjski lestvici ocenili s povprečno oceno 3,5. Najvišjo oceno so anketiranci podali za splošna opravila v okolju operacijskega sistema Windows, ki so jim v povprečju dodelili oceno 4,7 , kot svojo najslabše razvito I K T-veščino pa so ocenili programiranje $\mathrm{v}$ računalniškem programskem jeziku $(1,7)$.

Anketiranci so se opredelili tudi do nameščenosti programske opreme na svojih računalnikih. Ugotovili smo, da največji delež nameščene piratske programske opreme pripada pisarniškim paketom. Raziskava je pokazala, da glede na spol ne moremo potrditi obstoja statistično značilnih razlik v stopnji nameščenosti piratske programske opreme. Statistično značilne razlike smo zaznali glede na stopnjo študijskega programa. Rezultati Kruskal-Wallisovega testa so pokazali, da obstajajo statistično značilne razlike glede stopnje nameščenosti piratske programske opreme tudi glede na državo prebivanja študenta. $Z$ dodatnimi analizami smo za slovenske študente ugotovili, da se njihova stopnja nameščenosti statistično značilno razlikuje od britanskih in srbskih študentov, ne moremo pa potrditi, da se statistično značilno razlikuje od poljskih.

$\mathrm{Z}$ multiplo regresijsko analizo smo $\mathrm{v}$ nadaljevanju ugotavljali odvisnost stopnje nameščenosti piratske programske opreme od tehnoloških dejavnikov. V to skupino smo umestili spremenljivke "IKTpismenost študentov«, »Prenos P 2 P«, »Prenos odjemalec - strežnik« in "Vir namestitve piratske programske opreme«. Ugotovili smo, da $32 \%$ variance odvisne spremenljivke (nameščenosti piratske programske opreme) lahko pojasnimo $\mathrm{z}$ linearnim vplivom tehnoloških dejavnikov, preostalih $68 \%$ pa povzročajo neznani ali naključni dejavniki.

Raziskali smo tudi dejavnike, ki vplivajo na odločitev posameznika za uporabo piratske programske opreme ali pa ga od uporabe odvračajo. $Z$ namenom zmanjšanja števila dejavnikov smo izvedli faktorsko analizo in ugotovili, da 71,7\% variabilnosti pojava lahko pojasnimo s tremi dejavniki. Poimenovali smo jih »Tveganje kaznovanosti«, »Cena in preprostost operacij« ter »Moralni razlogi, ozaveščenost in avtorjeva oddaljenost«.

S Kruskal-Wallisovim testom smo v nadaljevanju preverili, ali glede 
Preglednica 5.1 Obravnavane hipoteze

1 Študentje, ki imajo višjo stopnjo I K T-pismenosti, imajo na računal- Sprejeta niku nameščeno večje število piratske programske opreme od tistih z nižjo stopnjo I K T-pismenosti.

2 Glavni razlog za razširjenost piratske programske opreme je njena Zavrnjena enostavna dostopnost preko omrežij za izmenjavo datotek (P 2 P).

3 Obstajajo statistično značilne razlike med stopnjo nameščenosti pi- Sprejeta ratske programske opreme na računalniku študenta posamezne $\mathrm{dr}-$ žave in razvitostjo države.

4 Strožja zakonodaja na področju piratstva programske opreme bi Sprejeta zmanjšala stopnjo uporabe piratske programske opreme.

na državo prebivanja študentov obstajajo statistično značilne razlike med dejavniki, ki vplivajo na uporabo piratske programske opreme. Ugotovili smo, da statistično značilnih razlik med dejavniki po državah ne moremo potrditi.

V raziskavo smo vključili tudi vprašanja glede možnosti nadomestitve komercialne ali piratske programske opreme $z$ ustreznim в PO ali O P O. Anketiranci so v naboru programov za nadomeščanje komercialne programske opreme najvišje ocenili internetne brskalnike in programe za stiskanje datotek. Raziskati smo želeli tudi dejavnike, zaradi katerih študentje ne posegajo po ОРО in В РО. Izvedli smo faktorsko analizo in opredelili tri dejavnike, na podlagi katerih pojasnimo $69,6 \%$ variabilnosti pojava. Poimenovali smo jih »Nepoznavanje O P O in B P O«, »Jezikovne prepreke« ter »Pomanjkanje združljivosti in funkcionalnosti O P O in ВРО«.

$Z$ raziskavo smo preverjali veljavnost štirih hipotez (preglednica 5.1). $\mathrm{V}$ prvi hipotezi smo predpostavljali, da imajo študentje $\mathrm{z}$ višjo stopnjo IKT-pismenosti na svojih računalnikih nameščene več piratske programske opreme. Anketirane smo razdelili v dve skupini, na IKTnadpovprečno pismene in I K T-podpovprečno pismene. Z Mann-Whitneyjevim U-testom smo testirali enakost variance med obema vzorcema in ugotovili, da obstajajo statistično značilne razlike v stopnji nameščenosti piratske programske opreme med obema skupinama. Hipotezo 1 smo zato potrdili.

V okviru druge hipoteze smo predpostavili, da je glavni razlog za razširjenost piratske programske opreme njena preprosta dostopnost prek omrežij P 2 P. S korelacijsko in z regresijsko analizo posameznih dejavnikov smo ugotovili, da preprosta dostopnost prek omrežij P 2 P ni glavni 
dejavnik razširjenosti piratske programske opreme, zato hipoteze 2 nismo mogli potrditi.

V tretji hipotezi smo predpostavljali, da obstajajo statistično značilne razlike med nameščenostjo piratske programske opreme na računalniku študenta posamezne države in razvitostjo države. Razvitost države smo opredelili v okviru kazalnika B D P na prebivalca, ki je v preučevanih državah različen. Države smo razdelili v dve skupini: na tiste $\mathrm{z}$ nadpovprečnim B D P na prebivalca in tiste s podpovprečnim B D P na prebivalca. Na podlagi Mann-Whitneyjevega U-testa smo ugotovili, da obstajajo statistično značilne razlike $\mathrm{v}$ nameščenosti piratske programske opreme med študenti iz držav z nadpovprečnim B D P na prebivalca in tistimi iz držav s podpovprečnim B D P na prebivalca.

Četrta hipoteza je predpostavljala, da bi ostrejša zakonodaja na področju piratstva programske opreme zmanjšala stopnjo piratske progamske opreme. Korelacijski koeficient med spremenljivkama »Strožja zakonodaja« in »Nameščenost piratske programske opreme« znaša -0,23. Iz tega smo izpeljali sklep, da bi ostrejša zakonodaja vplivala na zmanjšanje stopnje nameščenosti piratske programske opreme, zato smo hipotezo 4 sprejeli.

V monografiji smo preučevali razširjenost piratske programske opreme na osebnih računalnikih. $Z$ razvojem I $\mathrm{T}$ se razvoj strojne opreme in uporaba programske opreme selita tudi na druga področja. Mobilna telefonija in razvoj aplikacij vsekakor zahtevata specifično obravnavo $\mathrm{v}$ okviru preučevanja piratstva programske opreme glede načina pridobivanja in namestitve programske opreme, zaradi česar bi bilo raziskavo smiselno ponoviti tudi na tem področju.

Piratstvo programske opreme ni vezano le na študentsko populacijo, zato bi bilo $\mathrm{v}$ prihodnje smiselno raziskavo ponoviti med preostalimi populacijami in ustanovami.

Rezultati raziskave bodo $v$ pomoč izobraževalnim ustanovam za ozaveščanje študentov glede kršenja avtorskih pravic na področju programske opreme in drugih piratskih vsebin ter pri uvajanju uporabe brezplačnih nadomestkov komercialne programske opreme. 


\section{Literatura}

Albanese, Jay S. 2011. Combating Piracy: Intellectual Property Theft and Fraud. New Brunswick: Transaction Publishers.

Agarwal, Adarsh, Nipun Bansal in Sudeep Gupta. 2013. »Peer to Peer Networking and Applications. «International Journal of Advanced Research in Computer Science and Software Engineering 3 (8): 578-586.

Arnold, Michael, Eric Darmon, Sylvain Dejean in Thierry Penard. 2014. "Graduated Response Policy and the Behavior of Digital Pirates: Evidence from the French Three-Strike (Hadopi) Law. «Working Papers 14-07, University of Delaware, Newark, DE.

Backx, Peter, Tim Wauters, Bart Dhoedt in Piet Demeester. 2002. »A Comparison of Peer-to-Peer Architectures."V Proceedings of the Eurescom Summit 2002 Powerful Networks for Profitable Services, 215-222. Berlin: VDE.

Biddle, Peter, Paul England, Marcus Peinado in Bryan Willman. 2002. "The Darknet and the Future of Content Distribution. «V DRM 2002: Digital Rights Management, ur. Joan Feigenbaum, 155-176. Lecture Notes in Computer Science 2696. Berlin: Springer.

Bizjak, Emil. 2012. »Dejavniki uporabe odprtokodne programske opreme v slovenskih podjetjih.« Magistrsko delo, Univerza na Primorskem, Koper.

B S A. 2014. The Compliance Gap: BSA Global Software Survey. Washington, D C: BSA.

Bogataj Jančič, Maja. 2008. Avtorsko pravo v digitalni dobi: problematika zaščite avtorskih del s tehnološkimi ukrepi. Ljubljana: Pasadena.

Breznik Močnik, Marija, Maja Bogataj Jančič, Matej Kovačič in Aldo Milohnić. 2008. Upravljanje avtorskih in sorodnih pravic v digitalnem okolju. Ljubljana: A R R S in Urad Republike Slovenije za intelektualno lastnino.

Buford, John, Heather Yu in Eng Keong Lua. 2009. P 2 P Networking and Applications. Burlington, MA: Morgan Kaufmann.

Butt, Adeel I., Arsalan Butt in Simon Fraser. 2007. „Software Piracy Determinants Among University Students: An Empirical Analysis.« V Managing Worldwide Operations and Communications with Information Technology, ur. Mehdi Khosrow-Pour, 474-478. Hershey, PA: I RM A.

Castro, Daniel, Richard Bennet in Scott Andes. 2009. "Steal These Policies: Strategies for Reducing Digital Piracy.« I I I F, Washington, DC. 
Chaudhry, Peggy E., Sohail S. Chaudhry, Stephen A. Stumpf in Hasshi Sudler. 2010. "Piracy in Cyber Space: Consumer Complicity, Pirates and Enterprise Enforcement.« Enterprise Information Systems 5 (2): 255-271.

Craig, Paul, Ron Honick in Mark Brunett. 2005. Software Piracy Exposed. Rockland, M A: Syngress.

Cronan, Timothy Paul in Sulaiman Al Rafee. 2008. „Factors that Influence the Intention to Pirate Software and Media." Journal of Business Ethics 78:527-545.

Cvitkovič, Dejan. 2004. "Poslovni modeli v omrežjih enakovrednih računalnikov.« Magistrsko delo, Univerza v Ljubljani, Ljubljana.

Dahlstrom Dana, Nathan Farrington, Daniel Gobera, Ryan Roemer in Nabil Schear. 2006. "Piracy in the Digital Age. "Seminarska naloga, University of California, San Diego.

Digital Citizens Alliance. 2014. »Good Money Gone Bad; Digital Thieves and the Hijacking of the Online Ad Business; A Report on the Profitability of Ad-Supported Content Theft.«http://media.digitalcitizensactionalliance .org/314 $\mathrm{A}_{5} \mathrm{~A}_{5} \mathrm{~A}_{9} \mathrm{ABBBBC} \mathrm{E}_{3} \mathrm{BD} 8{ }_{24} \mathrm{CF}_{47} \mathrm{C}_{4} 6 \mathrm{EF}_{4} \mathrm{~B}_{9} \mathrm{D}_{3} \mathrm{~A}_{76} / 4 \mathrm{af}_{7} \mathrm{db} 7 \mathrm{f}-\mathrm{o}_{3} \mathrm{e}$ -49cb-aeb8-ado671a4e1c7.pdf

U S Department of State. 2015. "Serbia Investment Climate Statement 2015." Http://www.state.gov/documents/organization/241942.pdf

European Commision. 2014. »Serbia Progress Report.« http://ec.europa.eu/ enlargement/pdf/key_documents/2014/20140108-serbia-progress -report_en.pdf

Ferligoj, Anuška. 2003. »Faktorska analiza.« http://vlado.fmf.uni-lj.si/vlado/ podstat/Mva/FA.pdf

Fogel, Karl. 2015. Producing Open Source Software: How to Run a Successful Free Software Project. Sebastopol, c A: O’Reilly Media.

Fuchs, Julian. 2015. "A Torrent Recomender Based on D H T Crawling.« Diplomska naloga, Swiss Federal Institute of Technology, Zürich. ftp://ftp.tik .ee.ethz.ch/pub/students/2014-HS/BA-2014-15.pdf

Gramstad, Arne Rogde. 2014. "Piracy in Commercial vs. Open-Source Software: Competition.«http://www.sv.uio.no/econ/english/research/news -and-events/events/conferences/2014/papers/gramstad_norio21april .pdf

Hars, Alexander in Shaosong Ou. 2002. „Working for Free? Motivations of Participating in Open Source Projects. " Journal International Journal of Electronic Commerce 6 (3): 25-39.

Hill, Charles W. L. 2007. "Digital Piracy: Causes, Consequences, and Strategic Responses. "Asia Pacific Journal of Management 24 (1): 9-25.

Hsu, Jane L., in Charlene W. Shiue. 2008. „Consumers' Willingness to Pay for Non-Pirated Software.« Journal of Business Ethics 81 (4): 715-732. 
Informacijski pooblaščenec. 2009. "Socialni inženiring in kako se pred njim ubraniti?« https://www.ip-rs.si/fileadmin/user_upload/Pdf/smernice/ socialni-inzeniring-in-kako-se-pred-njim-ubraniti.pdf

Intellectual Property Office. 2014. "Intellectual Property Crime and Infringement.«https://www.gov.uk/guidance/intellectual-property-crime -and-infringement\#annual-ip-crime-report

International Intellectual Property Alliance. 2011. »Poland: 2011 Special 301 Report on Copyright Protection and Enforcement.«http://www.iipa.com $/ \mathrm{rbc} / 2011 / 2011$ SPEC301POLAND.pdf

ISlovar. 2016. Ljubljana: Slovensko društvo Informatika. http://www.islovar .org

Jaafar, Mastura, Thurasamy Ramayah in Tee Wan Teng. 2008. »The Intention to Use Pirated Software: A Study of Undergraduate Students in a Public Institution of Higher Learning in Malaysia."Problems and Perspectives in Management 6 (2). https://businessperspectives.org/media/zoo/ applications/publishing/templates/article/assets/js/pdfjs/web/2157

Kalezić, Biljana. 2010. "Software Piracy in Serbia.«INF Otheca 9 (1): 39a-51a.

Karakaya, Musa in Bülent Ulutürk. 2011. »Individual and Social Reasons behind Software Piracy: An Analysis of Previous Studies.«International Journal of Security and Terrorism 2 (2): 59-72.

Khomh, Foutse, Tejinder Dhaliwal, Ying Zou in Bram Adams. 2012. „Do Faster Releases Improve Software Quality? An Empirical Case Study of Mozilla Firefox.«http://mcis.soccerlab.polymtl.ca/publications/2012/ MSR2012Foutse.pdf

Khong, Denis W. K. 2006. „The Historical Law and Economics of the First Copyright Act." Erasmus Law and Economics Review 2 (1): 35-69.

Kizza, Joseph Migga. 2013. Ethical and Social Issues in the Information Age. 3. izd. London: Springer Science \& Business Media.

Klumpp, Tilman. 2013. »File Sharing, Network Architecture, and Copyright Enforcement: An Overview.« https://www.ualberta.ca/ klumpp/docs/ filesharing.pdf

Kovačič, Matej, Alenka Žvabi, Tomi Dolenc, Gorazd Božič, Tia Zupančič, Tanja Šterk in Ajda Jerman Kuželički. 2009. Deskanje po varnih vodah. Ljubljana: Fakulteta za družbene vede.

Krawczyk, Michał, Joanna Tyrowicz, Anna Kukla-Gryz in Wojciech Hardy. 2014. "Piracy is Not Theft! It Is Just Students Who Think So? « Journal of Behavioral and Experimental Economics 54:32-39.

Lalović, Gordana. 2009. »Model nakupnega odločanja porabnikov pri kraji intelektualne lastnine: primer srbskega trga.« Magistrsko delo, Univerza v Ljubljani, Ljubljana. 
Lancaster, Geoff. 2004. Excel HSC Software Design and Development. Glebe: Pascal Press.

Lau, Eric Kin Wai. 2003. "An Empirical Study of Software Piracy.« Business Ethics: A European Review 12 (3): 233-245.

Lerner, Josh in Jean Tirole. 2002. "Some Simple Economics of Open Source." The Journal of Industrial Economics 50:197-234.

Liao, Checen, Hong Nan Lin in Yu Ping Liu. 2010. »Predicting the Use of Pirated Software: A Contingency Model Integrating Perceived Risk with the Theory of Planned Behavior.« Journal of Business Ethics 91:237-252.

Libreoffice. 2014. "2014 Annual Report.« https://wiki.documentfoundation .org/images/4/47/TDF2014AnnualReport.pdf

Logsdon, Jeanne M., Judith Kenner Thompson in Richard A. Reid. 1994. „Software Piracy: Is It Related to Level of Moral Judgement?« http://beta .orionsshoulders.com/Resources/articles/26_22265_\%20().pdf

Lucchi, Nicola. 2011. "Regulation and Control of Communication: The French Online Copyright Infringement Law (H A D O P I).« Research Paper 11-07, Max Planck Institute for Intellectual Property \& Competition Law, Munich.

Malhotra, Yogesh. 1994. „Controlling Copyright Infringements of Intellectual Property: The Case of Computer Software - Part Two.« Journal of Systems Management, junij, 45-50.

Maly, Robin Jan. 2003. »Comparison of Centralized (Client-Server) and Decentralized (Peer-to-Peer) Networking." Semestrska naloga, Swiss Federal Institute of Technology, Zürich. ftp://ftp.tik.ee.ethz.ch/pub/students/ 2002-2003-Wi/SA-2003-16.pdf

Marshal, Amy. 2006. „Causes, Effects and Solutions of Piracy in the Computer Software Market." Review of Economic Research on Copyright Issues 4 (1): 63-86.

McCoy, Damon, Kevin Bauer, Dirk Grunwald, Tadayoshi Kohno in Douglas Sicker. 2008. "Shining Light in Dark Places: Understanding the Tor Network. "Lecture Notes in Computer Science 5134:63-76.

Milić, Dimitrije. 2011. Komentar Zakona o autorskom i srodnim pravima. Beograd: N NK international.

Moores, Trevor, in Grupert Dhillon. 2000. »Software Piracy: A View from Hong Kong." Communications of the ACM 43 (12): 88-93.

Moores, Trevor T., in Vatcharaporn Esichaikul. 2011. „Socialization and Software Piracy: A Study.«http://beta.orionsshoulders.com/Resources/ articles/26_22269_\%20\%28\%29.pdf

Morgan, Lorraine, in Patrick Finnegan. 2007. »Benefits and Drawbacks of Open Source Software: An Exploratory Study of Secondary Software Firms."In Open Source Development, Adoption and Innovation: OS S 2007, 
307-312. The International Federation for Information Processing 234. Boston, M A: Springer.

Nema, Mudit. 2014. »Intellectual Property Crimes with Special References to Software Piracy.«http://ssrn.com/abstract $=2398008$

Novos, Ian E., in Michael Waldman. 2013. "Piracy of Intellectual Property: Past, Present, and Future." Review of Economic Research on Copyright Issues 10 (2): 1-26.

Ovčak Kos, Maja. 2015. Pogodbena svoboda v avtorskem pravu. Ljubljana: I U S Software in GV založba.

Pankaja, N., in Mukund P. K. Raj. 2013. »Proprietary Software versus Open Source Software for Education. «American Journal of Engineering Research 2 (7): 124-130.

Pavčnik, Marijan. 2015. Teorija prava: prispevek $k$ razumevanju prava. 5. izd. Ljubljana: I U S Software in GV založba.

Peukert, Christian, Jörg Claussen in Tobias Kretschmer. 2015. "Piracy and Box Office Movie Revenues: Evidence from Megaupload.«International Journal of Industrial Organization 52: 188-215.

Phau, Ian, in James Ng. 2010. "Predictors of Usage Intentions of Pirated Software. "Journal of Business Ethics 94:23-37.

Raghu, T. S., Fernando Machado in Rajiv K. Shina. 2014. "Software Piracy in the Presence of Open Source Alternatives.« http://ssrn.com/abstract $=2579355$

Rey, S. Y. 2008. »Show Me the Code: Spatial Analysis and Open Source. « Journal of Geographical Systems 11 (2): 191-207.

Rychlicki, Tomasz, ur. 2011. "Introduction to Software Protection under Polish Law."V The International Free and Open Source Software Law Book. http://ifosslawbook.org/poland/

Samuelson, Paul A., in William D. Nordhaus. 1992. Economics. 14. izd. New York: McGraw-Hill.

Siegfried, Robert M. 2004. "Student Attitudes on Software Piracy and Related Issues of Computer Ethics.« http://home.adelphi.edu/ siegfried/ ETIN2004.pdf

Simić, Stefan. 2015. "Sudska zaštita prava intelektualne svojine u Republici Srbiji.« Pravo: teorija i praksa 32 (1-3): 47-6o.

Slusarek, Maciej. 2003. »Protecting Intellectual Property in Poland."Paper presented at the Euro-Link for Lawyers Conference, Firence, 17. oktober. Https://web.archive.org/web/20080509075307/Http://www.worldlinklaw.com/pdf/intellectual_property_poland.pdf

Spark, Linda. 2010. »The Demographic Factors Affecting University Students' Intention to Pirate Software.« http://opendl.ifip-tc6.org/db/conf/hcc/ hcc2010/Spark10.pdf 
Statistical Office of the Republic of Serbia. 2014. Statistical Yearbook of the Republic of Serbia 2014. Beograd: Statistical Office of the Republic of Serbia. http://pod2.stat.gov .rs/ObjavljenePublikacije/God/SGS2014.pdf

Stryszowski, Piotr, in Danny Scorpecci. 2009. Piracy of Digital Content. Pariz: OECD.

Šušter Erjavec, Hana, in Laura Južnik Rotar. 2013. Analiza podatkov s SP S S. 2. izdaja, Celje: Fakulteta za komercialne in poslovne vede.

Tan, Benjamin. 2002. »Understanding Consumer Ethical Decision Making with Respect to Purchase of Pirated Software.« Journal of Consumer Marketing 19 (2): 96-111.

Tržni inšpektorat Republike Slovenije. 2014. "Nadzor spoštovanja avtorskih pravic na računalniškem področju.«http://www.ti.gov.si/si/storitve/s _cim_se_ukvarjamo/aktualna_porocila/2014_01_20_avtorske_pravic _na_racunalniskem_podrocju/

Van der Sar, Ernesto. 2016. „Top 10 Most Popular Torrent Sites of 2015." TorrentFreak, 4. januar. Https://torrentfreak.com/top-popular-torrentsites-2015-150104/

Veitch, Robert W. D., in Ioanna Constantiou. 2011. »To Pirate or Purchase? A Model of Individual Decisions for Digital Product Acquisition.« http:// aisel.aisnet.org/mcis2011/54

Vuga, Tanja. 2015. Kako zavarovati industrijsko lastnino: uveljavljanje pravic industrijske lastnine pred sodiščem. Ljubljana: I U S Software in GV založba.

Wang, Xiao, in Steven R. McClung. 2011. »The Immorality of Illegal Downloading: The Role of Anticipated Guilt and General Emotions." Computers in Human Behavior 28:153-159.

World Intellectual Property Organization. 1996. „WI P O Copyright Treaty.« http://www.wipo.int/treaties/en/text.jsp?file_id=295166

World Intellectual Property Organization. 2004. WI PO Guide on the Licensing of Copyright and Related Rights. Ženeva: World Intellectual Property Organization. http://www.wipo.int/edocs/pubdocs/en/copyright/897/wipo _pub_897.pdf

Yang, Beverly, in Hector Garcia-Molina. 2001. "Comparing Hybrid Peer-toPeer Systems. "Predstavljeno na 27th V L D B Conference, Rim, 11-14 maj. http://ilpubs.stanford.edu:809o/727/1/2001-36.pdf

Zgaga, Sabina. 2011. "Kaznivost nezakonitega prenašanja avtorskih del prek interneta po novem.« Pravna praksa 30 (46): 11-12. 


\section{Priloge}

\section{Priloga 1: Anketni vprašalnik}

I. Veščine IKT in vir pridobitve programske opreme

1. Ocenite svoje veščine pri uporabi računalnika (na vrednostni lestvici od 1 do 5 pri vsakem odgovoru označite svoje veščine, pri čemer 1 pomeni, da teh veščin sploh nimate, 5 pa pomeni, da imate te veščine popolnoma razvite).

- Splošna opravila v okolju operacijskega sistema (kopiranje, lepljenje, brisanje, ustvarjanje datotek, poimenovanje datotek)

- Uporaba osnovnih matematičnih operacij (seštevanje, odštevanje, deljenje in množenje) v programih za delo s preglednicami (npr. Excel)

- Uporaba programov za stiskanje (kompresiranje) podatkov (Winzip, Winrar, 7zip itn.)

- Uporaba programov za pripravo predstavitev (npr. PowerPoint), z vključitvijo slik, videa, animacij, grafikonov itn.

- Priklop računalnika v mrežo in upravljanje z mrežo več računalnikov

- Uporaba programov za zaščito računalnika pred virusi in zaščito podatkov

- Programiranje v računalniškem programskem jeziku

2. Kje in kako ste pridobili (kupili) programsko opremo (vedno, pogosto, včasih, redko, nikoli)?

- Kupil sem jo v trgovini z računalniško opremo.

- Zakonito sem jo kupil in prenesel z interneta.

- Kupil sem računalnik z že nameščeno licenčno programsko opremo.

- Prenesel sem jo s pomočjo programov za izmenjavo datotek P2P (torrent, eMule itn.)

- Prenesel sem jo neposredno z interneta, s spletnih strani s piratsko vsebino.

- Kupil sem že računalnik z že nameščeno piratsko programsko opremo.

- Kupil sem medij (CD, DVD) s piratsko programsko opremo.

- Programsko opremo sem kupil in jo namestil na več računalnikov, kot to dovoljuje licenca. 
II. Uporaba piratske programske opreme

3. Prosimo vas, da na vrednostni lestvici od 1 do 5 označite svoje strinjanje $\mathrm{s}$ trditvijo (pri čemer ocena 1 pomeni sploh se ne strinjam, ocena $5 \mathrm{pa}$ pomeni popolnoma se strinjam).

- Piratsko programsko opremo uporabljam, ker je brezplačna.

- Piratsko opremo uporabljam, ker je komercialna programska oprema predraga.

- Piratska programska oprema je enake kakovosti kot tista, ki jo kupimo.

- Pravico imam do uporabe piratske programske opreme, saj sem jo prosto prenesel $\mathrm{z}$ interneta.

- Z uporabo piratske programske opreme ne povzročam škode nikomur.

- Piratsko programsko opremo uporabljam, ker je preprosto dostopna prek omrežij P 2 P.

- Bojim se, da bi ob prenosu piratskih vsebin z interneta prejel računalniške viruse in jih tudi namestil.

- V dozdajšnjem izobraževalnem procesu smo vedno uporabljali komercialno programsko opremo (Windows, Office itn.).

- Dozdajšnji izobraževalni proces mi je dal dovolj veščin in znanj za uporabo brezplačne (odprtokodne) programske opreme.

- Piratski programi na internetu so javni in jih smem uporabljati.

- Zavedam se protizakonitosti uporabe piratske programske opreme.

- Bojim se, da bodo organi pregona odkrili moje prenose in uporabo piratske programske opreme.

4. Kdo vam je piratsko programsko opremo namestil na računalnik, ki ga uporabljate?

- Sam sem si jo namestil

- Sorodnik, prijatelj oz. znanec

- Računalniški strokovnjak

- Prodajalec (zaposleni) v trgovini z računalniško opremo

- Drugo

5. Če imate na katerem izmed računalnikov, ki ga uporabljate, nameščeno piratsko programsko opremo, vas prosimo, da odgovorite, katero piratsko programsko opremo imate nameščeno po vašem najboljšem vedenju (da, ne, ne vem).

- Operacijski sistem (Microsoft Windows)

- Pisarniški paket (npr. Microsoft Office)

- Protivirusni program (NOD32, Kaspersky, Norton AV itn.)

- Programi za obdelovanje fotografij (npr. Photoshop) 
- Programe za CAD-oblikovanje (npr. Auto CAD)

- Programe za snemanje CD/DVD (npr. Nero burning room, CloneCD)

- Programe za predvajanje multimedijskih vsebin (npr. Windows media player, WinX DVD player)

- Program za stiskanje (kompresiranje) datotek (Win Zip, Winrar itn.)

- Programe za prevajanje (slovarji)

- Druge vrste programske opreme

6. Kateri ukrepi ali dejavniki bi bistveno pripomogli k zmanjševanju stopnje piratstva programske opreme (ocena 1 pomeni, da sploh ne bi pripomogli, ocena 5 pa pomeni, da bi zelo pripomogli k zmanjšanju)?

- Nižje cene komercialne programske opreme

- Uvedba tehnične zaščite proti kopiranju programske opreme

- Strožja zakonodaja na področju uporabe piratske programske opreme

- Višje sankcije (kazni) za uporabo piratske programske opreme

- Uvedba nadzora uporabe interneta od ponudnikov internetnega dostopa

- Omejitev hitrosti prenosa internetnih podatkov ob ugotovljenih zlorabah prenosa piratskih vsebin

- Aktivacija programske opreme neposredno na strežnikih proizvajalca programske opreme

III. Uporaba brezplačne in/ali odprtokodne programske opreme

7. Ali imate na računalniku, ki ga uporabljate, nameščeno brezplačno (odprtokodno) programsko opremo (da, ne)?

8. Ali menite, da lahko brezplačna (odprtokodna) programska oprema popolnoma nadomesti komercialno ali piratsko programsko opremo (da, ne)?

9. Ocenite od 1 do 5, v kolikšni meri lahko brezplačna (odprtokodna) programska oprema nadomesti komercialno programsko opremo (pri čemer ocena 1 pomeni, da brezplačna programska oprema sploh ne more nadomestiti komercialne, ocena 5 pa pomeni, da brezplačna programska oprema popolnoma nadomesti komercialno).

- Unix (Linux, Ubuntu) : Windows

- LibreOffice : Microsoft Office.

- Antivirus Avira, Avast, AVG : NOD32, Norton, Kaspersky

- Firefox, Chrome : Internet Explorer

- Thunderbird : Outlook Express

- Gimp, Paint.net : Photoshop

- CD burnerXP, IMG burn : Nero burning room

- VLC player : Windows media player 
- 7 Zip : Win Zip, Win RA R

10. Označite strinjanje s trditvami, zakaj odprtokodna (brezplačna) programska oprema ne more nadomestiti komercialne programske opreme (pri čemer ocena 1 pomeni sploh se ne strinjam, ocena 5 pa pomeni popolnoma se strinjam).

- Ker ni združljiva s komercialno programsko opremo.

- Ker ne nudi vseh funkcionalnosti kot komercialna programska oprema.

- Ne znam je uporabljati tako kot komercialne programske opreme.

- Ker smo se v šoli učili uporabljati izključno komercialno programsko opremo.

- Ker večina mojih kolegov uporablja komercialno programsko opremo.

- Ker ne zagotavlja enake stopnje tehnične podpore kot komercialna.

- Ker brezplačne programske opreme ni v domačem jeziku.

- Ker je na voljo manj možnosti izobraževanja za brezplačno programsko opremo.

- Ker pomoč za uporabo programa ni dostopna v domačem jeziku.

- Ker se z brezplačno programsko opremo večkrat namestijo reklamni programi.

\section{Splošna vprašanja}

11. Spol: M Ž

12. Navedite stopnjo študija:

- Študijski program 1. stopnje

- Študijski program 2. stopnje

13. Izberite državo prebivanja:

- Poljska

- Slovenija

- Srbija

- Velika Britanija 
Priloga 2: Kruskal-Wallisov test dejavnikov uporabe piratske programske opreme

\begin{tabular}{|c|c|c|c|c|}
\hline Trditev & Država preb. & (1) & (2) & (3) \\
\hline \multirow[t]{4}{*}{ Piratska Po brezplačna } & Slovenija & 58 & 102,21 & 0,070 \\
\hline & Velika Britanija & 45 & 82,48 & \\
\hline & Poljska & 59 & 104,92 & \\
\hline & Srbija & 38 & 112,37 & \\
\hline \multirow[t]{4}{*}{ Komercialna predraga } & Slovenija & 58 & 96,97 & 0,855 \\
\hline & Velika Britanija & 45 & 98,19 & \\
\hline & Poljska & 59 & 102,26 & \\
\hline & Srbija & 38 & 105,88 & \\
\hline \multirow[t]{4}{*}{ Enaka kakovost } & Slovenija & 58 & 99,01 & 0,550 \\
\hline & Velika Britanija & 45 & 92,90 & \\
\hline & Poljska & 59 & 101,39 & \\
\hline & Srbija & 38 & 110,39 & \\
\hline \multirow[t]{4}{*}{ Pravico imam, ker je na internetu } & Slovenija & 58 & 89,49 & 0,104 \\
\hline & Velika Britanija & 45 & 101,53 & \\
\hline & Poljska & 59 & 99,03 & \\
\hline & Srbija & 38 & 118,37 & \\
\hline \multirow[t]{4}{*}{ Ne povzročam škode nikomur } & Slovenija & 58 & 92,07 & 0,477 \\
\hline & Velika Britanija & 45 & 99,00 & \\
\hline & Poljska & 59 & 104,60 & \\
\hline & Srbija & 38 & 108,78 & \\
\hline \multirow[t]{4}{*}{ P PO je preprosto dostopna na $\mathrm{P} 2 \mathrm{P}$} & Slovenija & 58 & 101,09 & 0,576 \\
\hline & Velika Britanija & 45 & 90,91 & \\
\hline & Poljska & 59 & 102,89 & \\
\hline & Srbija & 38 & 107,25 & \\
\hline \multirow[t]{4}{*}{ Piratska PO javna, ker je na internetu } & Slovenija & 58 & 95,02 & 0,499 \\
\hline & Velika Britanija & 45 & 98,76 & \\
\hline & Poljska & 59 & 99,52 & \\
\hline & Srbija & 38 & 112,46 & \\
\hline
\end{tabular}

OP OM BE (1) število, (2) povprečni rangi, (3) stopnja značilnosti. 


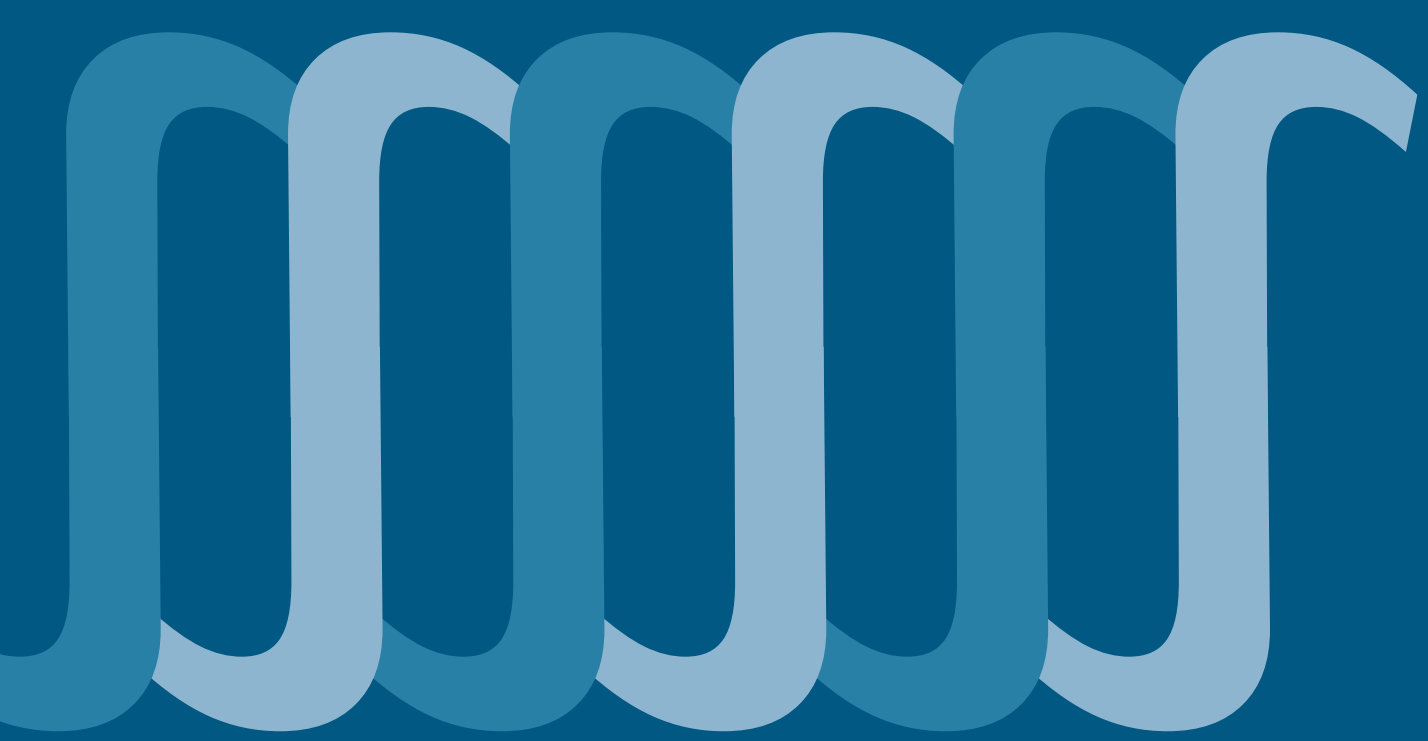

Založba Univerze na Primorskem www.hippocampus.si 